Three essays on food security, agricultural productivity, and commodity basis

A Dissertation
presented to

the Faculty of the Graduate School at the University of Missouri-Columbia

In Partial Fulfillment

of the Requirements for the Degree

Doctor of Philosophy

by
MOHAMMAD HASAN MOBAROK

Dr. Wyatt Thompson and Dr. Theodoros Skevas, Dissertation Supervisors

July 2021 
(C) Copyright by Mohammad Hasan Mobarok 2021

All Rights Reserved 
The undersigned, appointed by the dean of the Graduate School, have examined the dissertation entitled

\section{Three essays on food security, agricultural productivity, and commodity basis}

presented by Mohammad Hasan Mobarok,

a candidate for the degree of Doctor of Philosophy,

and hereby certify that, in their opinion, it is worthy of acceptance.

Professor Wyatt Thompson (co-chair)

Assistant Professor Theodoros Skevas (co-chair)

Professor Patrick Westhoff (member)

Associate Professor Mary Hendrickson (member) 


\section{ACKNOWLEDGEMENTS}

All praises to Allah, the creator, and the sustainer of the worlds, who blessed me with good physical and mental health to complete this journey. I seek his assistance, forgiveness, and guidance. I bear witness that no one is worthy of worship except Allah and that Muhammad is his final messenger.

My sincerest thanks to my advisors Dr. Wyatt Thompson and Dr. Theodoros Skevas, for their excellent supervision and guidance and for providing all the necessary opportunities that made my dream come true. I would like to thank my committee members, Dr. Patrick Westhoff and Dr. Mary Hendrickson, for their continuous support and guidance. I am thankful to the Food and Agricultural Policy Research Institute, University of Missouri Columbia (FAPRI-MU), for providing me a generous graduate research assistantship to complete my Ph.D. I am also grateful to my department colleagues and the Bangladeshi community here at Columbia, especially to Dr. Muhammad Muinul Islam, for the much-needed companionship and constant mental support. I am grateful to my elder brother Mohammad Hosne Mobarok and my parents for their continuous blessings and encouragement.

Finally, I am grateful to my wife, Dr. Tasnim Noor Peuly, for her continuous encouragement and love. 


\section{TABLE OF CONTENTS}

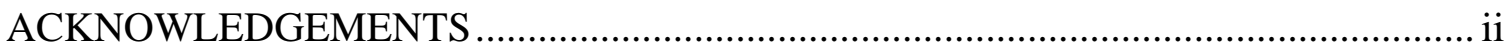

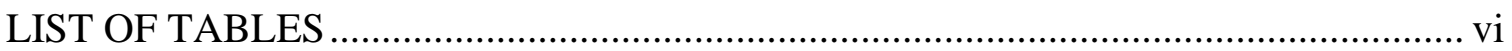

LIST OF FIGURES ….................................................................................... vii

ABSTRACT

\section{$\underline{\text { Essays }}$}

COVID-19 and policy impacts on the Bangladesh rice market and food security ..... 1

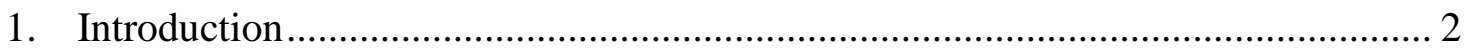

1.1. Literature review.................................................................................... 4

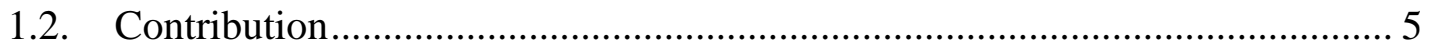

2. Food and trade policies of Bangladesh .......................................................... 6

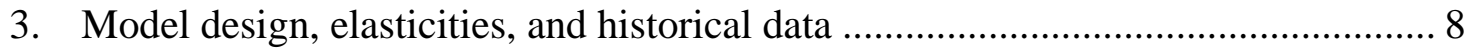

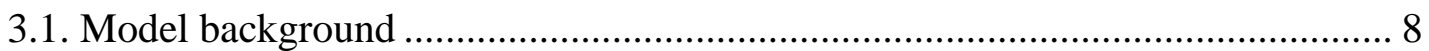

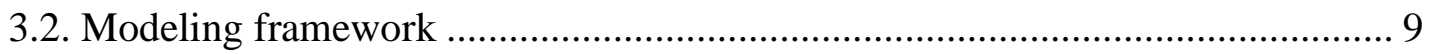

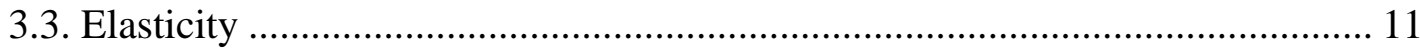

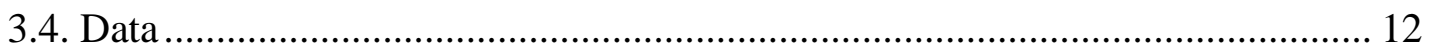

4. Food security indicators, exogenous assumptions, and scenarios ........................ 14

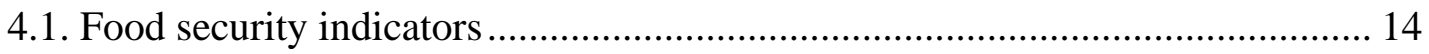

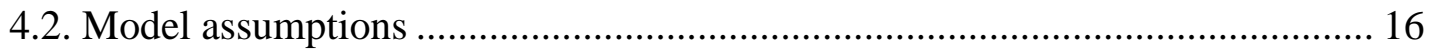

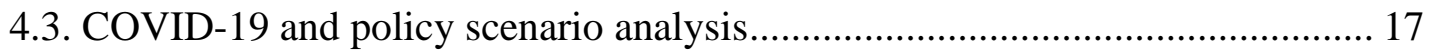

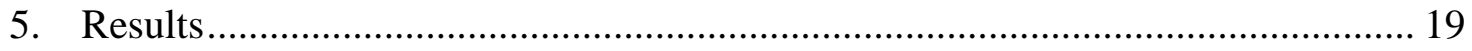

5.1. COVID-19 and Bangladesh's rice market ................................................... 19

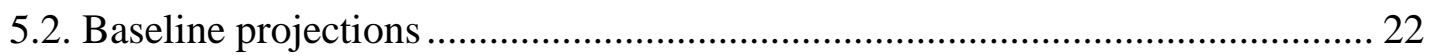




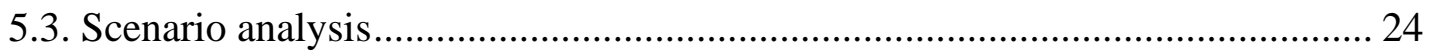

5.4. Pandemic, policies, and Bangladesh food security ………………….............. 28

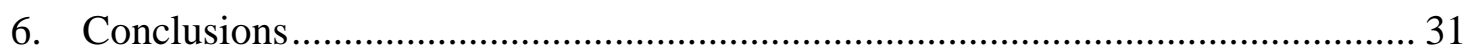

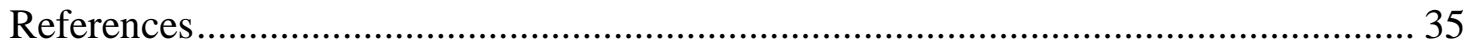

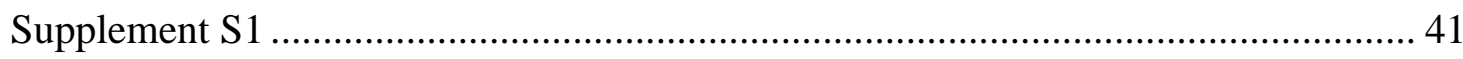

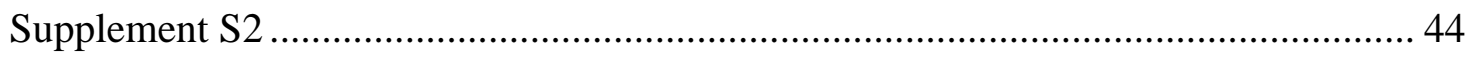

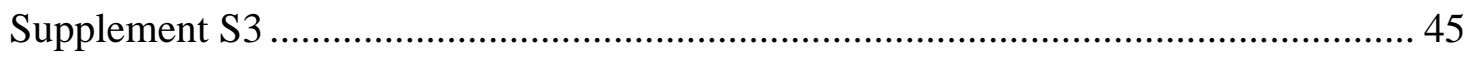

Women's empowerment in agriculture and productivity change: The case of Bangladesh rice farms ..................................................................................................... 47

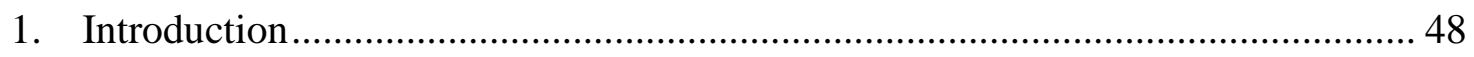

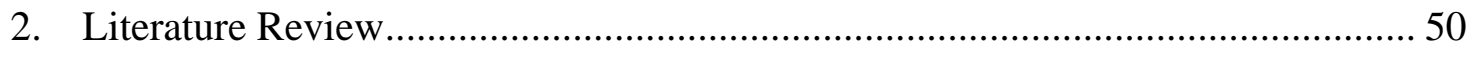

2.1. Productivity of Bangladesh agriculture …………............................................. 50

2.2. Women's empowerment and broader development issues ................................ 51

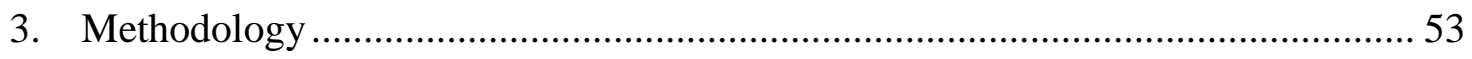

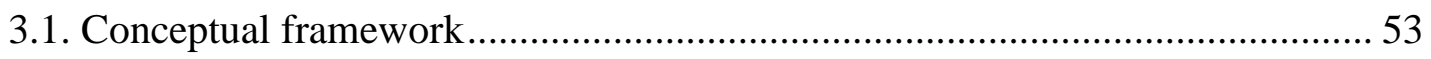

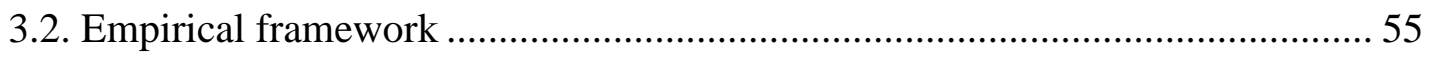

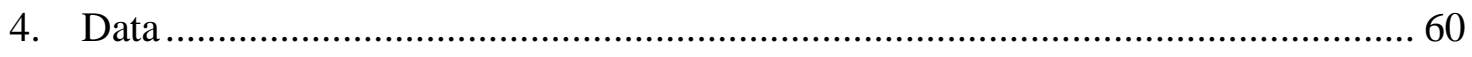

4.1. Women's empowerment in agriculture measures.............................................. 62

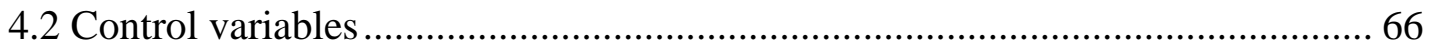

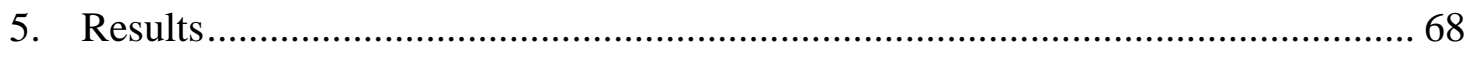

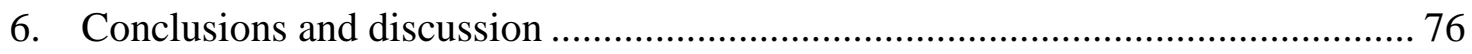

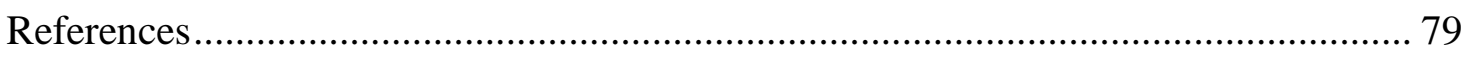

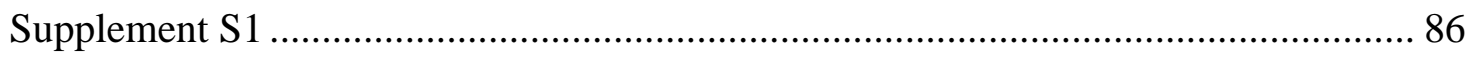

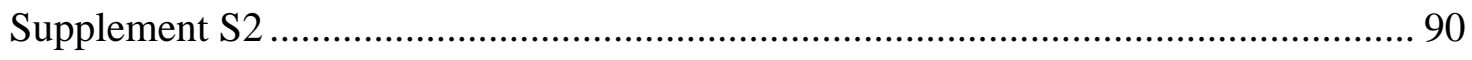


Supplement S3

Climate change-induced shifts in precipitation: response of Missouri corn and

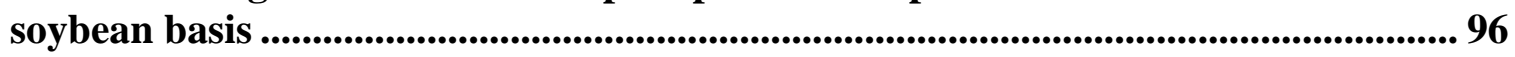

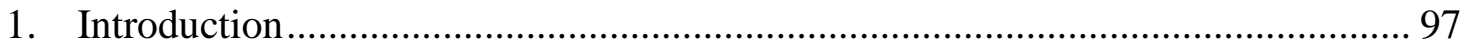

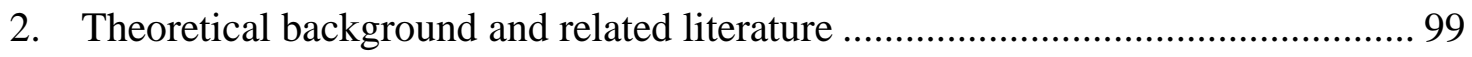

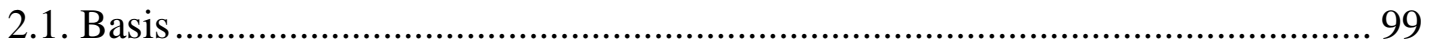

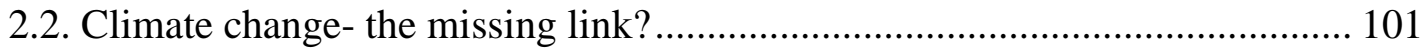

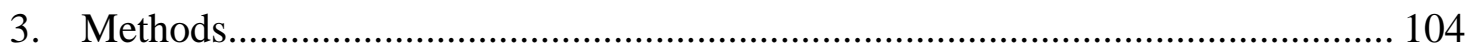

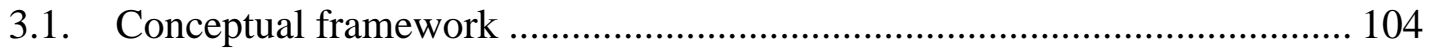

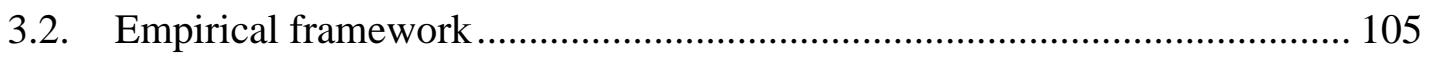

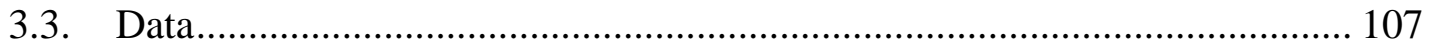

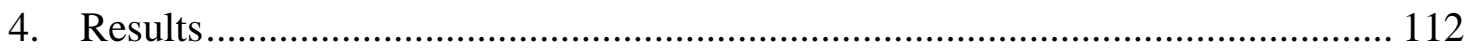

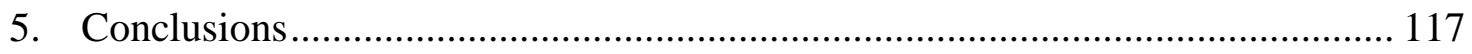

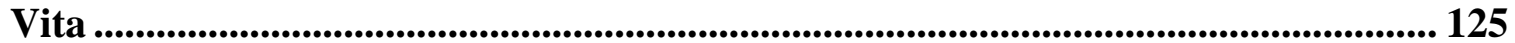




\section{LIST OF TABLES}

\section{COVID-19 and policy impacts on the Bangladesh rice market and food security}

Table 1.Elasticity estimates ................................................................................ 11

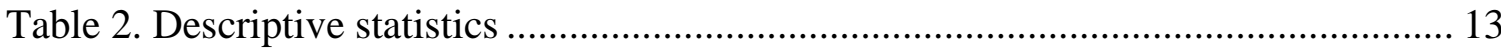

Table 3. Food security indicators........................................................................ 15

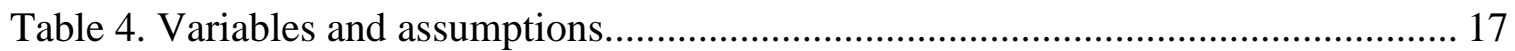

Table 5. Covid-19 impact ( $\%$ change relative to without-covid-19 baseline) ................. 19

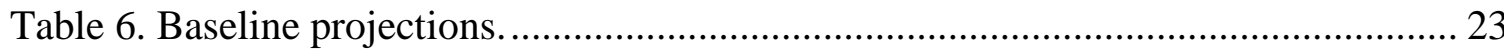

Table 7. Changes from baseline projections- higher import tariff................................ 24

Table 8. Changes from baseline projections- public stocks....................................... 25

Table 9. Changes from baseline projections- higher import tariff and public stocks....... 26

Table 10. Changes from baseline projections- yield gap closure ................................ 28

Table 11. Food security, hypothetical future pandemic, and policies- $\%$ change relative to

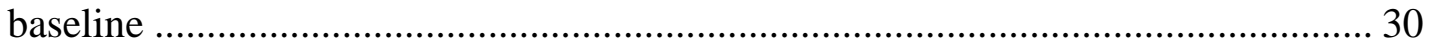

Supplement S2 Table 1. Augmented dickey-fuller test for unit root ............................. 44

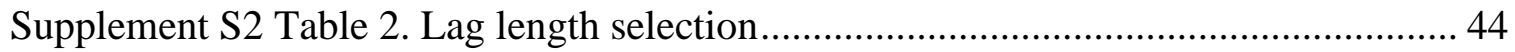

Supplement S2 Table 3. Co-integration test: bangladesh price \& thai 5\% parboiled price

Supplement S3 Table 1. Hypothetical future pandemic - no policy changes (\% change

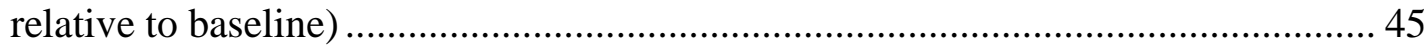

Supplement S3 Table 2. Hypothetical future pandemic- with pre-existing public stock

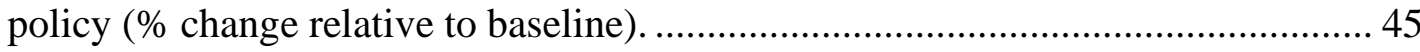

Supplement S3 Table 3. Impacts of a hypothetical future pandemic- with pre-existing yield gap closure policy ( $\%$ change relative to baseline)..................................... 46 


\section{Women's empowerment in agriculture and productivity change: The case of Bangladesh rice farms}

Table 1. Summary statistics of the deflated outputs and inputs of the sample households

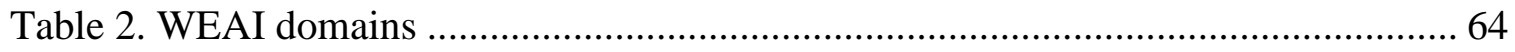

Table 3. Summary statistics of weai and alternative empowerment measures ................ 65

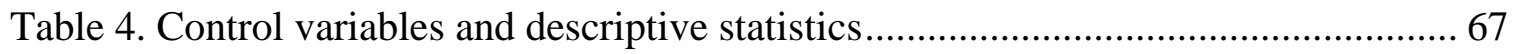

Table 5. Average Malmquist productivity index and its components of the sample

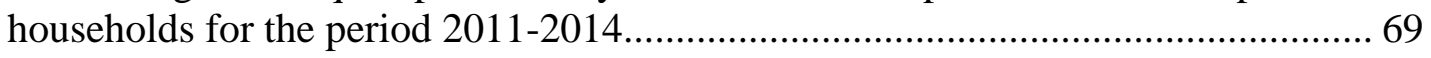

Table 6. Results of the OLS bootstrap regression of the determinants of farm productivity change and its components ........................................................................ 70

Table 7. Results of the OLS bootstrap regression of the determinants of farm productivity change and its components (empowerment gap) ............................................... 72

Table 8. Results of the OLS bootstrap regression of the determinants of farm productivity change and its components (WEAI domains) ...................................................... 74

Table 9. Results of the OLS bootstrap regression of the determinants of farm productivity change and its components (production domain indicators) ................................ 75

Supplement S1 Table 1. Empowerment assumptions.............................................. 88

Supplement S3 Table 1. Results of the OLS bootstrap regression of the determinants of farm productivity change and its components (empowerment gap)...................... 92

Supplement S3 Table 2. Results of the OLS bootstrap regression of the determinants of farm productivity change and its components (weai domains).............................. 93

Supplement S3 Table 3. Results of the OLS bootstrap regression of the determinants of farm productivity change and its components (production domain indicators)........ 94

Climate change-induced shifts in precipitation: response of Missouri corn and soybean basis

Table 1. Descriptive statistics of the study variables.............................................. 111

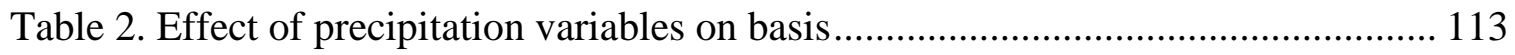




\section{LIST OF FIGURES}

COVID-19 and policy impacts on the Bangladesh rice market and food security

Figure 1. Model framework: import parity ........................................................ 10

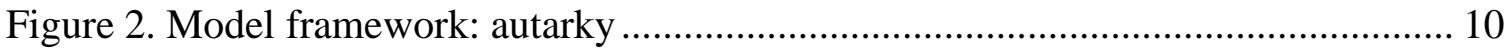

Climate change-induced shifts in precipitation: response of Missouri corn and soybean basis

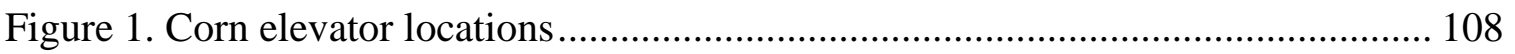

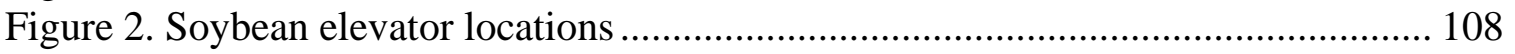

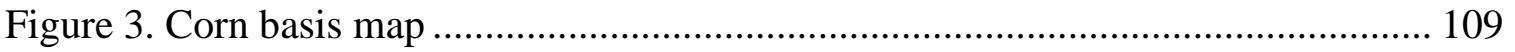

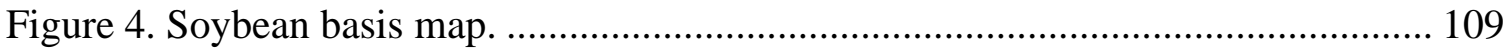

Figure 5. Local precipitation map- weather stations around corn elevators ................... 110

Figure 6. Local precipitation map- weather stations around soybean elevators ............. 110 


\title{
ABSTRACT \\ THREE ESSAYS ON FOOD SECURITY, AGRICULTURAL PRODUCTIVITY, AND COMMODITY BASIS
}

\author{
Mohammad Hasan Mobarok
}

Dr. Wyatt Thompson and Dr. Theodoros Skevas, Dissertation Supervisors

The proposed research is constructed around the theme of food security, agricultural productivity, and commodity basis. The first paper analyzes the impacts of COVID-19 on the Bangladesh rice market within the framework of a partial equilibrium regime-switching model. We provide an initial estimate of the short- and long-run effects of COVID-19 on the Bangladesh rice market and food security sustainability by comparing baseline projections. We analyze the effect of shocks in policies related to trade, public stock, and productivity on rice supply, demand, and food security dimensions. Finally, we assess the effectiveness of these policies to smooth out shocks that may arise from a future pandemic like COVID-19. In the second essay, we analyze the relationship between women's empowerment in agriculture and Bangladesh rice farm productivity change and its components, which include efficiency change, technological change, and scale efficiency change. We employ the non-parametric Malmquist approach and bootstrap regression method. We find that improvements in women's empowerment in agriculture, specifically enhancing their ability to make independent choices regarding agricultural production, have a statistically significant positive association with productivity change, efficiency change, and technical change. We also find that lowering the gender parity gap is positively related to improving the productivity of the sample farms. In the third essay, we analyze the effect of precipitation variations, namely local, growing season, and 
regional precipitation, on Missouri corn and soybean basis. We document statistically significant linear and nonlinear basis responses in corn and soybean models for local and growing season precipitation variations. We also find a statistically significant moderating effect of port distance measure on the curvilinearity of the association between regional precipitation and soybean basis.

Keywords: food security; policy analysis; women's empowerment; Malmquist; basis; corn; soybean; climate change; precipitation 


\title{
Essay 1: COVID-19 and policy impacts on the Bangladesh rice market and food security
}

\begin{abstract}
:
This research employs a partial equilibrium model to estimate the short- and longrun effects of COVID-19 and rice policies on Bangladesh's rice market and food security. We also analyze the impact of relevant policies in terms of their effectiveness in mitigating stresses stemming from a hypothetical pandemic with a COVID-19-like impact. The results indicate that the effect of COVID-19 on Bangladeshi food security during FY 2019/20 was mixed, as the indicators of food availability improved by $5 \%$, and decreased by $17 \%$ for food stability, relative to what they would have been otherwise. Policy simulation results indicate that a higher import tariff improves self-sufficiency status but undermines rice availability and accessibility by bending the market toward a restrictive trade regime. Results also indicate that, unlike stock enhancement policy, closing the existing yield gap improves rice availability, accessibility, and moderates the depressing effect of a future event with repercussions similar to COVID-19, although the yield policy appears more speculative and could be too costly. The insights generated contribute to the understanding of policies that aim to achieve sustainable development goals related to aggregate food security, and build resilience against future shocks akin to COVID-19. Keywords: Bangladesh, COVID-19, food security, partial equilibrium, rice
\end{abstract}




\section{Introduction}

There have been numerous studies on the concept of food security. Food security is relevant to the global policy agenda because of concern over issues such as growing population, rising production costs, declining agricultural production, and climate change $[1,2]$. Improved food security is also viewed as the key to achieving the sustainable development goal (SDG) [3]. Attention on food security was heightened after the global food price crisis of 2006-08, which pushed an additional 130 to 155 million people into poverty in 2008, and triggered riots in more than two dozen countries, including Bangladesh [4,5]. Similarly to the food price crisis of 2006-08, the COVID-19 pandemic could have a detrimental effect on food security. Containment measures such as lockdowns and social distancing imposed by governments around the globe to slow down the pandemic have amplified the risks of food insecurity directly through supply chain disruptions, and indirectly through decreases in purchasing power due to negative income shocks [6-8]. According to WFP [9], by the end of 2021 an additional 121 million people will be pushed into acute food insecurity due to the economic fallout of the pandemic. Bangladesh implemented a series of mitigation strategies to contain the pandemic, and the economic slump and supply chain disruptions triggered by such measures could have detrimental effects on agricultural production, trade, and price volatility. Rice availability, accessibility, and stability in Bangladesh could be affected, at least in the short run. Moreover, the current crisis seems unlikely to help Bangladeshi policymakers meet their stated objectives to increase food security and to achieve a transition toward sustainable development targets under the SDG agenda. 
Our objective in this paper is to inform policy decisions relating to the Bangladesh rice market and food security indicators, and to conduct a COVID-19 impact analysis by comparing the baseline projections generated using pre-and post-COVID-19 exogenous macroeconomic, policy, and trade data. We also test the impact of different policy scenarios on the Bangladesh rice market, as well as the state of Bangladesh's food security during a hypothetical future pandemic after these policy options have been put in place. We do so by developing a partial equilibrium, structural-based model that incorporates Bangladesh's food and trade policies.

Despite the evidence of adverse effects from the food price increase, spikes, and income shocks on poverty and food security, little has been done to provide a long-term outlook on the food security status of Bangladesh [10-14]. To date, there have been insufficient efforts to examine the effects of food or trade policy changes or exogenous shocks on the Bangladeshi food market's fundamentals. The need for such analysis is even more compelling as the effects of the COVID-19 pandemic are likely to spill over into longer-run food security via income and food price impacts. In Bangladesh, food accounts for about $70 \%$ of total expenditures for the poor, defined as the bottom quintile of the income distribution, and the poor spend at least 35\% of their income on staple foods [15]. Rice is the staple food of Bangladesh, which provides two-thirds of the calorie needs and half the protein consumption of the nation [16]. The rice sector is one of the key targets of the Government of Bangladesh's (GoB) food policy to ensure food security for all people at all times [17]. COVID-19 has the potential to jeopardize food security as it has already caused disruptions in food production, value chain, and access [18-20]. Therefore, estimates of the impact of COVID-19, future events with a COVID-19-like effect, and food 
and trade policies on Bangladesh food security seem likely to be of relevance to the policymakers. If so, then there is a need for estimates of such effects to help policymakers formulate better policy responses toward the current and potential impact of COVID-19 on Bangladesh food security and to maintain rice market stability in the face of any future disruptions.

\subsection{Literature review}

Previous studies provided limited retrospective and prospective insights into the rice market and related food security concerns of Bangladesh. For example, Del Ninno et al. [21] analyzed the impact of the 1998 flood on Bangladesh's food security at national and household levels, and provided policy implications for managing future natural disasters in developing countries. Chen and Lu [22] measured the food security index (FSI) level changes in Bangladesh, and analyzed the contributions of factors such as total population, total cropping area, mean crop yield, and per capita consumption of rice and rice equivalents on FSI change during 1990-2013. Some studies provided projections for the Bangladesh rice market, and simulated supply and demand balance for rice under alternative scenarios [23-26]. There are studies that analyzed public stock requirement for stabilizing prices and mitigating future supply disruptions $[27,28]$. One common limitation of these studies is the omission of certain macroeconomic variables and trade policies (e.g., GDP, exchange rate, import tariff) in analyzing the rice market and food security. However, they do not explicitly employ any analytical tools that can capture the effect of shocks related to future events and policy changes on aggregate food security dimensions. Moreover, older studies might not relate well to the impacts of the COVID-19 pandemic, despite its potentially large impacts including at the intersection of food consumption and 
online shopping [29,30], business innovation [31], working environments [32], agricultural and food markets, and trade more generally $[33,34]$.

The partial equilibrium model developed in this study for the Bangladeshi rice market can fill this gap, as it quantifies the impact of a pandemic and certain policy options on key food security indicators. Although we found no studies of current Bangladeshi rice policy and food security that use the method employed here, several studies used a partial equilibrium framework to analyze and quantify agricultural and trade policies, examining their impact on different agricultural commodities in other parts of the world. Fathelrahman et al. [35] used a partial equilibrium framework to measure the welfare effect of food trade liberalization in India, Egypt, Pakistan, Saudi Arabia, and the United Arab Emirates (UAE). Others examined the effects of trade and agricultural policies on the rice sector in Madagascar [36], Japan [37], and Thailand [38]. Partial equilibrium models have also been used to estimate the effect of water subsidy policy on Banana farming in Jordan [39] and to analyze the effect of trade liberalization in the world wheat market on US wheat export demand elasticity [40]. Moreover, there are studies that simultaneously examined the impact of alternative policy responses on the Japanese and Indian rice and wheat markets $[41,42]$.

\subsection{Contribution}

To the best of our knowledge, this research makes several unique contributions to the existing literature. First, this is a pioneering study in estimating the ex-post and ex-ante effects of COVID-19 on Bangladesh's rice market and food security using the partial equilibrium technique. Second, this is the first study to address the possibility of a trade regime switch in analyzing Bangladesh's rice market and related policies within a partial 
equilibrium framework. There is evidence that the Bangladeshi rice market sporadically shifts between autarky and import parity regime $[16,28]$. Hence, the trade regime-switching mechanism employed in this research is more accurate in that it addresses the possibility of changing price formation under different market and policy conditions. Finally, we also evaluate the effectiveness of existing policies to cope with shocks that may stem from future events like COVID-19. The findings from this study will provide policymakers quantified insights regarding the current pandemic and help them to understand the potential effect of future pandemics on Bangladesh's rice market and the sustainability of food security.

\section{Food and trade policies of Bangladesh}

The current food policy framework in Bangladesh includes producer-oriented (e.g., public food stocks), consumer-oriented (e.g., public food grain distribution system), and trade and market-oriented (e.g., import tariff) policies whose stated purposes include ensuring an adequate and stable supply of food [43]. The current policy environment interlaces rice and food security policy, as discussed in this section, previewing our use of three policy instruments: import tariff, public stock, and yield gap closure. These are used to assess the impact of external shocks and variations on the dimensions of food security of Bangladesh.

The initial trade liberalization process in Bangladesh was started in the early 1980s with a new industrial policy in 1982. Major trade reforms were started in 1991, with the elimination of non-tariff import restrictions on most of the agricultural products and with the legalization of rice import by the private sector in 1994. Since then, governments have used import tariffs as a crucial policy instrument to develop the domestic rice market, 
stabilize prices, and provide price incentives to producers and consumers. For example, to cover the production losses caused by the 1998 flood, the government removed import tariffs to encourage private sector import to avoid a food supply shortage. Such short-term policy action, along with the prompt port clearance, prevented domestic market price from rising above import parity level price. Del Ninno et al. [44] stated that such initiatives allowed the private sector to import a substantial amount of rice and proved to be less costly compared to the production shortfall following the 1988 flood, which was mainly handled through government commercial imports. We had observed similar policy actions following the 2004 monsoon flood and the 2007/08 world food crisis when the government quickly reduced rice import tariffs from $23 \%$ and $5 \%$ to $8 \%$ and $0 \%$, respectively. At the end of the financial year (FY) 2018/19, the government nearly doubled (from 28\% to 55\%) import tariff to boost producer price after rice production hit an all-time high of 36 million metric tons (mmt) in FY 2017/18. Such flexibility in trade policies is also perceived as useful from a food security perspective, and there are certainly important implications. For example, studies indicate that Madagascar's 2004 rice crisis was aggravated by the government's reluctance to lower import tariff rates $[45,46]$.

Public food grain stock policy is another instrument that is intended to help maintain food security. Due to the inelasticity of food grain demand in the short run, even a small disruption in food grain output can cause massive fluctuation in the market price without the ready availability of government buffer stocks for price stabilization $[47,48]$, at least in the absence of private stocks and fully liberalized trade. Under the current public stock policy, GoB seeks to stabilize food grain prices by responding to both positive and negative supply disturbances through food grain purchases and sales [49]. Goletti [50] 
stated that such interventions by the government influence market expectations about price. Del Ninno et al. [44] stated that despite smaller production shortfalls, the rise in nominal rice price was much bigger after the 1974 flood compared to the 1988 and 1998 floods as the government's ability to intervene in the domestic market was hampered by low public stock. Currently, GoB mandates maintaining a minimum public stock of $1 \mathrm{mmt}$ of food grain to smooth out price volatility associated with supply disturbance and handle emergency offtake requirements [49].

Godfray et al. [51] stated that low yield results from a lack of technical knowledge, skills, or from constraints that limit investment in productivity-enhancing measures. Achieving yield improvements that close the gap between realized yield and the best possible yield is proposed by some as a factor that would contribute to improved food security [52]. The feasibility of such yield improvements and the cost of significant steps in this direction is unknown. For example, since the scope for production growth through area expansion is very limited, GoB has focused on improving current yield status through the adoption of the System of Rice Intensification (SRI), which involves better management of plants, soil, water, and nutrients [53]. Although important, we are not aware of any study that relates exact yield increase estimates and costs for this program.

\section{Model design, elasticities, and historical data}

\subsection{Model background}

Since the trade liberalization in 1994, Bangladesh has consistently imported rice from the world market, as represented by the Thai export price. Such persistent trade indicates that changes in the world price might be transmitted to the domestic rice price through spatial arbitrage. Dorosh and Rashid [28] found evidence of long-run transmission 
from the subsidized below-poverty-line price of India to the domestic price during 20022007. Following Dorosh and Rashid [28], we employ the co-integration method to examine the spatial price linkage between Bangladesh domestic price and external price. We update the model with additional monthly data ranging from January 2000 to October 2020 and world reference price (Thailand free on board 5\% broken rice). Our findings indicate that there exist at least two co-integrating relationships between Bangladesh and world price, implying a long-run equilibrium relationship (see supplement S2). However, the increase in the import tariff from $28 \%$ to $55 \%$ in FY 2019/20 proved to be high enough to eliminate import almost entirely. This indicates that such a tariff level can influence the correlation between domestic and world price and cause the Bangladesh rice market to be autarkic. Since the Bangladeshi rice market can switch between imports with tariff and autarky, it is important to utilize a partial equilibrium approach that can capture the equilibrium pricing conditions under different trade regimes. Therefore, we employ a partial equilibrium model that solves for market equilibrium price under import and autarky regimes.

\subsection{Modeling framework}

The model developed here is a multi-equation partial equilibrium model and is divided into three blocks, namely: supply, demand, and price linkage. The blocks contain behavioral equations that are estimated based on the economic and production dynamics of the Bangladesh rice market, although key elasticities are drawn from the relevant literature (see supplement S1). Total domestic rice supply consists of production and beginning stocks. Production is estimated by multiplying total area planted and yield. Total rice demand of Bangladesh is determined by domestic demand, seed, feed, and wastage, ending stock, and export supply. In this study, we divided net domestic demand (domestic 
demand minus seed, feed, and wastage) by the total population to obtain the per capita net domestic demand for rice. In the price linkage block, separate trade and price equations for different market regimes are estimated to formalize the relationship between world market prices, trade, and domestic prices.

Figures 1 and 2 depict the flow of the Bangladeshi rice market model's essential components with and without trade, respectively.

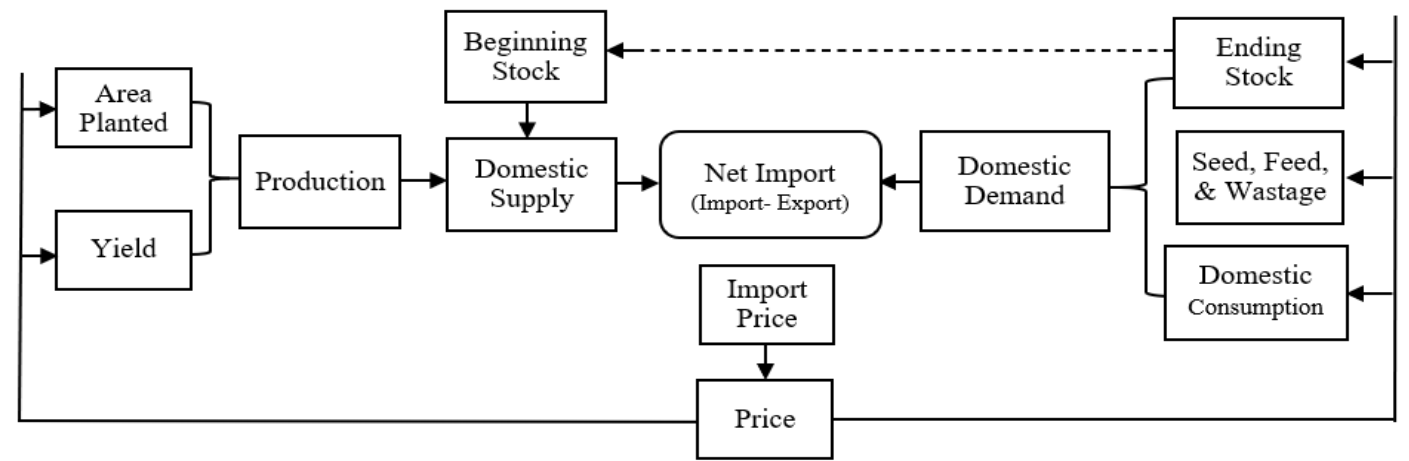

Figure 1. Model framework: import parity

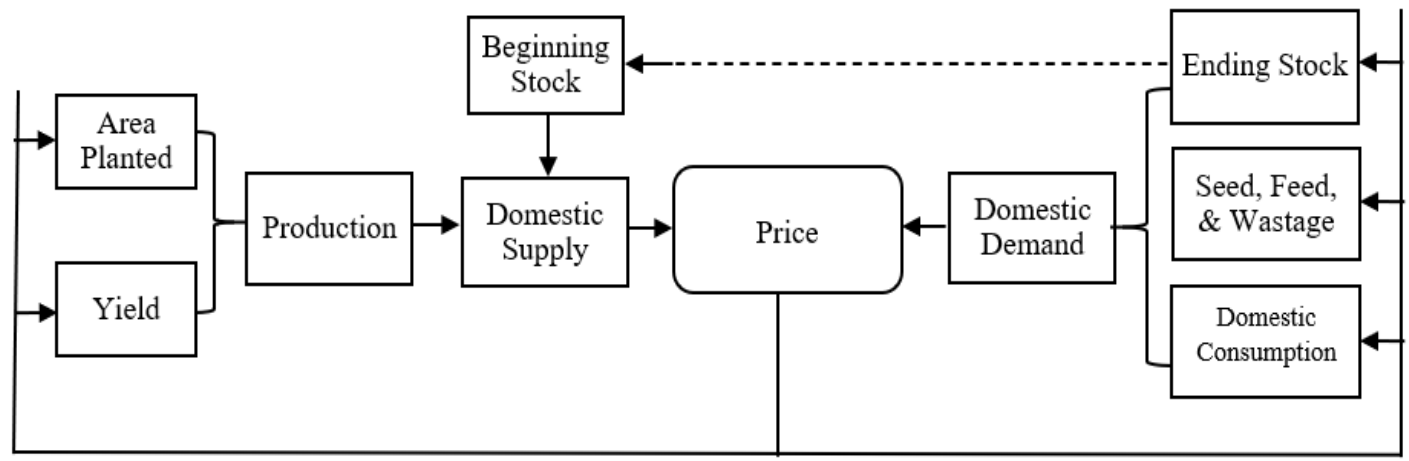

Figure 2. Model framework: autarky

Under autarky, the model uses a price equilibrator framework to simulate equilibrium price through setting demand equal to supply. Unlike autarky, domestic price in import parity regime is determined by the world market price with the tariff and imports clear the market. The switching mechanism used in this model is triggered by the price levels and allows the model closure to switch between autarky and import parity. For example, the model switches to autarky when the import parity price stays above the 
autarky price. Similarly, the model closes on net trade and switches to import parity when the import parity price is less than the autarky price.

\subsection{Elasticity}

The price and income elasticities of rice have not been estimated here; instead, they are borrowed from the existing literature. Table 1 reports elasticity estimates available in the relevant literature. As a rule, rice demand and supply are found to be inelastic with respect to rice price and income. Demand elasticities range fairly narrowly from -0.30 to -0.89 , and supply elasticities run from 0.20 to 0.50 . Income elasticities of rice demand are all positive in this literature, with values no lower than 0.30 and as high as 0.68 , suggesting a fairly uniform view that this is normal, but a necessity with decreasing budget share as income rises.

Table 1. Elasticity estimates

\begin{tabular}{lllll}
\hline Author & Data type & $\begin{array}{l}\text { Demand } \\
\text { elasticity }\end{array}$ & $\begin{array}{l}\text { Supply } \\
\text { elasticity }\end{array}$ & $\begin{array}{l}\text { Income } \\
\text { elasticity }\end{array}$ \\
\hline Hasan [54] & Survey & & 0.30 & 0.40 to 0.60 \\
Hossain and Yunus [26] & Survey & -0.59 to -0.68 & 0.36 to 0.43 \\
Dorosh and Rashid [28] & Literature survey & -0.30 to -0.50 & 0.20 to 0.30 & 0.30 to 0.50 \\
World Bank [55] & Literature survey & -0.55 to -0.89 & 0.30 to 0.50 & 0.51 to 0.64 \\
Del Ninno et al. [44] & Market & -0.45 & 0.35 \\
Brennan [56] & Market & -0.50 & 0.40 & \\
Ahmed and Shams [57] & Survey & -0.45 & & 0.68 \\
\hline
\end{tabular}

Source: Authors

For this study, we use a value of -0.50 for demand own-price elasticity, 0.30 for supply elasticity with respect to rice returns per acre, and 0.40 for income elasticity of demand. Real price, returns, and income are used. These values correspond to the elasticities found in the literature, with greater weight given to studies that are more recent. 


\subsection{Data}

To study the Bangladeshi rice market, we use national level and yearly data from various sources. The historical period used in this research is FY 1995/96 to FY 2019/20.This period is considered to provide an adequate number of observations that are representative of current market conditions, because the liberalization of agricultural imports in Bangladesh started in 1990, and import procedures were deregulated in 1994. Table 2 presents descriptive statistics for key supply and demand variables. The time series data used in the analysis may not possess constant mean due to the deterministic trend. Therefore, to remove the effect of factors such as technology, market and trade policies, we detrend the data by regressing each variable on constant and a trend variable and obtain the time trend removed residuals. 


\section{Table 2. Descriptive statistics}

\begin{tabular}{|c|c|c|c|c|c|}
\hline \multicolumn{6}{|l|}{ Descriptive statistics } \\
\hline Variable & Unit & Mean & Std. Dev & Min & Max \\
\hline Area planted & thousand acres & 27,041 & 1349 & 24,567 & 29,388 \\
\hline Yield & ton/acre & 1.06 & 0.18 & 0.72 & 1.32 \\
\hline Production & thousand metric ton & 28833 & 6245 & 17687 & 38724 \\
\hline Net domestic demand & thousand metric ton & 26475 & 5258 & 16824 & 34970 \\
\hline Imports & thousand metric ton & 903 & 968 & 4 & 3889 \\
\hline Seed, feed and wastage & thousand metric ton & 3237 & 953 & 1769 & 4647 \\
\hline Ending stocks & thousand metric ton & 627 & 266 & 123 & 1256 \\
\hline Price & $\mathrm{BDT}^{*} /$ metric ton & 20,953 & 8435 & 9820 & 37,570 \\
\hline Thailand $5 \%$ parboiled price & USD/metric ton & 375 & 134 & 187 & 616 \\
\hline \multicolumn{6}{|c|}{ Descriptive statistics after detrending } \\
\hline Area planted & thousand acres & 0.00 & 629 & -1328 & 1037 \\
\hline Yield & ton/acre & 0.00 & 0.04 & -0.07 & 0.05 \\
\hline Production & thousand metric ton & 0.00 & 1287 & -2503 & 2217 \\
\hline Net domestic demand & thousand metric ton & 0.00 & 1213 & -2521 & 2365 \\
\hline Imports & thousand metric ton & 0.00 & 965 & -974 & 3082 \\
\hline Seed, feed and wastage & thousand metric ton & 0.00 & 235 & -380 & 411 \\
\hline Ending stocks & thousand metric ton & 0.00 & 239 & -647 & 454 \\
\hline Price & $\mathrm{BDT}^{*} /$ metric ton & 0.00 & 3086 & -5316 & 5951 \\
\hline Thailand $5 \%$ parboiled price & USD/metric ton & 0.00 & 111 & -134 & 230 \\
\hline
\end{tabular}

Source: Authors' calculation

Note: *Bangladeshi Taka

Imports appear the most volatile component of supply if assessed by comparing the standard deviation to the mean, or comparing maximum and minimum values. However, domestic production is many times higher than imports, as implied by the product of mean area and mean yield. Although area and yield both vary, if assessed by the standard deviations, the ranges seem small as compared to the mean values. Most production and imports go to food use, but a share is assumed in the government statistics to go to seed and feed uses or waste. Demand-side variability is a mirror of domestic production because, although ending stocks could in principle moderate the impact of supply shocks on domestic use, the mean stock level represents a small share of the market quantities in 
historical data. The ranges of prices, both domestic and border, have been substantial in this period.

Market data, including production, area planted, yield, imports, feed and residual, ending stock, world market price (Thailand 5\% parboiled rice price), and exports, were collected from the Food Planning and Monitoring Unit (FPMU) of the Ministry of Food of Bangladesh Government. Historical GDP, exchange rate, consumer price index, and population data were collected from the World Bank. Policy data, certainly including the import tariff rate, were collected from the Bangladesh Ministry of Agriculture, the International Fertilizer Development Center [58], and the World Trade Organization's Tariff Analysis Online database, respectively.

\section{Food security indicators, exogenous assumptions, and scenarios}

\subsection{Food security indicators}

Food security is a broad term that includes both macro dimensions, such as price stability that ensures availability and access to food, and micro dimensions that allow individuals to produce or purchase food according to their dietary preferences. Our approach is focused on the macro dimensions of Bangladesh's food security, and thereby relevant to policymakers who consider the implications of their strategies for aggregate rice demand, supply, and price in terms of their food security implications. Thompson et al. [59] analyzed food security characteristics of developing countries using the macro food security dimensions, namely availability, stability, and accessibility. One concern is that the macro approach does not necessarily capture the underlying dynamics of food security between and within households. Nonetheless, macro analysis of food security is still crucial in that insufficient per capita food availability would affect the market price and, thereby, 
food access at the individual level [60]. Therefore, we measure the implications of market shocks for availability, stability, and accessibility dimensions of Bangladesh food security. GoB's national food policy plan of action also articulated food availability, supply stability, and access as core food security objectives [49].

Quantitative measures of the availability, accessibility, and stability dimension of food security that respond to markets, and more specifically to policy impacts on markets, require indicators. Ideally, each indicator reflects the characteristics of a specific dimension, and together a set of such indicators can provide an unbiased assessment of the impacts of policy options on food security. There are no definitive measures of food security dimensions. Thus, our proposed measures (Table 3) are developed based on the definition of these dimensions, variables widely used to represent market conditions, and previous studies that developed the framework for indicators of food security dimensions.

\section{Table 3. Food security indicators}

\begin{tabular}{ll}
\hline Dimension & Indicators \\
\hline Availability & Per capita consumption ratio \\
Accessibility & Real price ratio \\
Stability & Self-sufficiency ratio, stocks-to-consumption ratio \\
\hline Source: Authors &
\end{tabular}

We use the per capita consumption ratio, a comparative indicator which measures the deviation of projection year per capita rice consumption from the base periods (FY 2017/18 to FY 2019/20) mean per capita consumption, for an indicator of availability [59]. Per capita income is a useful measure for the accessibility or economic affordability of food. Since GDP is exogenous to the model and no shocks are planned on this variable, we have not used per capita GDP as an indicator of accessibility despite its appropriateness. As an alternative, we use the ratio of projection year average real price relative to the 
average real price in the base period (FY 2018/19 to FY 2019/20) as a measure of accessibility as price relates to consumer's food accessibility. We use the self-sufficiency ratio and stocks-to-consumption ratio as measures of stability [59]. The self-sufficiency ratio is the ratio of domestic production relative to the available supply. The stocks-toconsumption ratio is an indicator of supply buffer by expressing what part of needs at going prices could be met through stock release in the event of a production or import shock. These indicators do not support conclusive statements about food security outcomes, however. For example, having large public stocks might be less effective in reducing price shocks under import parity regime as compared to the case of autarky regime. Once sufficiently built, the government can use the stock to check the domestic price from rising during the period of scarcity, but this requires additional policy decision making regarding stock release. Similarly, the scope for self-sufficiency to reflect stability of food depends on the sources of shocks to supply, in particular whether domestic or foreign shocks are more important.

\subsection{Model assumptions}

Variables and assumptions used in the model include GDP growth to back-calculate nominal GDP level, yearly population growth, consumer price index (CPI) inflation (Bangladesh and the U.S.), and Thailand free on board (FOB) 5\% broken rice (Table 4). 
Table 4. Variables and assumptions

\begin{tabular}{|c|c|c|}
\hline Variable & With-COVID Simulation & Without-COVID Simulation \\
\hline Real GDP growth & $\begin{array}{l}\text { 1.6\% FY } 2020 / 21 \text { and } 1 \% \text { in FY } \\
2021 / 22\end{array}$ & $\begin{array}{l}7.8 \% \text { in FY } 2019 / 20 \text { and } 7.4 \% \text { from } \\
\text { FY 2020/21 onward }\end{array}$ \\
\hline $\begin{array}{l}\text { Population } \\
\text { projections }\end{array}$ & UN's medium variant projections & Same as with-COVID model \\
\hline CPI Bangladesh & $\begin{array}{l}5.7 \% \text { in FY } 2020 / 21 \text { and } 5.6 \% \text { from } \\
\text { FY } 2021 / 22 \text { onwards }\end{array}$ & $5.5 \%$ from FY 2019/20 onwards \\
\hline CPI U.S. & $\begin{array}{l}0.6 \% \text { in FY } 2020 / 21 \text { and } 2.2 \% \text { from } \\
\text { FY } 2021 / 22 \text { onwards }\end{array}$ & $\begin{array}{l}2.2 \% \text { in FY } 2019 / 20 \text { and } 2.3 \% \text { from } \\
\text { FY } 2020 / 21 \text { onwards }\end{array}$ \\
\hline Exchange rate & $\begin{array}{l}\text { Constructed based on the difference } \\
\text { between Bangladesh and the U.S. } \\
\text { consumer price }\end{array}$ & Same as with-COVID model \\
\hline World price & $\begin{array}{l}\text { Thailand 5\% FOB Bangkok; forecasts } \\
\text { are taken from World Bank's } \\
\text { commodity markets outlook, April } \\
2020\end{array}$ & $\begin{array}{l}\text { Thailand 5\% FOB Bangkok; } \\
\text { forecasts are taken from World } \\
\text { Bank's commodity markets outlook, } \\
\text { October } 2019\end{array}$ \\
\hline Import tariff & $55 \%$ from FY 2021/22 onward & Same as with-COVID model \\
\hline Fertilizer subsidy & $\begin{array}{l}\text { Moving average of past three years } \\
\text { subsidy per ton }\end{array}$ & Same as with-COVID model \\
\hline
\end{tabular}

\subsection{COVID-19 and policy scenario analysis}

In this section, we explain the assumptions and mechanisms used to analyze the impact of COVID-19 and the current policy environment on the Bangladesh rice market and food security.

COVID-19: To estimate the effect of COVID-19, we compare with- and withoutCOVID-19 results. Holding all else constant, we generate different baseline values by changing macroeconomic projections and world price to reflect the changing conditions caused by the pandemic. We do this by replacing projections (estimated by the World Bank and IMF as of October 2020) with forecasts made in January 2020 and October 2019. We assume that the changes in World Bank projections of the world rice price were dominated by COVID-19. However, changes after the first few years might reflect other factors, such as changes in long-run expectations of global productivity or demand growth, not COVID- 
19. Indeed, the World Bank updated projections suggest a higher long-run price that could be a residual effect of COVID-19 but might be caused by other factors as well. Nevertheless, we use these projected world rice prices directly here.

Scenario 1- Import tariff: This scenario explores one mechanism that might be suggested by the self-sufficiency goal of the Seventh Five Year Plan (2016-2020) of the Bangladesh government [68], namely, increasing the import tariff to a level that eliminates arbitrage between domestic and world prices. At this tariff, import becomes nonexistent. In our policy experiment, we raise the current $55 \%$ import tariff to $90 \%$; a rate that is not beyond the realm of possibility given past values, yet high enough to make import unfeasible.

Scenario 2- Public stocks: As of FY 2019/20, the public food grain storage capacity of Bangladesh stands at $2.3 \mathrm{mmt}$, and the GoB has a target of expanding public storage capacity to $3 \mathrm{mmt}$ [69]. Moreover, IFPRI recommended a $2.4 \mathrm{mmt}$ rice stock level to avoid shortfall as seen in 2007-2008 [28]. Under this scenario, we assume that over the next ten years, the GoB will gradually increase its rice stock to $3 \mathrm{mmt}$.

Scenario 3- Import tariff and public stocks: This scenario tests the combined effect of protectionist trade policy and greater rice stocks on Bangladesh rice market and food security.

Scenario 4- Yield gap closure: In this scenario, we explore the idea of ensuring food security by closing the gap between realized yield and attainable rice yield. Timsina et al. [70] stated that Bangladesh's current rice yield is not enough to meet future demand. They estimated that the average yield potential of three major rice crops of Bangladesh could be 3.51 tons/acre. Alam et al. [71] stated that the adoption of best management 
practices, along with appropriate nitrogen management options, could reduce the yield gap by $45 \%$. Since we find no stated government policy goals for future rice production levels or estimates of yield increase as a result of current production enhancement programs, we use the estimate from Alam et al. [71]. We increase the yield by $4.5 \%$ in all years of the projections to reflect an incremental step towards the hypothetically possible $45 \%$ increase over the long run.

We represent the above policy scenarios as though they are costless. Our primary objective is to quantify the shifts in the Bangladesh food security dimensions using these policy tools, not to evaluate these policies' costs or to provide a complete benefit-to-cost assessment.

\section{Results}

\subsection{COVID-19 and Bangladesh's rice market}

The results of the effect of COVID-19 on Bangladesh's rice market are reported in

Table 5. To conserve space, we only report ex-post and ex-ante short and long-run effects.

Table 5. COVID-19 impact (\% change relative to without-COVID-19 baseline)

\begin{tabular}{lrrrrr}
\hline & $2019 / 20$ & $2020 / 21$ & $2021 / 22$ & $2029 / 30$ & $2030 / 31$ \\
\hline Area & $0 \%$ & $-1 \%$ & $-1 \%$ & $3 \%$ & $3 \%$ \\
Yield & $0 \%$ & $0 \%$ & $0 \%$ & $0 \%$ & $0 \%$ \\
Production & $0 \%$ & $-1 \%$ & $-1 \%$ & $3 \%$ & $4 \%$ \\
Net import & $0 \%$ & $0 \%$ & $0 \%$ & $-67 \%$ & $-52 \%$ \\
Total domestic demand & $0 \%$ & $-1 \%$ & $-1 \%$ & $-2 \%$ & $-2 \%$ \\
Ending stocks & $-17 \%$ & $0 \%$ & $1 \%$ & $-1 \%$ & $-1 \%$ \\
Price/KG & $-5 \%$ & $-1 \%$ & $-6 \%$ & $10 \%$ & $11 \%$ \\
\hline \multicolumn{5}{c}{ Food security indicators } & (absolute change) \\
Per capita consumption ratio & 0.00 & -0.01 & -0.01 & -0.03 & -0.03 \\
Real price ratio & -0.05 & -0.01 & -0.07 & 0.09 & 0.09 \\
Self-sufficiency ratio & 0.00 & 0.00 & 0.00 & 0.05 & 0.05 \\
Stocks-to-consumption ratio & -0.01 & 0.00 & 0.00 & 0.00 & 0.00 \\
\hline Source: Authors' calculation & & & & &
\end{tabular}


We did not assume any shocks in FY 2019/20's rice area and yield, as monsoon season rainfed and dry season irrigated rice varieties are usually planted by early February. Therefore, no production effect is reported. The net import status of the country is also unaffected, mostly due to the prohibitive import tariff imposed at the onset of FY 2019/20, which pushed the world price above the autarkic price. Except for ending stock and price, COVID-19 appeared to have little to no impact (mostly zero or less than 1\%) on the Bangladeshi rice market during FY 2019/20. Results (Table 5) show that domestic rice price in FY 2019/20 would have been 5\% higher had there been no pandemic. Such a depressed rice price could be due to the dampened rice demand or the slow pace of the public rice procurement program due to lockdown, which contributed little to raise producers' price. Total domestic demand in FY 2019/20 increased slightly by $0.4 \%$. This is mainly due to the low-income growth caused by COVID-19 related lockdown and mobility restrictions that imposed additional constraints on income-generating activities. The largest immediate impact is on ending stocks, at least in relative terms, which is $17 \%$ lower than in the case of without-COVID-19 levels. The price response reflects how public stocks tend to be used. FAO [72] reports that GoB's special open market operations sell rice at a subsidized price to vulnerable groups, which lends credence to the relative higher starting stocks assumption that we made in the without-COVID-19 model.

As regards food security in FY 2019/20, COVID-19 had a much smaller impact on rice market food stability than on accessibility. The real price ratio dropped by $5 \%$, indicating consumers improved access to rice. The stocks-to-consumption ratio declined marginally and could be explained by GoB's effort to stabilize the market by expanding 
targeted food grain distribution and relief programs that required the additional release of rice from public reserves.

As noted earlier, caution should be exercised as the changes in post-COVID-19 price projections by World Bank might not just because of the pandemic alone. There seems resurgence in world demand and/or a reduction in world supply that causes long-run world prices to be higher in post-COVID-19 projections. These world market patterns projected by the World Bank could be related to other factors.

The ex-ante short-run (FY 2020/21-FY 2021/22) effect of COVID-19 on rice production is negative, but in the long run (FY 2029/30-FY 2030/31), production increases by an average of $3 \%$. The supply response occurring mostly through acreage change can be explained by the changes in domestic price. In the short run, price is determined endogenously in the domestic market, and no net import changes are reported. In the long run, domestic price trades at import parity level triggering demand for import. However, with-COVID-19, net imports are, on average, $60 \%$ smaller than that of the withoutCOVID-19 model. This is due to the relatively improved self-sufficiency caused by the fall in domestic demand compared to without-COVID-19 levels during the projection periods. The dampening effect of eroding purchasing power due to income loss coupled with price hikes in later baseline years explains such a fall in domestic demand. On the other hand, the pandemic's effect on ending stock is relatively negligible and attributable to the domestic price change. With regard to food security indicators in the future, COVID-19 negatively affects rice availability, as per capita consumption of rice is projected to fall by an average of $2 \%$ during the projection period. The effect on rice accessibility is mixed, as the real price ratio improves in the short-run but reverses in the end by an average of $9 \%$. 
The long-run self-sufficiency ratio increases by an average of $5 \%$, indicating an improvement in rice market stability, whereas the stocks-to-consumption ratio remains unchanged.

\subsection{Baseline projections}

A 10-year rice supply and demand outlook is developed for FY 2020/21 to 2030/31 with-COVID-19 macroeconomic and world price assumptions. We also assume normal weather and continuation of macro and trade policies in place in Autumn 2020.

The results (Table 6) indicate that rice production in Bangladesh is projected to reach 48 mmt in FY 2030/31, reflecting a gradual increase in acreage and yield during the projection period. A steady rise in nominal rice price from BDT (Bangladeshi Taka) 34/Kilogram (KG) in $2021 / 22$ to BDT $57 / \mathrm{KG}$ in FY 2030/31 induces farmers to increase their land allocation, on average, by $0.6 \%$ annually. Influenced by higher domestic price and positive long-run trends, rice yield is also projected to increase from 1.4 ton/acre in FY 2021/22 to 1.6 ton/acre in FY 2030/31. Despite production improvements, a gradual increase in domestic demand fueled by positive income growth outpaces the increase in production. Although a continuation of the $55 \%$ import tariff appears to be sufficiently large to drive net import to zero until FY 2027/28, the evolving market conditions eventually cause the price to rise to the import parity level allowing trade to pass over the current tariff in the later baseline years. Net import and domestic demand reach $2.4 \mathrm{mmt}$ and $50 \mathrm{mmt}$ by FY 2030/31, respectively. Ending stock, on the other hand, remains steady around one mmt during the projection period. 


\section{Table 6. Baseline projections}

\begin{tabular}{|c|c|c|c|c|c|c|c|c|c|c|}
\hline & $2021 / 22$ & $2022 / 23$ & $2023 / 24$ & $2024 / 25$ & $2025 / 26$ & $2026 / 27$ & $2027 / 28$ & $2028 / 29$ & $2029 / 30$ & $2030 / 31$ \\
\hline Area & 28,427 & 28,516 & 28,572 & 28,929 & 29,234 & 29,432 & 29,647 & 29,912 & 30,110 & 30,099 \\
\hline Yield & 1.36 & 1.39 & 1.41 & 1.44 & 1.46 & 1.49 & 1.52 & 1.54 & 1.56 & 1.59 \\
\hline Production & 38,633 & 39,527 & 40,383 & 41,621 & 42,797 & 43,852 & 44,945 & 46,083 & 47,073 & 47,766 \\
\hline Net import & 0 & 0 & 0 & 0 & 0 & 0 & 0 & 335 & 1292 & 2393 \\
\hline $\begin{array}{l}\text { Total domestic } \\
\text { demand }\end{array}$ & 38,624 & 39,532 & 40,388 & 41,621 & 42,798 & 43,854 & 44,946 & 46,416 & 48,360 & 50,155 \\
\hline Ending stocks & 1051 & 1046 & 1041 & 1041 & 1041 & 1039 & 1038 & 1039 & 1044 & 1047 \\
\hline Price/KG & 34 & 37 & 40 & 43 & 45 & 48 & 52 & 54 & 55 & 57 \\
\hline \multicolumn{11}{|c|}{ Food security indicators (absolute change) } \\
\hline $\begin{array}{l}\text { Per capita } \\
\text { consumption } \\
\text { ratio }\end{array}$ & 0.98 & 0.99 & 1.00 & 1.02 & 1.04 & 1.06 & 1.08 & 1.11 & 1.15 & 1.19 \\
\hline Real price ratio & 0.97 & 1.00 & 1.03 & 1.03 & 1.03 & 1.04 & 1.06 & 1.05 & 1.02 & 0.99 \\
\hline $\begin{array}{l}\text { Self-sufficiency } \\
\text { ratio }\end{array}$ & 1.00 & 1.00 & 1.00 & 1.00 & 1.00 & 1.00 & 1.00 & 0.99 & 0.97 & 0.95 \\
\hline $\begin{array}{l}\text { Stocks-to- } \\
\text { consumption } \\
\text { ratio }\end{array}$ & 0.03 & 0.03 & 0.03 & 0.03 & 0.03 & 0.03 & 0.03 & 0.03 & 0.02 & 0.02 \\
\hline
\end{tabular}

With regards to food security, rice availability appears to improve as the per capita consumption ratio increases from 0.98 in FY 2021/22 to 1.19 in FY 2030/31. Results for rice accessibility, proxied by the real price ratio, are mixed. The real price ratio increases during autarky years and reverses with the start of imports, implying net rice consumers' terms of access to rice will be positively affected by the change of trade regime. The effect of regime change is opposite for the stability dimension as the self-sufficiency ratio is projected to fall during the later baseline years. The stocks-to-consumption ratio, another proxy for Bangladesh's rice market stability, does not change significantly, only marginally decreasing from 0.03 in $2021 / 22$ to 0.02 in $2030 / 31$. It should be noted that such a trend in ending stock is determined exclusively by the modeling approach, where we assumed domestic price is the key driver of the GoB's stock behavior. We considered alternative approaches, but the historical estimates of the impact of price on public stocks appeared to 
support this representation. We subject this assumption, as well as other policy assumptions, to additional analysis in the next section.

\subsection{Scenario analysis}

\subsubsection{Scenario 1- Import tariff}

Under this scenario, we increase the current $55 \%$ import tariff to $90 \%$. The estimated effects of a high import tariff on the Bangladeshi rice market are reported in Table 7.

Table 7. Changes from baseline projections- higher import tariff

\begin{tabular}{lrrrr}
\hline & $2021 / 22$ & $2022 / 23$ & $2029 / 30$ & $2030 / 31$ \\
\hline Area & $0 \%$ & $0 \%$ & $0 \%$ & $1 \%$ \\
Yield & $0 \%$ & $0 \%$ & $0 \%$ & $0 \%$ \\
Production & $0 \%$ & $0 \%$ & $1 \%$ & $2 \%$ \\
Net import & $0 \%$ & $0 \%$ & $-100 \%$ & $-100 \%$ \\
Total domestic demand & $0 \%$ & $0 \%$ & $-2 \%$ & $-3 \%$ \\
Ending stocks & $0 \%$ & $0 \%$ & $-1 \%$ & $-1 \%$ \\
Price/KG & $0 \%$ & $0 \%$ & $6 \%$ & $10 \%$ \\
\hline \multicolumn{2}{c}{ Food security indicators (absolute change) } \\
Per capita consumption ratio & 0.00 & 0.00 & -0.03 & -0.04 \\
Real price ratio & 0.00 & 0.00 & 0.06 & 0.10 \\
Self-sufficiency ratio & 0.00 & 0.00 & 0.03 & 0.05 \\
Stocks-to-consumption ratio & 0.00 & 0.00 & 0.00 & 0.00 \\
\hline Source: Authors' calculation & & & &
\end{tabular}

No effects are reported in the early baseline years due to the absence of imports at that time since the tariff is already prohibitive. However, in the later years, a $90 \%$ import tariff eliminates net import, resulting in higher domestic production, lower domestic consumption, and lower ending stocks. Although tariff escalation improves the stability dimension, if judged based on the food security indicators presented here, the effects are negative for rice availability and accessibility. The findings are consistent with that of Minten et al. [45]. Compared to baseline values, the per capita consumption ratio is reduced 
by an average of $4 \%$, and the real price ratio increases by an average of $8 \%$, indicating the waning food security status of Bangladesh by these measures due to the higher import tariff.

\subsubsection{Scenario 2: Public stocks}

In this scenario, we gradually increase the ending stock level to achieve the rice stock holding target of $3 \mathrm{mmt}$ by FY 2030/31. Simulation results are reported in Table 8 . It is important to note that some of the reported changes are big such as $170 \%$ increase in ending stock in FY 2029/30; this is due to the small baseline values and large relative changes.

Table 8. Changes from baseline projections- public stocks

\begin{tabular}{|c|c|c|c|c|}
\hline & $2021 / 22$ & $2022 / 23$ & $2029 / 30$ & $2030 / 31$ \\
\hline$\overline{\text { Area }}$ & $0 \%$ & $0 \%$ & $0 \%$ & $0 \%$ \\
\hline Yield & $0 \%$ & $0 \%$ & $0 \%$ & $0 \%$ \\
\hline Production & $0 \%$ & $0 \%$ & $0 \%$ & $0 \%$ \\
\hline Net import & $0 \%$ & $0 \%$ & $10 \%$ & $7 \%$ \\
\hline Total domestic demand & $0 \%$ & $0 \%$ & $0 \%$ & $0 \%$ \\
\hline Ending stocks & $33 \%$ & $51 \%$ & $170 \%$ & $186 \%$ \\
\hline Price/KG & $1 \%$ & $1 \%$ & $0 \%$ & $0 \%$ \\
\hline \multicolumn{5}{|c|}{ Food security indicators (absolute change) } \\
\hline Per capita consumption ratio & 0.00 & 0.00 & 0.00 & 0.00 \\
\hline Real price ratio & 0.01 & 0.01 & 0.00 & 0.00 \\
\hline Self-sufficiency ratio & 0.00 & 0.00 & 0.00 & 0.00 \\
\hline Stocks-to-consumption ratio & 0.01 & 0.01 & 0.04 & 0.04 \\
\hline
\end{tabular}

The results show that shocks in public stocks increase the price by an average of 1\%. In the long run, the domestic price is driven by the world price and arbitrage, independent of domestic supply and demand. Therefore, except for net import, no other changes are reported. However, looking at the food security indicators, we observe some improvements in the stability dimension, mainly due to the improvement in the stock level. 


\subsubsection{Scenario 3: Import tariff and public stocks}

This scenario simulates the impact of the simultaneous implementation of a protectionist policy and stock build-up on the Bangladeshi rice market and food security. Results (Table 9) indicate that in the long run, Bangladesh's rice market switches from import parity to autarky in response to the dual shocks in tariff and stocks. Such shocks effectively eliminate trade and put downward pressure on domestic demand by raising the price.

Table 9. Changes from baseline projections- higher import tariff and public stocks

\begin{tabular}{lrrrr}
\hline & $2021 / 22$ & $2022 / 23$ & $2029 / 30$ & $2030 / 31$ \\
\hline Area & $0 \%$ & $0 \%$ & $0 \%$ & $1 \%$ \\
Yield & $0 \%$ & $0 \%$ & $0 \%$ & $0 \%$ \\
Production & $0 \%$ & $0 \%$ & $1 \%$ & $2 \%$ \\
Net import & $0 \%$ & $0 \%$ & $-100 \%$ & $-100 \%$ \\
Total domestic demand & $0 \%$ & $0 \%$ & $-2 \%$ & $-3 \%$ \\
Ending stocks & $17 \%$ & $33 \%$ & $170 \%$ & $186 \%$ \\
Price/KG & $1 \%$ & $1 \%$ & $7 \%$ & $11 \%$ \\
\hline \multicolumn{2}{c}{ Food security indicators (absolute change) } \\
\hline Per capita consumption ratio & 0.00 & 0.00 & -0.03 & -0.05 \\
Real price ratio & 0.01 & 0.01 & 0.07 & 0.11 \\
Self-sufficiency ratio & 0.00 & 0.00 & 0.03 & 0.05 \\
Stocks-to-consumption ratio & 0.01 & 0.02 & 0.04 & 0.05 \\
\hline
\end{tabular}

Source: Authors' calculation

With regard to food security indicators, rice availability and accessibility deteriorate as a consequence of protectionist measures and larger rice stockpiles. The per capita consumption ratio declines by an average of $4 \%$; this is mainly due to the adjustment in rice consumption in order to buffer price shocks. The real price ratio increases by an average of $9 \%$, leading to a fall in longer-run access to rice. The stability of Bangladesh food security is enhanced as both the self-sufficiency and stocks-to-consumption ratio improve relative to the baseline levels. The self-sufficiency ratio increases in the long run, 
indicating greater domestic supply and reduced dependency on trade for meeting demand. Gradual improvement in the stocks-to-consumption ratio indicates an enhancement in the GoB's capacity to cope with market demand and supply shocks.

\subsubsection{Scenario 4: Yield gap closure}

In this scenario, we implicitly assume that ongoing government initiatives (e.g., input subsidy, soil management, land improvement, extension services) to boost productivity affect rice yield positively. This hypothetical case assumes that such policies successfully increase rice yield and yet ignores the costs of these policies. Nevertheless, because improved productivity is a stated goal, the implications for the rice market and food security are relevant.

Results (Table 10) indicate that domestic price decreases by an average of 6\% in the first few years but remains unaffected in the later baseline years. This indicates that the effect of yield shocks on price is more pronounced when the market operates under autarky and has no price effect when arbitrage through trade links domestic and world price. The resultant decline in price triggers market adjustments, such as less acreage planted. Production, consumption, and ending stocks are greater in these early years. Domestic price in later baseline years is predetermined by the world price, so no response in price is possible since downward pressure caused by greater production affects the amount traded rather than global rice prices. In the absence of price shocks, changes in domestic supply or demand relative to the baseline are not expected. Nonetheless, the long-run negative acreage response found here is not contrary to the theoretical expectations. There are delays between price changes and eventual crop production due to evolving expectations and lags inherent in crop production. As such, the lower crop returns in the early years cause 
sustained area reduction relative to the baseline. However, the area effects are dissipating by the end of the projection period and would likely reverse in time if producers were motivated by the combination of higher yield and unchanged price to plant more rice area than in the baseline.

Table 10. Changes from baseline projections- yield gap closure

\begin{tabular}{lrrrr}
\hline & $2021 / 22$ & $2022 / 23$ & $2029 / 30$ & $2030 / 31$ \\
\hline Area & $-1 \%$ & $-2 \%$ & $-2 \%$ & $-1 \%$ \\
Yield & $4 \%$ & $4 \%$ & $5 \%$ & $5 \%$ \\
Production & $3 \%$ & $2 \%$ & $3 \%$ & $4 \%$ \\
Net import & $0 \%$ & $0 \%$ & $-94 \%$ & $-67 \%$ \\
Total domestic demand & $3 \%$ & $2 \%$ & $0 \%$ & $0 \%$ \\
Ending stocks & $1 \%$ & $1 \%$ & $0 \%$ & $0 \%$ \\
Price/KG & $-7 \%$ & $-5 \%$ & $0 \%$ & $0 \%$ \\
\hline \multicolumn{2}{c}{ Food security indicators (absolute change) } \\
Per capita consumption ratio & 0.03 & 0.02 & 0.00 & 0.00 \\
Real price ratio & -0.07 & -0.05 & 0.00 & 0.00 \\
Self-sufficiency ratio & 0.00 & 0.00 & 0.03 & 0.03 \\
Stocks-to-consumption ratio & 0.00 & 0.00 & 0.00 & 0.00 \\
\hline Source: Authors' calculation & \multicolumn{3}{c}{}
\end{tabular}

In the short run, the positive yield shock improves rice availability and accessibility. The per capita consumption ratio increases by an average of $3 \%$, and the real price ratio drops by $6 \%$, indicating an expansion in rice consumption and improved market access. Regarding long-run food security, the rise in the self-sufficiency ratio indicates an improvement in the rice market stability.

\subsection{Pandemic, policies, and Bangladesh food security}

This section evaluates the impact of a hypothetical pandemic on Bangladesh food security in the event that the policies mentioned above are put in place. We do this by replicating shocks, similar to COVID-19 in FY 2027/28 and FY 2028/29 in terms of macroeconomic variables and world price effects. In other words, we estimate the impacts 
of another, similar pandemic on the Bangladesh rice market with each of these policies in place as well as without any of them implemented. The hypothetical future pandemic is represented by repeating the percent changes in macroeconomic variables and world rice prices that our data sources estimate in FY 2019/20 and FY 2020/20 in the future period. Table 11 reports changes in food security indicators caused by a hypothetical pandemic starting in FY 2027/28 with and without the above listed policies in place. Detailed results are outlined in Supplement S3. Results indicate that the hypothetical pandemic without policy changes shifts the trade regime from import parity to autarky, puts downward pressure on domestic production, consumption, and price, and increases ending stocks. The last year effects are, however, different because the lower prices lead to less area as compared to the baseline, which after being priced out of world markets, combines to raise the domestic price as compared to baseline levels. Since the Bangladesh rice market becomes autarkic due to the hypothetical pandemic, we only considered policy options (public stockholding and yield gap closure) that can influence price when determined by domestic supply and demand. 
Table 11. Food security, hypothetical future pandemic, and policies- \% change relative to baseline

\begin{tabular}{|c|c|c|c|c|}
\hline \multicolumn{5}{|c|}{ Hypothetical future pandemic- no pre-existing policy } \\
\hline & $2027 / 28$ & $2028 / 29$ & $2029 / 30$ & $2030 / 31$ \\
\hline Per capita consumption ratio & $0 \%$ & $-2 \%$ & $-5 \%$ & $-7 \%$ \\
\hline Real price ratio & $-5 \%$ & $-9 \%$ & $-2 \%$ & $3 \%$ \\
\hline Self-sufficiency ratio & $0 \%$ & $1 \%$ & $3 \%$ & $5 \%$ \\
\hline Stocks-to-consumption ratio & $1 \%$ & $3 \%$ & $6 \%$ & $7 \%$ \\
\hline \multicolumn{5}{|c|}{ Hypothetical future pandemic- pre-existing stock policy } \\
\hline Per capita consumption ratio & $0 \%$ & $-2 \%$ & $-5 \%$ & $-7 \%$ \\
\hline Real price ratio & $-4 \%$ & $-8 \%$ & $-1 \%$ & $4 \%$ \\
\hline Self-sufficiency ratio & $0 \%$ & $1 \%$ & $3 \%$ & $5 \%$ \\
\hline Stocks-to-consumption ratio & $139 \%$ & $160 \%$ & $186 \%$ & $209 \%$ \\
\hline \multicolumn{5}{|c|}{ Hypothetical future pandemic- pre-existing yield gap closure policy } \\
\hline Per capita consumption ratio & $2 \%$ & $0 \%$ & $-3 \%$ & $-5 \%$ \\
\hline Real price ratio & $-10 \%$ & $-14 \%$ & $-7 \%$ & $-2 \%$ \\
\hline Self-sufficiency ratio & $0 \%$ & $1 \%$ & $3 \%$ & $5 \%$ \\
\hline Stocks-to-consumption ratio & $0 \%$ & $2 \%$ & $4 \%$ & $6 \%$ \\
\hline
\end{tabular}

Table 11 (hypothetical future pandemic: no pre-existing policy) indicates that during the period FY 2027/28 to FY 2030/31, the per capita consumption ratio and real price ratio decrease by an average of $4 \%$ and $3 \%$, respectively. The self-sufficiency ratio and stocks-to-consumption ratio, on the other hand, increase by an average of $2 \%$ and $4 \%$. The table (hypothetical future pandemic- pre-existing stock policy scenario) also shows a pre-existing stock policy improves only rice stability, not rice availability or accessibility when compared to estimates obtained under no policy or production enhancement policy scenario. A pre-existing production enhancement policy, on the other hand, better smooths the effect of the pandemic on rice availability and accessibility as the per capita consumption ratio and real price ratio decrease by an average of $1 \%$ and $9 \%$, respectively. Furthermore, with the exception of the stocks-to-consumption ratio under the stock policy 
scenario, such a policy yields estimates of the stability indicators, which is quite similar to that of estimated under other scenarios.

\section{Conclusions}

This paper analyzed the impacts of COVID-19 on the Bangladeshi rice market within the framework of a partial equilibrium regime-switching model, and is the first such exercise of which we are aware. We provided an initial estimate of the short- and long-run effects of COVID-19 on the Bangladeshi rice market and food security sustainability by comparing baseline projections. We analyzed the effect of shocks in policies related to trade, public stock, and productivity on rice supply, demand, and food security dimensions. Finally, we assessed the effectiveness of these policies to smooth out shocks that may arise from a future pandemic similar to COVID-19.

The analysis showed that COVID-19 causes a shift in the rice trade regime, supply, and demand in the coming years. We found that the pandemic has had a mixed impact on the Bangladeshi rice market and food security. The short-run domestic prices are lower than they would be otherwise. Long-term prospects for post-COVID-19 rice supply, demand, and trade indicate a weakened Bangladeshi food security. Income shocks reduce per capita domestic demand during the projection period. The lower short-run prices cause sluggish production growth in later years, which, when combined with slower but continued growth in domestic demand, result in a higher price in later baseline years. COVID-19 improves self-sufficiency in rice by causing a reduction in imports. With regards to aggregate food security, the findings appear mixed. Rice availability improves due to the rise in per capita consumption. The real rice price remains relatively constant, indicating access to rice is not jeopardized during the projection period given the 
assumptions. However, the rice market stability indicators deteriorate largely due to the rise in imports in the later baseline years and slow public stock growth.

With regard to policy experiments, a higher import tariff helps to improve selfsufficiency status but undermines rice availability and accessibility by bending the market toward a restrictive trade regime. The experiment with public stock policy reveals that increasing the ending stock incrementally, even up to the targeted level of $3 \mathrm{mmt}$, has limited implications for rice market fundamentals and food security indicators, particularly as long as stocks can be increased through greater imports. The results also indicate that having such a policy does not necessarily provide a large buffer against future market disruptions stemming from an event with repercussions similar to COVID-19. Conversely, combining public stock and import tariff policy was shown to improve rice market stability, however doing so also curbs the consumer demand by raising the domestic price. The results of the yield gap closure scenario indicate that yield increase positively affects rice availability, accessibility, and stability and hence improves the short- and long-run food security of Bangladesh. The analysis also shows that such a policy better insulates the Bangladesh rice market from the depressing effect of a COVID-19 like pandemic compared to other scenarios considered. However, as noted earlier, policies that successfully increase yields could be costly and have apparently been elusive.

Bangladesh's food security has already been challenged by growing population, reduced acreage supply, and climate change [73,74]. COVID-19, however, posed policy challenges that policymakers have not experienced before, namely responding simultaneously to demand-side shocks triggered by declining income levels and to supplyside shocks caused by disruption in trade. Apart from relying on short-run policies such as 
expanding social safety net programs to deal with transitory food insecurity, policymakers may also focus on long-run food and trade policies to sustain food security and build resilience against future shocks. Policy recommendations aligned with the findings of this study are to recognize the scope for an open trade regime that permits rice imports to offset domestic production shortages and price volatility, to bear in mind the potential for productivity improvement to bridge the supply gap between demand and domestic production, and to balance the benefits from strategic grain reserves in terms of stabilizing prices and consumption with the cost of rice procurement, storage, and administration.

Our modeling approach provides an objective assessment of rice market's fundamentals and the current policy environment. Nonetheless, there are limitations to our study and certain improvements can be made for a more nuanced assessment. For example, future research efforts could focus on capturing the impact of relevant economy-wide distortions on the Bangladeshi rice market, analyzing the impact of different scenarios reflecting altered macroeconomic assumptions and world price, and the dynamics between this market and other agricultural and non-agricultural sectors. Future research that aims to contribute to evidence-based policy decision-making could also consider distortionary and fiscal costs of policy interventions. Moreover, our results depend on the baseline conditions and also on the sources of future shocks (e.g., supply, demand, and pandemic). The regime switching caused by trade policy represents an important contribution of the model developed here, yet also suggests that market and food security effects of a shock can depend on initial conditions, particularly whether there is trade at the going border price (with tariff) or not. As such, long-run world price projections are one critical input, but the 
future after the COVID-19 pandemic is uncertain and the future in the event of another global pandemic is even less clear.

To summarize, while there are limits to our assessment, this research can help concerned stakeholders, especially policymakers, to better understand the dynamics of the Bangladeshi rice market as well as improve the debate over policy choices to achieve goals relating to the food security of Bangladesh. More importantly, the insights generated can help devise policy options that aim to build resilience against shocks akin to COVID-19. Results for this case might be relevant for other developing countries whose staple foods are provided through a combination of domestic production and imports. 


\section{References}

1. Rosegrant, M.W.; Cline, S.A. Global Food Security: Challenges and Policies. Science 2003, 302, 1917-1919, doi:10.1126/science.1092958.

2. Mittal, A. The 2008 Food Price Crisis: Rethinking Food Security Policies; Research papers for the Intergovernmental Group of Twenty-Four on International Monetary Affairs and Development; United Nations, 2009;

3. Food and Agriculture Organization (FAO) Food and Agriculture: Key to Achieving the 2030 Agenda for Sustainable Development; Food and Agriculture Organization (FAO): Rome, Italy, 2016;

4. Barrett, C.B. Measuring Food Insecurity. Science 2010, 327, 825-828, doi:10.1126/science. 1182768 .

5. $\quad$ United Nations The Global Social Crisis: Report on the World Social Situation 2011; Economic and Social Affairs; United Nations Publications: New York, 2011; ISBN 978-92-1-130304-9.

6. Devereux, S.; Béné, C.; Hoddinott, J. Conceptualising COVID-19's Impacts on Household Food Security. Food Secur. 2020, 12, 769-772, doi:10.1007/s12571-02001085-0.

7. Farcas, A.C.; Galanakis, C.M.; Socaciu, C.; Pop, O.L.; Tibulca, D.; Paucean, A.; Jimborean, M.A.; Fogarasi, M.; Salanta, L.C.; Tofana, M.; et al. Food Security during the Pandemic and the Importance of the Bioeconomy in the New Era. Sustainability 2021, 13, 150, doi:10.3390/su13010150.

8. High-Level Panel of Experts on Food Security and Nutrition (HLPE) Impact of COVID-19 on Food Security and Nutrition (FSN); Food and Agriculture Organization (FAO): Rome, Italy, 2020;

9. World Food Programme (WFP) WFP Global Update on COVID-19: November 2020; World Food Programme (WFP): Rome, Italy, 2020;

10. Ivanic, M.; Martin, W. Implications of Higher Global Food Prices for Poverty in LowIncome Countries1. Agric. Econ. 2008, 39, 405-416, doi:https://doi.org/10.1111/j.1574-0862.2008.00347.x.

11. Martin-Prevel, Y.; Becquey, E.; Tapsoba, S.; Castan, F.; Coulibaly, D.; Fortin, S.; Zoungrana, M.; Lange, M.; Delpeuch, F.; Savy, M. The 2008 Food Price Crisis Negatively Affected Household Food Security and Dietary Diversity in Urban Burkina Faso. J. Nutr. 2012, 142, 1748-1755, doi:10.3945/jn.112.159996. 
12. Warr, P.; Yusuf, A.A. World Food Prices and Poverty in Indonesia. Aust. J. Agric. Resour. Econ. 2014, 58, 1-21, doi:https://doi.org/10.1111/1467-8489.12015.

13. Akter, S.; Basher, S.A. The Impacts of Food Price and Income Shocks on Household Food Security and Economic Well-Being: Evidence from Rural Bangladesh. Glob. Environ. Change 2014, 25, 150-162, doi:10.1016/j.gloenvcha.2014.02.003.

14. Badolo, F.; Traoré, F. Impact of Rising World Rice Prices on Poverty and Inequality in Burkina Faso. Dev. Policy Rev. 2015, 33, 221-244, doi:https://doi.org/10.1111/dpr.12099.

15. Food and Agriculture Organization The State of Food Insecurity in the World 2011: How Does International Price Volatility Affect Domestic Economies and Food Security? 2011.

16. Sayeed, K.A.; Yunus, M.M. Rice Prices and Growth, and Poverty Reduction in Bangladesh; Food and Agriculture Organization (FAO): Rome, Italy, 2018; ISBN 978-92-5-130107-4.

17. Ministry of Food (MoF) National Food Policy 2006.

18. Amjath-Babu, T.S.; Krupnik, T.J.; Thilsted, S.H.; McDonald, A.J. Key Indicators for Monitoring Food System Disruptions Caused by the COVID-19 Pandemic: Insights from Bangladesh towards Effective Response. Food Secur. 2020, 12, 761-768, doi:10.1007/s12571-020-01083-2.

19. Espitia, A.; Rocha, N.; Ruta, M. Covid-19 and Food Protectionism: The Impact of the Pandemic and Export Restrictions on World Food Markets; Policy Research Working Paper Series; The World Bank, 2020;

20. Laborde, D.; Martin, W.; Swinnen, J.; Vos, R. Poverty and Food Insecurity Could Grow Dramatically as COVID-19 Spreads. IFPRI Blog Res. Post 2020.

21. Del Ninno, C.; Dorosh, P.A.; Smith, L.C.; Roy, D.K. The 1998 Floods in Bangladesh: Disaster Impacts, Household Coping Strategies, and Responses; Research reports; International Food Policy Research Institute (IFPRI), 2001;

22. Chen, Y.; Lu, C. A Comparative Analysis on Food Security in Bangladesh, India and Myanmar. Sustainability 2018, 10, 405, doi:10.3390/su10020405.

23. Dorosh, P.A.; Shahabuddin, Q.; Rahman, M.S. Price Responsiveness of Foodgrain Supply in Bangladesh and Projections 2020. Bangladesh Dev. Stud. 2002, 28, 47-75.

24. Ganesh-Kumar, A.; Prasad, S.K.; Pullabhotla, H. Supply and Demand for Cereals in Bangladesh: 2010-2030; IFPRI discussion papers; International Food Policy Research Institute (IFPRI), 2012; 
25. Mainuddin, M.; Kirby, M. National Food Security in Bangladesh to 2050. Food Secur. 2015, 7, 633-646, doi:10.1007/s12571-015-0465-6.

26. Hossain, M.; Yunus, M. Estimates of Per Capita Consumption of Food Grains in Bangladesh. Bangladesh Dev. Stud. 2016, 39, 103-116.

27. Goletti, F.; Ahmed, R.; Chowdhury, N. Optimal Stock for the Public Food Grain Distribution System in Bangladesh; International Food Policy Research Institute (IFPRI): Washington, DC, 1991;

28. Dorosh, P.A.; Rashid, S. Bangladesh Rice Trade and Price Stabilization: Implications of the 2007/08 Experience for Public Stocks; IFPRI discussion papers; International Food Policy Research Institute (IFPRI), 2012;

29. Alaimo, L.S.; Fiore, M.; Galati, A. Measuring Consumers' Level of Satisfaction for Online Food Shopping during COVID-19 in Italy Using POSETs. Socioecon. Plann. Sci. 2021, 101064, doi:10.1016/j.seps.2021.101064.

30. Alaimo, L.S.; Fiore, M.; Galati, A. How the Covid-19 Pandemic Is Changing Online Food Shopping Human Behaviour in Italy. Sustainability 2020, 12, 9594, doi:10.3390/su12229594.

31. Christa, U.; Kristinae, V. The Effect of Product Innovation on Business Performance during COVID 19 Pandemic. Uncertain Supply Chain Manag. 2021, 9, 151-158.

32. Purwanto, A.; Asbari, M.; Fahlevi, M.; Mufid, A.; Agistiawati, E.; Cahyono, Y.; Suryani, P. Impact of Work From Home (WFH) on Indonesian Teachers Performance During the Covid-19 Pandemic: An Exploratory Study. Int. J. Adv. Sci. Technol. 2020, 29, 6235-6244.

33. Early Estimates of the Impacts of COVID-19 on U.S. Agricultural Commodity Markets, Farm Income and Government Outlays; Food and Agricultural Policy Research Institute: Columbia, Missouri, 2020;

34. The Impact of COVID-19 on Agricultural Markets and GHG Emissions; OECD Policy Responses to Coronavirus (COVID-19); Organisation for Economic Cooperation and Development, 2020;

35. Fathelrahman, E.; Davies, S.; Muhammad, S. Food Trade Openness and Enhancement of Food Security - Partial Equilibrium Model Simulations for Selected Countries. Sustainability 2021, 13, 4107, doi:10.3390/su13084107.

36. Coady, D.; Dorosh, P.; Minten, B. Evaluating Alternative Policy Responses to Higher World Food Prices: The Case of Increasing Rice Prices in Madagascar. Am. J. Agric. Econ. 2009, 91, 711-722, doi:https://doi.org/10.1111/j.1467-8276.2009.01266.x. 
37. Takahashi, D. The Distributional Effect of the Rice Policy in Japan, 1986-2010. Food Policy 2012, 37, 679-689, doi:10.1016/j.foodpol.2012.07.008.

38. Permani, R.; Vanzetti, D. Rice Mountain: Assessment of the Thai Rice Pledging Program. Agric. Econ. 2016, 47, 273-284, doi:https://doi.org/10.1111/agec.12228.

39. Qtaishat, T.H.; El-Habbab, M.S.; Bumblauskas, D.P. Welfare Economic Analysis of Lifting Water Subsidies for Banana Farms in Jordan. Sustainability 2019, 11, 5118, doi:10.3390/su11185118.

40. Devadoss, S.; Meyers, W.H. Variability in Wheat Export Demand Elasticity: Policy Implications. Agric. Econ. 1990, 4, 381-394, doi:10.1016/0169-5150(90)90012-P.

41. Riethmuller, P.; Roe, T. Government Intervention in Commodity Markets: The Case of Japanese Rice and Wheat Policy. J. Policy Model. 1986, 8, 327-349, doi:10.1016/0161-8938(86)90017-7.

42. Kozicka, M.; Kalkuhl, M.; Brockhaus, J. Food Grain Policies in India and Their Implications for Stocks and Fiscal Costs: A Dynamic Partial Equilibrium Analysis. $J$. Agric. Econ. 2017, 68, 98-122, doi:https://doi.org/10.1111/1477-9552.12176.

43. Food and Agriculture Organization Country Fact Sheet on Food and Agriculture Policy Trends - Bangladesh 2016.

44. Del Ninno, C.; Dorosh, P.A.; Smith, L.C. Public Policy, Markets and Household Coping Strategies in Bangladesh: Avoiding a Food Security Crisis Following the 1998 Floods. World Dev. 2003, 31, 1221-1238, doi:10.1016/S0305-750X(03)000718.

45. Minten, B.; Dorosh, P.; Dabat, M.-H.; Jenn-Treyer, O.; Magnay, J.; Razafintsalama, Z. Rice Markets in Madagascar in Disarray: Policy Options for Increased Efficiency and Price Stabilization; The World Bank: Washington, DC, 2006;

46. Dorosh, P.A. Food Price Stabilisation and Food Security: International Experience. Bull. Indones. Econ. Stud. 2008, 44, 93-114, doi:10.1080/00074910802001603.

47. Timmer, C.P.; Falcon, W.P.; Pearson, S.R. Introduction to food policy analysis. In Food policy analysis; Johns Hopkins University Press: Baltimore, Maryland, 1983; pp. 3-18.

48. Murphy, S. Strategic Grain Reserves in an Era of Volatility; Institute for Agriculture and Trade Policy: Minneapolis, MN, 2009;

49. Food Planning and Monitoring Committee (FPMU) National Food Policy Plan of Action, 20082008. 
50. Goletti, F. Price stabilization and the management of public foodgrain stocks in Bangladesh. In Out of the shadows of famine: evolving food markets and food policy in Bangladesh; Ahmed, R., Haggblade, S., Chowdhury, T., Eds.; John Hopkins University Press: Baltimore, Maryland, 2000; pp. 189-212 ISBN 0-8018-6476-3.

51. Godfray, H.C.J.; Beddington, J.R.; Crute, I.R.; Haddad, L.; Lawrence, D.; Muir, J.F.; Pretty, J.; Robinson, S.; Thomas, S.M.; Toulmin, C. Food Security: The Challenge of Feeding 9 Billion People. Science 2010, 327, 812-818, doi:10.1126/science.1185383.

52. Magnani, R.; Oot, L.; Sethuraman, K.; Kabir, G.; Rahman, S. USAID Office of Food for Peace Food Security Country Framework for Bangladesh (FY 2015-2019); FHI 360/FANTA: Washington, DC, 2015;

53. General Economics Division (GED) Outline Perspective Plan of Bangladesh 20102021: Making Vision 2021 a Reality 2010.

54. Hasan, S.A. The Distributional Effect of a Large Rice Price Increase on Welfare and Poverty in Bangladesh. Aust. J. Agric. Resour. Econ. 2017, 61, 154-171, doi:https://doi.org/10.1111/1467-8489.12141.

55. World Bank Food Price Increases in South Asia: National Responses and Regional Dimensions; World Bank: Washington, DC, 2010;

56. Brennan, D. Price Dynamics in the Bangladesh Rice Market: Implications for Public Intervention. Agric. Econ. 2003, 29, 15-25, doi:https://doi.org/10.1111/j.15740862.2003.tb00144.x.

57. Ahmed, A.U.; Shams, Y. Demand Elasticities in Rural Bangladesh: An Application of the AIDS Model. Bangladesh Dev. Stud. 1994, 22, 1-25.

58. Jahan, I. Bangladesh. In Fertilizer subsidies - which way forward?; Huang, J., Gulati, A., Gregory, I., Eds.; IFDC - An International Center for Soil Fertility and Agricultural Development, 2017; pp. 50-98.

59. Thompson, W.; Smith, G.; Elasri, A. The medium-term impacts of trade liberalisation in OECD countries on the food security of non-member economies. In Reforming agricultural trade for developing countries: Quantifying the impact of multilateral trade reform; McCalla, A.F., Nash, J.D., Eds.; World Bank Publications, 2006 ISBN 978-0-8213-6717-9.

60. Burchi, F.; De Muro, P. From Food Availability to Nutritional Capabilities: Advancing Food Security Analysis. Food Policy 2016, 60, 10-19, doi:10.1016/j.foodpol.2015.03.008.

61. International Monetary Fund World Economic Outlook: Global Manufacturing Downturn, Rising Trade Barriers 2019. 
62. International Monetary Fund World Economic Outlook: The Great Lockdown 2020.

63. United Nations World Population Prospects 2019: Volume I: Comprehensive Tables; United Nations: New York, 2019; ISBN 978-92-1-148327-7.

64. World Bank Commodity Markets Outlook: Implications of COVID-19 for Commodities; World Bank: Washington, DC, 2020;

65. World Bank Commodity Markets Outlook: The Role of Substitution in Commodity Demand; World Bank: Washington, DC, 2019;

66. World Bank Global Economic Prospects: Slow Growth, Policy Challenges; World Bank: Washington, DC, 2020;

67. World Bank Global Economic Prospects; World Bank: Washington, DC, 2020;

68. General Economics Division (GED) Seventh Five Year Plan FY2016-FY2020: Accelerating Growth, Empowering Citizens 2015.

69. Kabir, R.I.; Mohammad Yunus; Hossain, T. Public Food Grain Storage Facilities in Bangladesh: An Assessment of Functionality, Repair Needs, and Alternative Usage; International Food Policy Research Institute (IFPRI): Washington, DC, 2019;

70. Timsina, J.; Wolf, J.; Guilpart, N.; van Bussel, L.G.J.; Grassini, P.; van Wart, J.; Hossain, A.; Rashid, H.; Islam, S.; van Ittersum, M.K. Can Bangladesh Produce Enough Cereals to Meet Future Demand? Agric. Syst. 2018, 163, 36-44, doi:10.1016/j.agsy.2016.11.003.

71. Alam, M.M.; Karim, Md.R.; Ladha, J.K. Integrating Best Management Practices for Rice with Farmers' Crop Management Techniques: A Potential Option for Minimizing Rice Yield Gap. Field Crops Res. 2013, 144, 62-68, doi:10.1016/j.fcr.2013.01.010.

72. Food and Agriculture Organization (FAO) Second Rapid Assessment of Food and Nutrition Security in the Context of COVID-19 in Bangladesh: May-July 2020; Food and Agriculture Organization (FAO), 2020; ISBN 978-92-5-133313-6.

73. Hossain, M.; Naher, F.; Shahabuddin, Q. Food Security and Nutrition in Bangladesh: Progress and Determinants. EJADE Electron. J. Agric. Dev. Econ. 2005, 2, 103-132, doi:10.22004/ag.econ.110131.

74. Mohammad A.B. Siddique; Biswas, J.C.; Salam, M.A. Implications of climate change, population and resource scarcity for food security in Bangladesh. In Food security and development: Country case studies; Nagothu, U.S., Ed.; Routledge: London; pp. 104-126 ISBN 978-1-138-70653-8. 


\section{Supplement S1}

\section{Rice supply}

Total domestic rice supply consists of production and beginning stocks. Production is estimated by multiplying total area planted and yield. The area planted and yield equations are symbolized as $a p_{t}$ and $y_{t}$ as shown in Equation (1) and (3).

$a p_{t}=\beta_{0}+\beta_{1} \frac{\left(\operatorname{expr}_{t}+s u b s_{t} * y_{t}\right)}{p i_{t-1}}+\beta_{2} a p_{t-1}$,

where $\operatorname{expr}_{t}$ is the expected return in period $t$, calculated by multiplying expected price and expected yield in $t$. Expected price is the average rice price in the period $(t-1)$ and $(t-2)$. Expected yield (ey) is the trend yield as shown in Equation (2):

ey $=\beta_{0}+\beta_{1}$ trend (2)

Fertilizer subsidy $\left(s u b s_{t}\right)$ by GoB is multiplied by yield to express it in terms of per unit of output. In this and later equations, $p i$ indicates the consumer price index of Bangladesh. Lagged area planted $\left(a p_{t-1}\right)$ indicates a partial adjustment approach.

Rice yield (Equation 3) is estimated as a function of the trend, the real price of milled rice per ton in Bangladesh and subsidy in $t$ :

$y_{t}=\beta_{0}+\beta_{1}$ trend $+\frac{\beta_{2}\left(p_{t}+s u b s_{t}\right)}{p i}$

Beginning stock (Equation 4) in the period $t$ has been modeled as equal to the ending stock in the period $(t-1)$ :

$b s_{t}=e s_{t-1}$

\section{Rice demand}

Domestic demand, seed, feed, and wastage, ending stock and export supply determine the total rice demand of Bangladesh. In this study, we divided net domestic 
demand (domestic demand minus seed, feed, and wastage) by the total population to obtain the per capita net domestic demand for rice.

Per capita net domestic is estimated as follows:

per capita net domestic demand dem $_{0}-\beta_{1} \frac{\text { price }_{t}}{p i_{t}}+\beta_{2} \frac{\text { per capita bd gd } p_{t}}{p i_{t}}$

Ending stock is a behavioral equation estimated as:

$e s_{t}=\beta_{0}+\beta_{1} \frac{1}{\left(\frac{p r i c e_{t}}{p i_{t}}\right)}$

As discussed earlier, GoB has a minimum public stock holding policy. Thus, the curvilinear specification is necessary to partly describe this policy. Also, it generates a reasonably shaped stock demand curve in that the curve gets steeper as price increases and flatter if the price is low.

\section{Model closure}

In this section, we discuss the trade and price component of the model that are used to reach equilibrium.

\subsection{Trade}

Import demand has been estimated from an identity consisting of net import (import minus export in period $t$ ) and

The export supply $\left(\exp _{t}\right)$ in period $t$ (Equation 7) is a behavioral equation specified as:

$\exp _{t}=\beta_{0}-\beta_{1}\left(\frac{\frac{\text { price }_{t}}{\text { ex.rate }_{t}}}{\text { uspit }_{t}}\right)+\beta_{2}\left(\frac{\text { thai. }_{t}}{\text { uspi }_{t}}\right)$

here, ex.rate is $_{t}$ the average exchange rate of United States dollar to Bangladeshi Taka in year $t$, deflated by United State General Price index $\left(u s p i_{t}\right)$. The other external price, thai. $p_{t}$, is the export parity price of $5 \%$ parboiled Thailand rice price. 


\subsection{Price and model closure}

The model has two closure options namely import parity and autarky. Domestic price is estimated independently based on the given market conditions.

The import parity closure is based on the notion that there is a flow of trade between Bangladesh and the rest of the world rice markets. The use of the price linkage equation (Equation 8) formalizes this interaction and defines the degree of price transmission [40]. price $_{t}=\beta_{0}+\beta_{1}\left(\right.$ thai. $p_{t} *$ tariff $_{t} *$ ex.rate $)$

Thus, the domestic price is a function of the Thai rice export price (thai.p), the tariff Bangladesh imposes on rice imports (tariff), and the exchange rate (ex.rate).

The estimated model closes on net trade (Equation 9) and the equilibrium condition is met when total market supply equals total market demand at the prevailing price. Thus, net trade $=$ total domestic demand + ending stock - production

$$
\text { - beginning stock }
$$

Under the autarky trade regime, price is used to close the model without imports. We use a price equilibrator framework to simulate equilibrium price by setting domestic demand equal to domestic supply, defined as follows:

total domestic demand + ending stock $=$ production + beginning stock 


\section{Supplement S2}

\section{Supplement S2 Table 1. Augmented Dickey-Fuller test for unit root}

\begin{tabular}{lll}
\hline & Bangladesh price & Thai 5\% parboiled price \\
\hline Exogeneous & Constant & Constant \\
\hline Lag length (max lag 10) & 4 & 8 \\
\hline P Value- Level & 0.00 & 0.00 \\
t- Statistics & -7.84 & -6.44 \\
$1 \%$ level & -3.46 & -3.46 \\
$5 \%$ level & -2.87 & -2.87 \\
$10 \%$ level & -2.57 & -2.57 \\
\hline Source: Authors' calculation & &
\end{tabular}

\section{Supplement S2 Table 2. Lag length selection}

Endogenous: Bangladesh price, Thai 5\% parboiled price Exogeneous: Constant

\begin{tabular}{rlllll}
\hline Lag & LL & LR & AIC & HQIC & SBIC \\
\hline 0 & -1322.43 & & 22.64 & 22.66 & 22.69 \\
1 & -1292.05 & 60.77 & 22.19 & 22.25 & 22.33 \\
2 & -1270.89 & 42.32 & 21.90 & 21.99 & 22.13 \\
3 & -1218.16 & 105.45 & 21.06 & 21.20 & 21.39 \\
4 & -1217.11 & 2.10 & 21.11 & 21.29 & 21.54 \\
5 & -1197.46 & 39.32 & 20.85 & 21.06 & 21.36 \\
6 & -1151.17 & 92.58 & 20.12 & 20.37 & 20.74 \\
7 & -1118.53 & 65.27 & 19.63 & 19.92 & 20.34 \\
8 & -1109.41 & 18.23 & 19.55 & 19.87 & 20.35 \\
9 & -1079.80 & $59.21^{*}$ & 19.11 & $19.47^{*}$ & $20.00^{*}$ \\
10 & -1075.62 & 8.38 & $19.10^{*}$ & 19.51 & 20.10 \\
\hline
\end{tabular}

Source: Authors' calculation

*Indicates lag order selected by the criteria at $1 \%$ level

Supplement S2 Table 3. Co-integration test: Bangladesh price \& Thai 5\% parboiled price

Trend: constant

Sample: $2000 \mathrm{~m} 1-2020 \mathrm{~m} 10$

Ho: Rank=p

$$
\mathrm{P}=0^{*}
$$

$\mathrm{P}=1 *$

Source: A

Note: *Denotes rejection of the hypothesis at the $1 \%$ level; Trace test indicates 2 cointegrating equations at the $1 \%$ level; Maxeigenvalue test indicates 2 cointegrating equations at the $1 \%$ level
Trace test

Trace statistic

Number of observations: 239 Lags: 9 Maximum eigenvalue test Max $1 \%$ critical value test statistic critical critical value test statistic critical $112.16^{*}$ 19.94

88.63
18.52 $23.53^{*}$ 6.63 23.53 6.63 


\section{Supplement S3}

Supplement S3 Table 1. Hypothetical future pandemic - no policy changes (\% change relative to baseline)

\begin{tabular}{lrrrr}
\hline & $2027 / 28$ & $2028 / 29$ & $2029 / 30$ & $2030 / 31$ \\
\hline Area & $0 \%$ & $-1 \%$ & $-2 \%$ & $-2 \%$ \\
Yield & $0 \%$ & $0 \%$ & $0 \%$ & $0 \%$ \\
Production & $0 \%$ & $-1 \%$ & $-2 \%$ & $-2 \%$ \\
Net import & $0 \%$ & $-100 \%$ & $-100 \%$ & $-100 \%$ \\
Total domestic demand & $0 \%$ & $-2 \%$ & $-5 \%$ & $-6 \%$ \\
Ending stocks & $1 \%$ & $1 \%$ & $0.2 \%$ & $-0.5 \%$ \\
Price/KG & $-5 \%$ & $-9 \%$ & $-2 \%$ & $3 \%$ \\
\hline \multicolumn{5}{r}{ Food security indicators (absolute change) } \\
\hline Per capita consumption ratio & 0.00 & -0.02 & -0.06 & -0.08 \\
Real price ratio & -0.05 & -0.09 & -0.02 & 0.03 \\
Self-sufficiency ratio & 0.00 & 0.01 & 0.03 & 0.05 \\
Stocks-to-consumption ratio & 0.00 & 0.00 & 0.00 & 0.00 \\
\hline Source: Authors' calculation & \multicolumn{5}{c}{}
\end{tabular}

Supplement S3 Table 2. Hypothetical future pandemic- with pre-existing public stock policy (\% change relative to baseline)

\begin{tabular}{lrrrr}
\hline & $2027 / 28$ & $2028 / 29$ & $2029 / 30$ & $2030 / 31$ \\
\hline Area & $0 \%$ & $-1 \%$ & $-2 \%$ & $-2 \%$ \\
Yield & $0 \%$ & $0 \%$ & $0 \%$ & $0 \%$ \\
Production & $0 \%$ & $-1 \%$ & $-2 \%$ & $-2 \%$ \\
Net import & $0 \%$ & $-100 \%$ & $-100 \%$ & $-100 \%$ \\
Total domestic demand & $0 \%$ & $-2 \%$ & $-5 \%$ & $-7 \%$ \\
Ending stocks & $138 \%$ & $155 \%$ & $170 \%$ & $186 \%$ \\
Price/KG & $-4 \%$ & $-8 \%$ & $-1 \%$ & $4 \%$ \\
\hline \multicolumn{4}{c}{ Food security indicators (absolute change) } \\
\hline Per capita consumption ratio & -0.01 & -0.02 & -0.06 & -0.09 \\
Real price ratio & -0.04 & -0.09 & -0.01 & 0.04 \\
Self-sufficiency ratio & 0.00 & 0.01 & 0.03 & 0.05 \\
Stocks-to-consumption ratio & 0.04 & 0.04 & 0.05 & 0.05 \\
\hline Source: Authors' calculation & \multicolumn{5}{c}{}
\end{tabular}


Supplement S3 Table 3. Impacts of a hypothetical future pandemic- with preexisting yield gap closure policy (\% change relative to baseline)

\begin{tabular}{lrrrr}
\hline & $2027 / 28$ & $2028 / 29$ & $2029 / 30$ & $2030 / 31$ \\
\hline Area & $-2 \%$ & $-3 \%$ & $-4 \%$ & $-4 \%$ \\
Yield & $4 \%$ & $4 \%$ & $4 \%$ & $5 \%$ \\
Production & $2 \%$ & $1 \%$ & $0 \%$ & $0 \%$ \\
Net import & $0 \%$ & $-100 \%$ & $-100 \%$ & $-100 \%$ \\
Total domestic demand & $2 \%$ & $0 \%$ & $-3 \%$ & $-4 \%$ \\
Ending stocks & $2 \%$ & $2 \%$ & $1 \%$ & $0 \%$ \\
Price/KG & $-10 \%$ & $-14 \%$ & $-7 \%$ & $-2 \%$ \\
\hline \multicolumn{7}{r}{ Feod security indicators (absolute change) } & & \\
\hline Per capita consumption ratio & 0.02 & 0.00 & -0.03 & -0.06 \\
Real price ratio & -0.11 & -0.15 & -0.07 & -0.02 \\
Self-sufficiency ratio & 0.00 & 0.01 & 0.03 & 0.05 \\
Stocks-to-consumption ratio & 0.00 & 0.00 & 0.00 & 0.00 \\
\hline Source: Authors' calculation & \multicolumn{5}{c}{}
\end{tabular}




\title{
Essay 2: Women's empowerment in agriculture and productivity change: The case of Bangladesh rice farms
}

\begin{abstract}
:
Using productivity change as a measure of farm economic performance, we analyze the relationship between women's empowerment in agriculture and farm productivity change and its components, which include efficiency change, technological change, and scale efficiency change. A non-parametric Malmquist approach is used to measure farm specific productivity change and its decomposition. We use a bootstrap regression to analyze factors that cause differences in productivity change and its components, testing, in particular, the role women's empowerment plays. The empirical application focuses on a sample of Bangladesh rice farms over the crop cultivation period 2011 and 2014. Results suggest that improvements in women's empowerment in agriculture were associated with higher levels of productivity change, efficiency change, and technical change, while they had no impact on scale efficiency change. We find that empowering women, specifically, improving their ability to make independent choices regarding agricultural production had a statistically significant positive association with productivity change, efficiency change, and technical change. We also find that lowering the gender parity gap is positively related with improving productivity of the sample farms.
\end{abstract}

Keywords: women's empowerment; productivity change, Malmquist index, rice farms, Bangladesh. 


\section{Introduction}

Agricultural productivity growth is an important component of any development strategy $[1,2]$. At the farm level, productivity growth can be viewed as an indicator of a farm's ability to persist in an environment where market, regulatory, and environmental pressures may reduce its competitiveness and even lead to farm exit. Given the importance of agricultural productivity growth for development and agriculture's economic sustainability, extensive research has been put into measuring productivity change and understanding the factors that drive it. Prominent among the factors that have been investigated to better understand changes in productivity are farm and farmer characteristics, farm policies, and climatic conditions [3-5]. Women's empowerment and its relationship with farm-level productivity, have not been studied in depth so far, although they might be relevant, especially in developing countries where women make up for $43 \%$ of the agricultural labor force [6].

To date, a number of studies have looked at the effect of women's empowerment in agriculture on farm performance measures, but not specifically on farm productivity change. For example, studies by Bozoğlu and Ceyhan ${ }^{\mathrm{i}}$ [7] and Seymour [8] examined the effect of women's empowerment on farm technical efficiency ${ }^{\mathrm{ii}}$. Bozoğlu \& Ceyhan [7] found that greater participation of women in decision-making and labor activities led to higher levels of farm technical efficiency. On the other hand, Seymour [8] found only a weak positive relationship between women's empowerment (as measured using Women's empowerment in Agriculture Index (WEAI) developed by Alkire et al. [10]) and technical efficiency. Besides technical efficiency studies, another stream of relevant literature has looked at the effect of women's empowerment on crop output quantity. More specifically, 
Diiro et al. [11] employed an abbreviated version of WEAI to study the effect of women's overall empowerment and its individual indicators on maize yield of farm households in western Kenya and found a positive effect on yield. Another study [12] in this area used WEAI to examine the link between women's empowerment and crop output quantity of rural households in Niger and found a positive relationship between these variables.

Against this background, the objective of this study is to assess the effect of women's empowerment in agriculture on farm productivity change. To pursue this objective, and in line with other studies $[8,11,12]$ in the literature, we use the WEAI and related measures of women's empowerment, and test their effect on productivity change of Bangladesh rice farms over the crop cultivation period 2011 and 2014. We focus on rice because rice is the largest crop of Bangladesh and crucial for the country's agricultural development. Rice production accounts for $69 \%$ of the total cultivated area in Bangladesh [13], contributes about $70 \%$ of the agricultural GDP, and provides $75 \%$ of the caloric needs of the nation [14]. We use the Malmquist productivity index to measure productivity change. We further decompose this index into three components: efficiency change, technical change, and scale efficiency change. Then, we use non-parametric bootstrap regression to examine the effect of women's empowerment, its individual domains, and other control variables on farm productivity change and its decomposition.

We contribute to the existing literature in two ways. First, we assess the role of different measures of women's empowerment in agriculture on farm productivity change and its components- a dynamic performance indicator by nature. We are aware of no other study of this type, particularly because so many past studies focus on static assessment presumably due to data limitations. Second, we consider the subjective value judgment of 
the women's empowerment concept and employ alternative specifications of women's empowerment to reaffirm the association between women's empowerment and productivity change and its components. Our research is crucial because it enhances our knowledge about the consequences of promoting women's empowerment on the farm economic sustainability.

\section{Literature Review}

In this section, the relevant literature on productivity change in Bangladesh agriculture is reviewed. The theoretical background of the concept of women's empowerment is presented and discussed. Finally, the empirical literature that links women's empowerment in agriculture with agricultural production, nutrition, and food security is examined. In doing so, we focus attention on the most relevant studies rather than the broad literature on women's empowerment or the long and vast literature on agricultural productivity, including crop yields.

\subsection{Productivity of Bangladesh agriculture}

Growth in agricultural productivity is a fundamental precondition for sustainable economic development, and low agricultural productivity can substantially delay industrialization $[15,16]$. Agricultural growth is effective in reducing poverty, and it mostly affects the poorest of the poor $[17,18]$. A few studies have measured productivity change in Bangladesh agriculture, all at the regional level (greater district). Rahman and Salim [19] and Hossain et al. [20] used non-parametric techniques to measure regional productivity change in Bangladesh agriculture and reported a productivity growth of $0.57 \%$ and $2.95 \%$, respectively. Coelli et al. [21], on the other hand, employed a parametric approach (stochastic frontier analysis) to measure regional productivity growth in 
Bangladesh farming and reported a $0.23 \%$ decline in productivity. These studies also identified farm size, crop specialization, investment in agricultural research and development, extension contact, and extension expenditure as significant determinants of regional productivity change in Bangladesh. Although there are studies [8,22-25] that used farm-level survey data to analyze farm household technical efficiency until now no studies have measured the changes in farm-level productivity and its components of Bangladesh agriculture.

\subsection{Women's empowerment and broader development issues}

Because of the subjective nature of the women's empowerment concept, many definitions have been proposed in the literature. Mehra [26] defined women's empowerment as the expansion of choices and an increase in women's ability to exercise these choices. Kabeer [27] defined empowerment as the expansion in people's ability to make strategic life choices where this ability was previously denied to them. Kabeer's definition offers an extension to the previous definition in that it indicates a priori requirement for empowerment. The definition indicates that to be empowered, it is necessary to be disempowered first, more specifically, to be in a state where a woman had limited or no freedom of choices, expressions, and actions. Mosedale [28] discussed four characteristics of empowerment: first, the issue of empowerment arises because of the prevalence of disempowerment; second, the urge for empowerment comes from within, it cannot be bestowed by a third party such as government agencies or NGOs; third, being empowered means ability to make and implement decisions regarding aspects that matter most to individuals; and fourth, empowerment is an ongoing process in which people are empowered or disempowered relative to others or themselves in the past. Batliwala [29] 
further extended the idea and conceptualized empowerment as a socio-political process, where political, social, and economic power shifts between and across both individuals and social groups. All these discussions lead us to two unique defining features of women's empowerment concept: the process, transformation towards greater freedom of choice, action, and equality; and the agency, woman as an agent of change influences important life outcomes by formulating strategic choices and controlling resources and decisions [30]. For the purpose of this study, we view the empowered woman as an assertive member of a farm household, and the degree of empowerment is contingent upon a woman's perceived belief in her ability to exercise control over various dimensions of agriculture (e.g., production, resources).

The importance of women's empowerment as a tool for development can be well approximated by the issue's inclusion in the United Nation's Sustainable Development Goals (SDGs), which calls for creating a conducive environment for women where they have higher decision-making power and control over political, economic and public life. Several studies [31,32] echoed this view as they reported that when women have control over cash income, expenditure patterns lean more toward human development inputs such as food and education. Duflo [33] stated that women's empowerment and economic development are bi-directional in the sense that economic development drives down gender inequality and gender bias hinder development.

One of the most well-known measures of farm households' women's empowerment is the index (WEAI) developed by Alkire et al. [10]. WEAI focuses on the agency aspect of the women's empowerment. It measures the ability of women in farm households to make decisions that relate directly to agriculture. WEAI has been used extensively in 
various studies that documented the impact of women's empowerment in agriculture on agricultural production, nutrition, and food security. For example, Sraboni et al. [34] employed WEAI to examine the relationship between women's empowerment in agriculture and per capita calorie availability, dietary diversity, and adult body mass index (BMI) in Bangladesh. Malapit et al. [35] used WEAI to investigate the relationship between women's empowerment and dietary diversity and anthropometric outcomes of mothers and children in rural Nepal. Cunningham et al. [36] examined the link between women's empowerment in agriculture and child nutritional status in rural Nepal. Malapit and Quisumbing [37] used WEAI to investigate the association between women's empowerment and the nutritional status of women and children in northern Ghana. As discussed in the previous section, some studies $[8,11,12]$ used WEAI to study the linkage between women's empowerment and technical efficiency or crop output quantity. In conclusion, the literature reviewed indicates an apparent gap in our understanding of the link between women's empowerment and farm-level productivity change. This study makes an important contribution to the literature by being the first to look at the relationship between women's empowerment and farm-level productivity and its components.

\section{Methodology}

\subsection{Conceptual framework}

Households can be viewed as a single production unit with a collective structure and members with dissimilar preferences [38,39]. This assumption of cooperative arrangements among members is more consistent as opposed to the unitary model that assumes a single set of household preference and representative altruistic household head [40,41]. Therefore, the relationship between productivity change and women's 
empowerment can be conceptualized in terms of a collective bargaining model, where a household shares a stock of resources, and the allocation and use of which is influenced by bargaining power or gendered division of preferences and weights that are being placed on different intrahousehold decisions. Seen in this light, the women's empowerment in the household corresponds to their say in household decision making and can consequently affect the outcomes, including the decisions that determine the inputs used to generate output. In the context of Bangladeshi rice-producing households, women's empowerment could affect household productivity change through the effects on the number of size of plots used, the labor applied, or other inputs purchased, but this is speculation in the absence of focused study. Several studies [41-43] indicate that women's bargaining power positively affects household outcomes such as household food security, girls' school enrollment, and children's health status. Higher food security and improved health of the household members could in turn result in a more productive workforce when household members are working at the farm, leading to higher productivity. In another example, if more empowered women are involved in economic or social groups in rural areas, they may bring ideas about new farm practices and technologies that have the potential to increase productivity through, for example, more efficient use of farm resources. In theory, at least, a shift in bargaining power might reallocate resources and effort away from agricultural output and towards other household goals that are given newfound priority, although we are not aware of any empirical finding that would support such a claim. In what follows, the empirical methods used to estimate farm household productivity change and assess the relationship between productivity change and women's empowerment are presented. 


\subsection{Empirical framework}

\subsubsection{Measuring productivity change}

Following the literature [19,24,44,45], we use the input-oriented Malmquist index to measure farm productivity change. The input orientation is appropriate since farmers have more control over inputs than outputs, which may be affected by external factors such as weather conditions. The input-oriented Malmquist index is based on the input distance function introduced by Shephard [46], which seeks the maximal proportional reduction of an observed input bundle for a given output bundle.

The production technology of a farm household using inputs $x^{t}$ in period $t$ to produce output $y^{t}$ is represented by the following technology set:

$$
T^{t}=\left\{\left(x^{t}, y^{t}\right): x^{t} \text { can produce } y^{t}\right\}
$$

Another equivalent set-wise characterization of the production technology can be given via the input requirement set of farm households as:

$$
L\left(y^{t}\right)=\left\{\left(x^{t}:\left(x^{t}, y^{t}\right) \text { is feasible }\right\}\right.
$$

The input requirement set in (2) represents all possible combinations of inputs that can produce a particular level of output.

A convenient generalization of the production technology, which is a key instrument of efficiency and productivity analysis, is the Shephard's input distance function. The Shephard's input distance function for period $t$ can be defined as:

$$
D_{i}^{t}\left(x^{t}, y^{t}\right)=\max \left\{\lambda:\left(x^{t} / \lambda\right) \in L\left(y^{t}\right)\right\}
$$

where $\lambda$ is the value of the input distance function. We can obtain $D_{i}^{t+1}\left(x^{t+1}, y^{t+1}\right)$ by substituting $t$ for $t+1 . D_{i}^{t}\left(x^{t}, y^{t}\right)$ and $D_{i}^{t+1}\left(x^{t+1}, y^{t+1}\right)$ are called single-period distance functions. One can also obtain the following mixed-period distance functions: 
$D_{i}^{t}\left(x^{t+1}, y^{t+1}\right)$ and $D_{i}^{t+1}\left(x^{t}, y^{t}\right)$. The first of these distance functions concerns the firms at time $t+1$ in relation to the technology at time $t$. The second distance function concerns the firms at time $t$ relative to the technology at time $t+1$. Färe et al. [47] used single and mixed-period distance functions to compute the Malmquist productivity index. Assuming a constant return to scale, they defined the input-oriented Malmquist index as:

$$
\mathrm{M}\left(x^{t}, y^{t}, x^{t+1}, y^{t+1}\right)=\left[\frac{D_{c}^{t}\left(x^{t+1}, y^{t+1}\right)}{D_{c}^{t}\left(x^{t}, y^{t}\right)} \times \frac{D_{c}^{t+1}\left(x^{t+1}, y^{t+1}\right)}{D_{c}^{t+1}\left(x^{t}, y^{t}\right)}\right]^{1 / 2},
$$

where $M$ is the input-oriented productivity index, which quantifies the changes in productivity originating from the efficiency change measured under period $t$ technology and from the efficiency change measured under period $t+1$ technology. Following Ray and Desli [48], assuming a variable returns to scale (subscript v stands for VRS and c stands for CRS), we decompose the Malmquist index into efficiency change (EC), technical change (TC), and scale efficiency (SE) change:

$$
\begin{gathered}
M\left(x^{t}, y^{t}, x^{t+1}, y^{t+1}\right)=\underbrace{\frac{D_{v}^{t+1}\left(x^{t+1}, y^{t+1}\right)}{D_{v}^{t}\left(x^{t}, y^{t}\right)}}_{E C} \times \underbrace{\left[\frac{D_{v}^{t}\left(x^{t+1}, y^{t+1}\right)}{D_{v}^{t+1}\left(x^{t+1}, y^{t+1}\right)} \times \frac{D_{v}^{t}\left(x^{t}, y^{t}\right)}{D_{v}^{t+1}\left(x^{t}, y^{t}\right)}\right]^{1 / 2}}_{T C} \\
\times \underbrace{\left[\frac{D_{c}^{t+1}\left(x^{t+1}, y^{t+1}\right) / D_{v}^{t+1}\left(x^{t+1}, y^{t+1}\right)}{D_{c}^{t+1}\left(x^{t}, y^{t}\right) / D_{v}^{t+1}\left(x^{t}, y^{t}\right)} \times \frac{D_{c}^{t}\left(x^{t+1}, y^{t+1}\right) / D_{v}^{t}\left(x^{t+1}, y^{t+1}\right)}{D_{c}^{t}\left(x^{t}, y^{t}\right) / D_{v}^{t}\left(x^{t}, y^{t}\right)}\right]^{1 / 2}}_{S E} \\
=E C_{i}\left(x^{t}, y^{t}, x^{t+1}, y^{t+1}\right) \times T C_{i}\left(x^{t}, y^{t}, x^{t+1}, y^{t+1}\right) \\
\times S E_{i}\left(x^{t}, y^{t}, x^{t+1}, y^{t+1}\right)
\end{gathered}
$$

EC is the relative efficiency change index which measures catch-up or the degree to which a Decision-Making Unit (DMU) improves or worsens its efficiency relative to the DMUs in the best practice frontier. It reflects a DMU's ability to use the available knowledge and technology to reach the best practice frontier. TC, often termed interchangeably with 
technological change, indicates the frontier shift reflecting changes in the efficient frontiers between two time periods. Therefore, TC represents a DMU's level of innovativeness. SE change measures the closeness of a DMU to its most efficient (optimal) scale size. Technically, it may be interpreted as the relative contraction of inputs by producing at optimal scale on the best practice frontier for the observed input mix of a DMU whose technical inefficiency has been eliminated. Or geometrically, it may be defined as the ray average productivity after the observed mixture of inputs is projected to the best practice frontier relative to what is achievable at the optimal scale [49]. Values of $M(\cdot)$ or any of its components greater (less) than one implies productivity regress (improvement). Following Odeck [50], for the ease of interpretation, we take the inverse of productivity scores and its components, such that an index greater (less) than one implies productivity improvement (regress).

The distance functions defined above are empirically estimated using Data Envelopment Analysis. More specifically the distance function $D_{i}^{t}\left(x^{t}, y^{t}\right)$ is calculated by solving the following linear problem:

$\left[D_{i}^{t}\left(x^{t}, y^{t}\right)\right]^{-1}=\min _{\lambda, \theta} \lambda$

subject to

$$
\begin{aligned}
& y_{m 0}^{t} \leq \sum_{i=1}^{k} \theta_{i} y_{m i}^{t}, \quad m=1,2, \ldots, M \\
& \lambda x_{n 0}^{t} \geq \sum_{i=1}^{k} \theta_{i} x_{n i}^{t}, \quad n=1,2, \ldots, N \\
& \theta_{i} \geq 0, \quad s=1,2, \ldots, S \\
& \sum_{i=1}^{K} \theta_{i}=1,
\end{aligned}
$$


where $\lambda$ is a scalar that represents the efficiency score for the $i^{\text {th }}$ household, and $\theta$ are household weights that define the best practice frontier. In a similar way, $D_{i}^{t+1}\left(x^{t+1}, y^{t+1}\right)$ is computed by substituting $t$ for $t+1$.

The mixed period distance function $D_{i}^{t}\left(x^{t+1}, y^{t+1}\right)$ which calculates the efficiency of firms observed in period $t+1$ relative to the period $t$ technology is given by: $\left[D_{i}^{t}\left(x^{t+1}, y^{t+1}\right)\right]^{-1}=\min _{\lambda, \theta} \lambda$

subject to

$$
\begin{aligned}
& y_{m 0}^{t+1} \leq \sum_{i=1}^{k} \theta_{i} y_{m i}^{t}, m=1,2, \ldots, M \\
& \lambda x_{n 0}^{t+1} \geq \sum_{i=1}^{k} \theta_{i} x_{n i}^{t}, \quad n=1,2, \ldots, N \\
& \theta_{i} \geq 0, \quad s=1,2, \ldots, S \\
& \sum_{i=1}^{K} \theta_{i}=1
\end{aligned}
$$

The mixed period distance function $D_{i}^{t+1}\left(x^{t}, y^{t}\right)$ is obtained analogously.

3.2.2. Modeling the relationship between productivity change and women's empowerment

After computing the household-specific TFP growth and its components, we use the following model to examine the association between productivity change and women's empowerment (and a set of control variables):

$$
y_{i}=\alpha+z_{i} \beta+u_{i}
$$

where, $y_{i}$ is the input-oriented Malmquist productivity change (or its components) for household $i, \alpha$ is an intercept and $z_{i}$ is the base period vector of exogenous independent 
variables that represents women's empowerment measures, and other control variables for the household $i, \beta$ is the vector of coefficients to be estimated and $u_{i}$ is an error term.

We follow the non-parametric bootstrap method of Kapelko et al. [51], as summarized here. We estimate equation (8) using an OLS bootstrap regression. A bootstrap regression is required to address the well-known problem of serial correlation among nonparametrically derived productivity and efficiency scores. This approach is a standard nonparametric bootstrap that involves randomly drawing, with replacement, a large number of subsamples from the original sample, and allows the computation of bootstrap regression coefficients and confidence intervals. Our computations involved 5,000 bootstrap replicates. Equation (8) was estimated separately for productivity change and each of its components.

\subsubsection{Endogeneity issues}

Two endogeneity issues complicate the estimation of the relationship between women's empowerment and productivity change. The first one is simultaneity or reverse causation. As Wouterse [12] argues, higher empowerment could increase productivity, but at the same time, higher productivity may result in higher income levels, and as a result, enhance household members' empowerment. However, we believe simultaneity is not an issue in our research setting because we use the base period WEAI as an explanatory variable in eq. (8). Therefore, the initial status of a woman in a household is exogenous with respect to how much productivity changes after the initial condition. The second endogeneity issue is omitted variable bias. Given that the WEAI indicators considered here are perceived measures of a woman's ability to exercise control over various dimensions of agriculture, there might be unobserved factors determining both the empowerment in 
the base year and productivity change. To empirically address the potential endogeneity of WEAI variables, a Wu-Hausman test for exogeneity of these variables was conducted [52]. Following Diiro et al. [11], domestic violence, dependency ratio, and age and education differences between the principal male respondent and principal female respondent in the household were used to instrument for the WEAI variables. As it will be discussed in more detail in the results section, the Wu-Hausman test results support the exogeneity of WEAI variables. However, recognizing that the used instruments are unlikely to respect the exclusion restriction and better instruments could not be found, it is appropriate to exercise caution when it comes to attributing causality. As a consequence, in this article we speak of association (or correlation) rather than causation.

\section{Data}

The data used in this study is taken from Bangladesh Integrated Household Survey (BIHS). BIHS is a nationally representative survey in Bangladesh with multiple rounds ${ }^{\mathrm{iii}}$, of which the 2011/12 and 2015/16 rounds are available at this time (see Ahmed [53] for details). By using a two-stage stratified sampling technique and a sampling frame developed from the community series of the 2001 population census of Bangladesh, BIHS collects detailed data on (1) plot-level agricultural production and practices, (2) dietary intake of individual household members, (3) anthropometric measurements (height and weight) of all household members, and (4) WEAI. BIHS includes 6,500 households in 325 Primary Sampling Units (PSUs) or villages. This study focuses on farms engaged primarily in rice production, and for this purpose, we have selected households ${ }^{\mathrm{iv}}$ whose value of total rice production is at least $80 \%$ of their total annual farm revenue and participated in both survey rounds. Some variables in the dataset are reported at the plot-level. Other variables, 
including rice output, capital assets, and women's empowerment, are reported for each household, which precludes a plot-level analysis. And, fundamentally, our research question is about the association of women's empowerment and household productivity change, so we do not focus on plot productivity nor, in any case, can we know the variation in women's empowerment as it relates to individual plots from these survey data. As a result, plot-level information was aggregated to the household-level. Although the survey asks about plots, we cannot track plots between survey rounds. The final dataset consists of a balanced panel of 1,197 households with a total of 2,394 observations ${ }^{\mathrm{v}}$.

The data needed to compute the input distance functions in equation (6) and (7) (that are in turn used to calculate the Malmquist productivity index and its components) include one output and four inputs (Table 1). The output variable includes rice that is produced and either sold or used in the household itself, with the total value of these two uses divided by the consumer price index (CPI)-food [54] to find the total volume as an implicit quantity index. The input variables consist of land, labor, capital and equipment, and miscellaneous input expenses. Land is measured as the total area of cultivable/arable plots (owned or otherwise) used by each household. Labor is the total annual hours of hired and family labor. Capital and equipment are defined as the value of farming tools, machinery, and other tools used in the production process, and is readily available at the household level. Finally, miscellaneous expenses include the value of variable expenses such as seed, irrigation, agrochemicals, and other expenses. All monetary inputs (i.e., capital and miscellaneous inputs) were transformed to implicit quantity indices by calculating the ratio of value to the Bangladesh CPI-Food, with base period being that of 2005/06. 
Table 1. Summary statistics of the deflated outputs and inputs of the sample households

\begin{tabular}{llrrrr}
\hline $\mathbf{2 0 1 1}$ & & & & & \\
\hline Variables & Unit & Mean & Std. Dev & Min & Max \\
\hline Output & Taka* & 26,485 & 27,803 & 544 & 26,7488 \\
Land & Decimal & 131 & 137 & 4 & 1,620 \\
Labor & Hours & 484 & 463 & 30 & 6,304 \\
Capital and equipment & Taka* & 5,287 & 26,324 & 5 & 491,450 \\
Miscellaneous expenses & Taka* & 4,798 & 4,527 & 207 & 39,271 \\
\hline 2014 & & & & & \\
\hline Variables & Unit & Mean & Std. Dev & Min & Max \\
\hline Output & Taka* & 24,436 & 27,117 & 227 & 276,017 \\
Land & Decimal & 135 & 145 & 3 & 1,665 \\
Labor & Hours & 599 & 581 & 15 & 7,435 \\
Capital and equipment & Taka* & 5,988 & 29,720 & 9 & 867,542 \\
Miscellaneous expenses & Taka* & 7,526 & 7,571 & 56 & 92,308 \\
\hline Source: Authors' calculations & Note: The asterisk superscript $\left.*^{*}\right)$ denotes an implicit quantity index measured in constant $2005 / 06$ & prices
\end{tabular}

Concerning the data used in the second stage of our analysis, the $z_{i}$ vector in equation (8) includes a household-specific women's empowerment measure (e.g., women's empowerment score, gender parity gap, individual empowerment domains, or empowerment indicators), and a set of control variables. The following subsections describe the procedure followed to calculate the different women's empowerment measures for each household and the variables included in the control variables.

\subsection{Women's empowerment in agriculture measures}

The women's empowerment in agriculture measures used in this study are based on the women's empowerment in agriculture index (WEAI) developed by Alkire et al. [10]. WEAI is a survey-based index that measures empowerment, agency, and inclusion of women in agriculture. WEAI is an aggregate measure with two sub-indices namely five domains of empowerment (5DE) and gender parity index (GPI). 
The first index, 5DE (empowerment score thereafter), is an estimation of respondents' empowerment score based on their role in five domains of agricultural decision making (Table 2). An individual-level questionnaire (see Alkire et al. [55] for details) is used as the primary instrument to measure empowerment using weighted domain-specific indicators. For example, group membership indicator, of the leadership domain, is given a weight of 0.10 , and this weight relates to questions about membership in economic or social groups. If the respondent reports membership in at least one economic or social group, she scores 0.10 under this indicator. The empowerment score is calculated similarly for the other nine indicators, and a composite empowerment score is then generated by taking the weighted sum of all ten indicators. By construction, the empowerment score ranges from 0 to 1 . Alkire et al. [10] judge that a score of 0.80 or more in the composite scale is required to deem a woman as empowered. The second index, GPI, is the relative measure of inequality and estimated using the difference between 5DE scores of each household's primary adult male and female. The gender parity gap (empowerment gap thereafter) takes a value of zero if the primary female decision maker's 5DE score exceeds or is equal to that of primary male decision maker. This measure reflects the relative empowerment of the women compared to the men in decision making. Gender parity is achieved when the empowerment score of the primary female meets or exceeds the empowerment score of the primary male living in the same household. 
Table 2. WEAI domains

\begin{tabular}{|c|c|c|c|}
\hline Domain & Indicator & Description & Weight \\
\hline \multirow[t]{2}{*}{ Production } & $\begin{array}{l}\text { Input in productive } \\
\text { decisions }\end{array}$ & $\begin{array}{l}\text { Ability to make decisions (sole or joint) } \\
\text { about food and cash-crop farming, } \\
\text { livestock, and fisheries }\end{array}$ & $1 / 10$ \\
\hline & $\begin{array}{l}\text { Autonomy in } \\
\text { production }\end{array}$ & $\begin{array}{l}\text { Ability to act according to own value and } \\
\text { judgment regarding inputs to buy, types of } \\
\text { crops to grow, when to take or who would } \\
\text { take crops to market, and livestock } \\
\text { production }\end{array}$ & $1 / 10$ \\
\hline \multirow[t]{3}{*}{ Resources } & $\begin{array}{l}\text { Ownership of } \\
\text { assets }\end{array}$ & $\begin{array}{l}\text { Sole or joint ownership of household assets } \\
\text { such as land, livestock, consumer durables, } \\
\text { agricultural equipment }\end{array}$ & $1 / 15$ \\
\hline & $\begin{array}{l}\text { Purchase, sale, or } \\
\text { transfer of assets }\end{array}$ & $\begin{array}{l}\text { Decision-making authority over the } \\
\text { purchase, sale, or transfer of household } \\
\text { assets }\end{array}$ & $1 / 15$ \\
\hline & $\begin{array}{l}\text { Access to and } \\
\text { decisions about } \\
\text { credit }\end{array}$ & $\begin{array}{l}\text { Decision-making authority over obtaining } \\
\text { credit and using credit proceeds }\end{array}$ & $1 / 15$ \\
\hline Income & $\begin{array}{l}\text { Control over the } \\
\text { use of income }\end{array}$ & $\begin{array}{l}\text { Sole or joint control over income and } \\
\text { expenditures }\end{array}$ & $1 / 5$ \\
\hline \multirow[t]{2}{*}{ Leadership } & Group membership & $\begin{array}{l}\text { Active membership in at least one } \\
\text { economic or social group }\end{array}$ & $1 / 10$ \\
\hline & Speaking in public & $\begin{array}{l}\text { Ability to speak up in public for reasons } \\
\text { like to ensure proper payment of wages for } \\
\text { public work programs, to protest the } \\
\text { misbehavior of authorities or to help decide } \\
\text { on infrastructure }\end{array}$ & $1 / 10$ \\
\hline \multirow[t]{2}{*}{ Time } & Workload & $\begin{array}{l}\text { The productive and domestic workload in a } \\
\text { 24-hour framework }\end{array}$ & $1 / 10$ \\
\hline & Leisure & $\begin{array}{l}\text { Subjective satisfaction with available } \\
\text { leisure time }\end{array}$ & $1 / 10$ \\
\hline
\end{tabular}

Source: Alkire et al. [10]

WEAI operates under predetermined assumptions to capture the power dynamics

of the farm household's women. Such dynamics may alter under much wider or restrictive assumptions. For example, under the leisure indicator, a woman is deemed as empowered if she is at least neither satisfied nor dissatisfied with the time available for leisure. One might argue that such a definition of empowerment (related to leisure time) is not the true 
depiction of empirical reality because the assumption does not distinguish between satisfaction and dissatisfaction with available leisure time, nor does it reward a reported higher level of satisfaction with a larger scale. Such variation in the subjective assessment of empowerment will result in different estimates of empowerment score. We capitalized on this idea and developed two alternative empowerment scoring approaches by modifying the WEAI assumptions to refocus this variable on our specific requirements (see online supplement S1 for more details). A summary of the alternative measures used to represent women's empowerment in agriculture is given in Table 3.

\section{Table 3. Summary statistics of WEAI and alternative empowerment measures}

\begin{tabular}{|c|c|c|c|c|c|c|c|c|c|c|c|c|}
\hline \multirow[b]{3}{*}{$\begin{array}{l}\text { Empowerment } \\
\text { score }\end{array}$} & \multicolumn{4}{|c|}{$\begin{array}{l}\text { WEAI- Based on Alkire et } \\
\text { al. }[10]\end{array}$} & \multicolumn{4}{|c|}{ Alternative approach 1} & \multicolumn{4}{|c|}{ Alternative approach 2} \\
\hline & Mean & $\begin{array}{l}\text { Std. } \\
\text { dev }\end{array}$ & Min & Max & Mean & $\begin{array}{l}\text { Std. } \\
\text { dev }\end{array}$ & Min & Max & Mean & $\begin{array}{l}\text { Std. } \\
\text { dev }\end{array}$ & Min & Max \\
\hline & 0.60 & 0.19 & 0.10 & 1.00 & 0.30 & 0.12 & 0.03 & 0.72 & 0.53 & 0.16 & 0.09 & 0.97 \\
\hline $\begin{array}{l}\text { Empowerment } \\
\text { gap }\end{array}$ & 0.15 & 0.17 & 0.00 & 0.80 & 0.10 & 0.11 & 0.00 & 0.62 & 0.14 & 0.15 & 0.00 & 0.82 \\
\hline \multicolumn{13}{|l|}{ Domains } \\
\hline Production & 0.10 & 0.07 & 0.00 & 0.20 & 0.07 & 0.06 & 0.00 & 0.20 & 0.11 & 0.06 & 0.00 & 0.20 \\
\hline Resources & 0.13 & 0.06 & 0.00 & 0.20 & 0.03 & 0.02 & 0.00 & 0.11 & 0.11 & 0.06 & 0.00 & 0.20 \\
\hline Income & 0.15 & 0.08 & 0.00 & 0.20 & 0.05 & 0.04 & 0.00 & 0.20 & 0.12 & 0.06 & 0.00 & 0.20 \\
\hline Leadership & 0.06 & 0.07 & 0.00 & 0.20 & 0.01 & 0.02 & 0.00 & 0.11 & 0.04 & 0.05 & 0.00 & 0.20 \\
\hline Time & 0.15 & 0.06 & 0.00 & 0.20 & 0.12 & 0.06 & 0.00 & 0.20 & 0.15 & 0.06 & 0.00 & 0.20 \\
\hline
\end{tabular}

Under the first alternative approach, we developed empowerment scores based on the gradations of women's power rather than binary assessments. The second alternative approach focuses on a woman's engagement and relative input in the activity or decisionmaking process in which a household participates. For each of these approaches, scores of empowerment, gender parity gap, individual empowerment domains, and indicators were calculated. The objective behind the formulation of alternatives scores is to improve the tests for an association between women's empowerment and the productivity change of 
rice farms in Bangladesh. We can affirm our findings as robust and valid only when the underlying effect estimates remain consistent under different subjective ratings of the empowerment concept. We posit that construction of alternative indices using a single standardized framework that solely focus on agency aspect of women's empowerment runs the risk of ignoring indirect indicators such as resources and achievements. However, the design and implementation of indicators of women's empowerment is beyond the scope of this study. Hence, we followed the framework suggested by Alkire et al. [10] and recalculate the index by testing different assumptions regarding the adequacy requirements. Despite the shortcomings, such assumptions allow us to capture different contexts that different households may encounter and measure multidimensional characteristics of women's empowerment at various levels of aggregation.

\subsection{Control variables}

The selection of control variables included in equation (8) was guided by data availability and previous studies on the determinants of farm productivity $[5,18,20]$. These variables include sex, age, education, dependency ration, household size, extension visit, rainfed, tenancy, income share from non-agricultural enterprise, rainfall, temperature, and locational dummies. ${ }^{\mathrm{vi}}$ Table 4 presents the definition and summary statistics of these variables. 
Table 4. Control variables and descriptive statistics

\begin{tabular}{|c|c|c|c|c|c|}
\hline Variables & Description & Mean & $\begin{array}{l}\text { Std. } \\
\text { dev }\end{array}$ & Min & Max \\
\hline Sex & Categorical: one if female else zero & 0.02 & 0.14 & 0.00 & 1.00 \\
\hline Age & Primary respondent's age & 46.37 & 12.46 & 18.00 & 85.00 \\
\hline Education & $\begin{array}{l}\text { Years of education completed by the } \\
\text { primary respondent }\end{array}$ & 3.23 & 3.92 & 0.00 & 16.00 \\
\hline $\begin{array}{l}\text { Dependency } \\
\text { ratio }\end{array}$ & $\begin{array}{l}\text { The ratio of children ( } 0-14 \text { years } \\
\text { old) and nonworking-age household } \\
\text { members ( } 65 \text { years or older) to } \\
\text { working-age household members } \\
\text { (15-64 years old) }\end{array}$ & 0.76 & 0.60 & 0.00 & 5.00 \\
\hline $\begin{array}{l}\text { Household } \\
\text { size }\end{array}$ & Total members in the household & 4.69 & 1.68 & 2.00 & 14.00 \\
\hline Extension visit & $\begin{array}{l}\text { Number of visits by an agricultural } \\
\text { extension agent to the household or } \\
\text { by a household member to an } \\
\text { extension service office during the } \\
\text { last } 12 \text { months }\end{array}$ & 0.35 & 1.32 & 0.00 & 15.00 \\
\hline Rainfed & $\begin{array}{l}\text { Categorical: one if rain is the } \\
\text { primary source of water for } \\
\text { cultivation else zero }{ }^{\text {vii }}\end{array}$ & 0.37 & 0.48 & 0.00 & 1.00 \\
\hline Tenancy & $\begin{array}{l}\text { Categorical: one if the land is taken- } \\
\text { in through a cash lease or crop- } \\
\text { sharing arrangement else zero }{ }^{\text {viii }}\end{array}$ & 0.33 & 0.47 & 0.00 & 1.00 \\
\hline $\begin{array}{l}\text { Non-agri. } \\
\text { income share }\end{array}$ & $\begin{array}{l}\text { Share of household income from } \\
\text { non-agricultural sources }\end{array}$ & 0.22 & 0.31 & 0.00 & 1.00 \\
\hline Rainfall & $\begin{array}{l}\text { Difference between the average } \\
\text { annual rainfall of crop cultivation } \\
\text { years } 2014 \text { and } 2011 \text { (in millimeters) }\end{array}$ & -224.99 & 299.31 & -487.00 & 349.00 \\
\hline Temperature & $\begin{array}{l}\text { Difference between the average of } \\
\text { minimum and maximum } \\
\text { temperature of crop cultivation year } \\
2014 \text { and } 2011 \text { (in Celsius) }\end{array}$ & 0.43 & 0.20 & 0.20 & 0.80 \\
\hline Northwest & $\begin{array}{l}\text { Categorical: one if northwest } \\
\text { divisions else zero }\end{array}$ & 0.20 & 0.40 & 0.00 & 1.00 \\
\hline Southwest & $\begin{array}{l}\text { Categorical: one if southwest } \\
\text { divisions else zero }\end{array}$ & 0.23 & 0.42 & 0.00 & 1.00 \\
\hline Northeast & $\begin{array}{l}\text { Categorical: one if northeast } \\
\text { divisions else zero }\end{array}$ & 0.15 & 0.36 & 0.00 & 1.00 \\
\hline
\end{tabular}

Source: Authors' calculations

Note: Rainfall and temperature data are collected from the yearbook of agricultural statistics -2014 (56). 


\section{Results}

The Malmquist productivity index and its decomposition are summarized in Table

5. Before discussing these results, it should be noted that the mixed-period linear programs used to calculate the Malmquist productivity index and its components may give infeasible solutions. A possible remedy to this problem is to exclude the observations with infeasible solutions from the calculation of average productivity change and its components [51]. Briec and Kerstens [57] argue that studies computing productivity indices using nonparametric estimators should report the infeasibilities resulting from the estimation of the mixed-period distance functions. In our case, out of 1,197 observations, only one observation has an infeasible solution for one of the mixed period distance functions. This observation was excluded in the second stage analysis.

Over the estimation period, on average, productivity fell by $24 \%$, technical efficiency grew by $15 \%$, technological change fell by $35 \%$, and scale efficiency grew by 3\%. Putting these results in perspective with that of other studies from Bangladesh agriculture, we see that our estimate of productivity decrease is more severe than that of Coelli et al. [21], who reported a $0.23 \%$ decline in productivity, and contrasts with increases reported by Hossain et al. [20], at 2.95\%, and Rahman and Salim [19], at 0.57\%. However, the findings of this study are not directly comparable to those studies due to the difference in the sample. This study uses plot-level data (aggregated to household level), whereas the aforementioned studies used regional level data. Other notable differences include crop type analyzed (e.g., Coelli et al. [21] aggregated food and cash crops) and estimation method employed (e.g., Rahman and Salim [19] used the Färe-Primont index to measure productivity). 
Table 5. Average Malmquist productivity index and its components of the sample households for the period 2011-2014

\begin{tabular}{lrrrr}
\hline & $\begin{array}{r}\text { Productivity } \\
\text { change }\end{array}$ & $\begin{array}{r}\text { Efficiency } \\
\text { change }\end{array}$ & $\begin{array}{r}\text { Technical } \\
\text { change }\end{array}$ & $\begin{array}{r}\text { Scale efficiency } \\
\text { change }\end{array}$ \\
\hline Mean & 0.76 & 1.15 & 0.65 & 1.03 \\
Std. Dev. & 0.40 & 0.57 & 0.10 & 0.21 \\
Min & 0.12 & 0.13 & 0.29 & 0.62 \\
Max & 3.78 & 4.35 & 2.10 & 6.93 \\
$95 \%$ Conf. Interval & & & & \\
Lower bound & 0.73 & 1.12 & 0.64 & 1.02 \\
Upper bound & 0.78 & 1.18 & 0.65 & 1.04 \\
\hline Source: Authors' calculations & & & &
\end{tabular}

Decomposition results indicate that productivity in Bangladesh rice farming fell due entirely to the decline in technical change. Shifts in technical change can be considered to be evidence of innovation [58]. In the simplest analysis, lack of innovation in the current production technology or the adoption of a production technology that is not innovative enough to reflect the needs of the farmers might cause a decline in technical change, which in turn contributes to overall productivity decline. While we are unable to identify the precise reason for such a big drop in technical change, it seems that the increase in miscellaneous expenses, specifically, fourfold increase in rental cost which includes cost of tools, fuels, machinery, and draft Animal, has negatively affected the direction of technical frontier. Another potential cause of technological regress could be declining soil quality, with evidence suggesting that cropping practices reduce soil organic matter with negative impacts on Bangladesh rice production [59-61]. 
Table 6. Results of the OLS bootstrap regression of the determinants of farm productivity change and its components

\begin{tabular}{|c|c|c|c|c|c|c|c|c|c|c|c|c|}
\hline \multirow[b]{2}{*}{ Variables } & \multicolumn{4}{|c|}{$\begin{array}{l}\text { Model 1: Empowerment score based on } \\
\text { Alkire et al. [10] }\end{array}$} & \multicolumn{4}{|c|}{$\begin{array}{l}\text { Model 2: Alternative empowerment score based } \\
\text { on approach } 1\end{array}$} & \multicolumn{4}{|c|}{$\begin{array}{l}\text { Model 2: Alternative empowerment score based } \\
\text { on approach } 2\end{array}$} \\
\hline & $\begin{array}{l}\text { Productivity } \\
\text { change }\end{array}$ & $\begin{array}{l}\text { Efficiency } \\
\text { change }\end{array}$ & $\begin{array}{l}\text { Technical } \\
\text { change }\end{array}$ & $\begin{array}{l}\text { Scale } \\
\text { efficiency } \\
\text { change }\end{array}$ & $\begin{array}{l}\text { Productivity } \\
\text { change }\end{array}$ & $\begin{array}{l}\text { Efficiency } \\
\text { change }\end{array}$ & $\begin{array}{l}\text { Technical } \\
\text { change }\end{array}$ & $\begin{array}{l}\text { Scale } \\
\text { efficiency } \\
\text { change }\end{array}$ & $\begin{array}{l}\text { Productivity } \\
\text { change }\end{array}$ & $\begin{array}{l}\text { Efficiency } \\
\text { change }\end{array}$ & $\begin{array}{l}\text { Technical } \\
\text { change }\end{array}$ & $\begin{array}{l}\text { Scale } \\
\text { efficiency } \\
\text { change }\end{array}$ \\
\hline \multirow{4}{*}{$\begin{array}{l}\text { Empowerment } \\
\text { score } \\
\text { Sex }\end{array}$} & $0.169 * * *$ & $0.166^{*}$ & $0.038^{* *}$ & -0.017 & $0.438 * * *$ & $0.460 * * *$ & $0.075 * * *$ & 0.041 & $0.251 * * *$ & $0.292 * * *$ & $0.038 * *$ & -0.018 \\
\hline & $(0.060)$ & $(0.088)$ & $(0.017)$ & $(0.024)$ & $(0.111)$ & $(0.157)$ & $(0.024)$ & $(0.063)$ & $(0.079)$ & $(0.112)$ & $(0.019)$ & (0.027) \\
\hline & -0.107 & -0.096 & $-0.037 *$ & 0.019 & $-0.128 *$ & -0.119 & $-0.039 * *$ & 0.015 & $-0.124 *$ & -0.119 & $-0.038 *$ & 0.020 \\
\hline & $(0.070)$ & $(0.108)$ & $(0.020)$ & $(0.025)$ & $(0.071)$ & $(0.112)$ & $(0.019)$ & $(0.026)$ & (0.069) & $(0.108)$ & $(0.020)$ & $(0.026)$ \\
\hline \multirow[t]{2}{*}{ Age } & 0.001 & 0.001 & 0.000 & 0.000 & 0.001 & 0.001 & 0.000 & 0.000 & 0.001 & 0.001 & 0.000 & 0.000 \\
\hline & $(0.001)$ & $(0.001)$ & $(0.000)$ & $(0.000)$ & $(0.001)$ & $(0.001)$ & $(0.000)$ & $(0.000)$ & $(0.001)$ & $(0.001)$ & $(0.000)$ & $(0.000)$ \\
\hline \multirow[t]{2}{*}{ Education } & 0.001 & -0.004 & $0.001^{*}$ & $0.004 *$ & 0.000 & -0.005 & $0.001 *$ & $0.004 *$ & 0.001 & -0.005 & $0.001 *$ & $0.004 *$ \\
\hline & $(0.003)$ & $(0.005)$ & $(0.001)$ & $(0.002)$ & $(0.003)$ & (0.005) & $(0.001)$ & $(0.002)$ & $(0.003)$ & $(0.005)$ & $(0.001)$ & (0.002) \\
\hline \multirow[t]{2}{*}{ Dependency ratio } & $-0.047 * *$ & $-0.055^{* *}$ & -0.007 & -0.006 & $-0.045 * *$ & $-0.052 *$ & -0.007 & -0.006 & $-0.046^{* *}$ & $-0.054 *$ & -0.007 & -0.006 \\
\hline & $(0.019)$ & $(0.028)$ & $(0.005)$ & $(0.011)$ & $(0.019)$ & $(0.028)$ & $(0.005)$ & $(0.011)$ & $(0.019)$ & $(0.028)$ & $(0.005)$ & $(0.011)$ \\
\hline \multirow[t]{2}{*}{ Household size } & -0.014 & $-0.019 *$ & 0.001 & $-0.005 * *$ & -0.013 & $-0.019 *$ & 0.001 & $-0.005 * *$ & -0.013 & $-0.019 *$ & 0.001 & $-0.005 * *$ \\
\hline & $(0.009)$ & $(0.011)$ & $(0.002)$ & $(0.003)$ & $(0.009)$ & $(0.012)$ & $(0.002)$ & $(0.002)$ & $(0.009)$ & $(0.011)$ & $(0.003)$ & $(0.002)$ \\
\hline \multirow[t]{2}{*}{ Extension visit } & 0.013 & -0.004 & 0.007 & 0.004 & 0.013 & -0.004 & 0.007 & 0.004 & 0.013 & -0.004 & 0.007 & 0.004 \\
\hline & $(0.021)$ & $(0.013)$ & $(0.009)$ & $(0.004)$ & $(0.021)$ & $(0.013)$ & $(0.010)$ & $(0.004)$ & $(0.021)$ & $(0.013)$ & $(0.010)$ & $(0.004)$ \\
\hline Income share from & 0.050 & $0.111 * *$ & -0.011 & -0.010 & 0.048 & $0.108^{*}$ & -0.011 & -0.011 & 0.051 & $0.111 * *$ & -0.010 & -0.010 \\
\hline non ag. enterprise & $(0.037)$ & $(0.055)$ & $(0.009)$ & $(0.017)$ & $(0.036)$ & $(0.055)$ & $(0.009)$ & $(0.018)$ & $(0.037)$ & $(0.055)$ & $(0.009)$ & $(0.018)$ \\
\hline \multirow[t]{2}{*}{ Rainfed } & 0.020 & 0.026 & 0.001 & -0.004 & 0.027 & 0.033 & 0.002 & -0.004 & 0.022 & 0.028 & 0.001 & -0.004 \\
\hline & $(0.025)$ & $(0.035)$ & $(0.006)$ & $(0.012)$ & $(0.024)$ & $(0.035)$ & $(0.006)$ & $(0.011)$ & $(0.025)$ & $(0.035)$ & $(0.006)$ & $(0.012)$ \\
\hline \multirow[t]{2}{*}{ Tenancy } & $0.060 * *$ & 0.059 & $0.012 * *$ & 0.011 & $0.058 * *$ & 0.057 & $0.012 * *$ & 0.011 & $0.059 * *$ & 0.057 & $0.012 * *$ & 0.011 \\
\hline & $(0.026)$ & $(0.037)$ & $(0.005)$ & $(0.017)$ & $(0.025)$ & $(0.037)$ & $(0.005)$ & $(0.017)$ & $(0.026)$ & $(0.037)$ & $(0.005)$ & $(0.017)$ \\
\hline \multirow[t]{2}{*}{ Rainfall } & $-0.000^{*}$ & -0.000 & $-0.000 * * *$ & $0.000^{*}$ & -0.000 & -0.000 & $-0.000 * * *$ & $0.000^{*}$ & $-0.000 *$ & -0.000 & $-0.000 * * *$ & $0.000^{*}$ \\
\hline & $(0.000)$ & $(0.000)$ & $(0.000)$ & $(0.000)$ & $(0.000)$ & $(0.000)$ & $(0.000)$ & $(0.000)$ & $(0.000)$ & $(0.000)$ & $(0.000)$ & $(0.000)$ \\
\hline \multirow[t]{2}{*}{ Temperature } & $0.261 * * *$ & $0.237 *$ & $0.073 * * *$ & -0.010 & $0.258 * * *$ & $0.236^{*}$ & $0.071 * * *$ & -0.003 & $0.262 * * *$ & $0.244 *$ & $0.070 * * *$ & -0.009 \\
\hline & $(0.091)$ & $(0.135)$ & $(0.024)$ & $(0.027)$ & $(0.089)$ & $(0.133)$ & $(0.023)$ & $(0.025)$ & $(0.090)$ & $(0.134)$ & $(0.024)$ & $(0.026)$ \\
\hline \multirow[t]{2}{*}{ Northwest } & 0.041 & -0.011 & $0.026^{* * *}$ & 0.034 & 0.054 & 0.004 & $0.028 * * *$ & 0.037 & 0.045 & -0.004 & $0.026^{* * *}$ & 0.034 \\
\hline & $(0.034)$ & $(0.047)$ & $(0.008)$ & $(0.024)$ & $(0.033)$ & (0.048) & $(0.008)$ & $(0.026)$ & $(0.034)$ & $(0.048)$ & $(0.008)$ & $(0.024)$ \\
\hline \multirow[t]{2}{*}{ Southwest } & -0.043 & 0.003 & $-0.028 * * *$ & -0.000 & -0.025 & 0.023 & $-0.025^{* *}$ & 0.003 & -0.039 & 0.010 & $-0.028 * * *$ & -0.000 \\
\hline & $(0.038)$ & $(0.054)$ & $(0.010)$ & $(0.010)$ & (0.037) & (0.054) & $(0.011)$ & $(0.011)$ & $(0.038)$ & $(0.053)$ & $(0.011)$ & $(0.010)$ \\
\hline \multirow[t]{2}{*}{ Northeast } & $0.171 * * *$ & $0.157 *$ & $0.054 * * *$ & -0.025 & $0.175 * * *$ & $0.162 *$ & $0.054 * * *$ & -0.022 & $0.177 * * *$ & $0.165^{*}$ & $0.054 * * *$ & -0.025 \\
\hline & $(0.059)$ & $(0.087)$ & $(0.015)$ & $(0.022)$ & $(0.058)$ & (0.087) & $(0.015)$ & $(0.022)$ & $(0.057)$ & $(0.088)$ & $(0.015)$ & $(0.022)$ \\
\hline \multirow[t]{2}{*}{ Constant } & $0.510 * * *$ & $0.977 * * *$ & $0.556^{* * *}$ & $1.063 * * *$ & $0.480 * * *$ & $0.937 * * *$ & $0.557 * * *$ & $1.037 * * *$ & $0.476 * * *$ & $0.915 * * *$ & $0.559 * * *$ & $1.062 * * *$ \\
\hline & $(0.092)$ & $(0.136)$ & $(0.024)$ & $(0.037)$ & $(0.089)$ & $(0.130)$ & $(0.022)$ & $(0.032)$ & $(0.095)$ & $(0.137)$ & $(0.024)$ & $(0.036)$ \\
\hline
\end{tabular}

Source: Authors' calculations

Note: Standard errors in parentheses; *,**, and *** indicate significance based on $90 \%, 95 \%$ and $99 \%$ bootstrap confidence level, respectively 
In the second stage, we estimated several specifications of equation (8) to analyze the relationship between productivity indices and the different women's empowerment measures. Before presenting the results of the determinants of productivity change and its components, we first discuss the results of the Wu-Hausman test of the exogeneity of the WEAI variables. The results of the exogeneity tests ${ }^{9}$ indicate that the null hypothesis of exogeneity of the WEAI variables cannot be rejected in all specifications. However as noted earlier and given the absence of better instruments in our database, the WEAI results will be interpreted as implying correlation rather than causation.

Columns 2-5 of Table 6 present the bootstrap regression estimates of the impact of women's empowerment (empowerment score based on Alkire et al. [10]) and other control variables on productivity change and its decompositions. The results show that except for scale efficiency change, the relationship between women's empowerment in agriculture and productivity change, efficiency change, and technical change is positive and statistically significant at 1\%, 10\%, and 5\% level, respectively. Columns 6-13 of Table 6 further reinforce this association; alternative specifications of women's empowerment scores are also statistically significant at $1 \%$ and $5 \%$ level, and positively related to the Bangladesh rice farming productivity change, efficiency change, and technical change.

The positive relationship between empowerment scores and productivity change indicates that a $1 \%$ increase in women's empowerment score increases farm productivity by $0.17 \%$ to $0.44 \%$. We can also imply that farm productivity can be increased by $3 \%$ to $22 \%$ if the primary female decision maker of the household achieves adequacy in at least $80 \%$ of the weighted indicators (threshold level empowerment). ${ }^{10}$ The results also indicate that empowering farm household women can move a farm household toward the best practice 
frontier. A $1 \%$ increase in empowerment score implies $0.17 \%$ to $0.46 \%$ increase in efficiency change or, alternatively, if the primary female decision maker achieves an adequacy score of 0.80 , the efficiency change index improves by $3 \%$ to $23 \%{ }^{11}$ This indicates that women's greater agency over WEAI domains has the potential to help farm households to increase the level of utilization of the potential (maximal capacity) of the production technology. Similarly, findings also indicate that empowering woman shifts farm's production frontier upward by $0.04 \%$ to $0.08 \%$. This implies that lifting primary female decision maker's empowerment score up to the threshold level of empowerment could improve the technical change index by $1 \%$ to $4 \% \cdot{ }^{12}$ This indicates that there is scope for the sample households to increase technological levels and innovative capabilities through ensuring farm household women's agency over domains of WEAI.

Table 6 (Columns 2-5) also shows that, among the household-level characteristics, sex, education, dependency ratio, household size, and income share from the nonagricultural enterprise have statistically significant effects on the productivity indices (for a detailed explanation of control variables see online supplement S2).

\section{Table 7. Results of the OLS bootstrap regression of the determinants of farm} productivity change and its components (Empowerment gap)

\begin{tabular}{llll}
\hline Dependent variable & $\begin{array}{l}\text { Model 1: } \\
\text { Empowerment } \\
\text { gap based on } \\
\text { Alkire et al. [10] }\end{array}$ & $\begin{array}{l}\text { Model 2: Alternative } \\
\text { empowerment gap } \\
\text { based on approach 1 }\end{array}$ & $\begin{array}{l}\text { Model 3: Alternative } \\
\text { empowerment gap } \\
\text { based on approach 2 }\end{array}$ \\
\hline Productivity change & $-0.128^{* *}$ & $-0.182^{*}$ & -0.117 \\
Efficiency change & $(0.063)$ & $(0.109)$ & $(0.077)$ \\
Technical change & -0.105 & -0.224 & -0.123 \\
& $(0.094)$ & $(0.157)$ & $(0.112)$ \\
Scale efficiency change & -0.027 & -0.016 & -0.013 \\
& $(0.018)$ & $(0.028)$ & $(0.021)$ \\
\hline Soure & 0.002 & -0.007 & -0.001 \\
\end{tabular}

Source: Authors' calculations

Note: Standard errors in parentheses; $* * *$, and *** indicate significance based on $90 \%, 95 \%$ and $99 \%$ bootstrap confidence level, respectively 
Table 7 reports the effect of empowerment gap on productivity indices, estimated using the approach detailed in section 3.2 (see online supplement $\mathrm{S} 3$ for the full set of results). The results (column 2) indicate that the empowerment gap is negatively associated with productivity change and this effect is statistically significant at the 5\% level. Empowerment gap calculated based on alternative approach 1 (column 3) also has a significant negative impact on productivity change, further reiterating the findings of column 2 . This implies that a $1 \%$ reduction in the gap between primary male and female decision maker's 5DE score is associated with an increase in farm household's overall productivity by $0.13 \%$ to $0.18 \%$. The results of the control variables (see online supplement S3) are similar to those reported in table 6 in terms of signs and significance, and the magnitudes of the coefficients are also quite similar. 
Table 8. Results of the OLS bootstrap regression of the determinants of farm productivity change and its components (WEAI domains)

\begin{tabular}{|c|c|c|c|c|}
\hline & $\begin{array}{l}\text { Productivity } \\
\text { change }\end{array}$ & $\begin{array}{l}\text { Efficiency } \\
\text { change }\end{array}$ & $\begin{array}{l}\text { Technical } \\
\text { change }\end{array}$ & $\begin{array}{l}\text { Scale } \\
\text { efficiency } \\
\text { change }\end{array}$ \\
\hline \multicolumn{5}{|c|}{ Model 1: Empowerment domain score based on Alkire et al. [10] } \\
\hline Empowerment score: Production & $\begin{array}{l}0.483 * * * \\
(0.168)\end{array}$ & $\begin{array}{l}0.458^{*} \\
(0.241)\end{array}$ & $\begin{array}{l}0.115 * * * \\
(0.041)\end{array}$ & $\begin{array}{l}0.038 \\
(0.090)\end{array}$ \\
\hline Empowerment score: Resource & $\begin{array}{l}0.064 \\
(0.179)\end{array}$ & $\begin{array}{l}0.091 \\
(0.265)\end{array}$ & $\begin{array}{l}0.041 \\
(0.042)\end{array}$ & $\begin{array}{l}-0.067 \\
(0.058)\end{array}$ \\
\hline Empowerment score: Income & $\begin{array}{l}-0.010 \\
(0.140)\end{array}$ & $\begin{array}{l}-0.075 \\
(0.211)\end{array}$ & $\begin{array}{l}-0.021 \\
(0.034)\end{array}$ & $\begin{array}{l}0.026 \\
(0.044)\end{array}$ \\
\hline Empowerment score: Leadership & $\begin{array}{l}0.096 \\
(0.205)\end{array}$ & $\begin{array}{l}0.224 \\
(0.275)\end{array}$ & $\begin{array}{l}0.033 \\
(0.053)\end{array}$ & $\begin{array}{l}-0.196^{*} \\
(0.103)\end{array}$ \\
\hline Empowerment score: Time & $\begin{array}{l}0.196 \\
(0.172)\end{array}$ & $\begin{array}{l}0.174 \\
(0.258)\end{array}$ & $\begin{array}{l}0.016 \\
(0.042)\end{array}$ & $\begin{array}{l}0.083 \\
(0.078)\end{array}$ \\
\hline \multicolumn{5}{|c|}{ Model 2: Alternative empowerment domain score based on approach 1} \\
\hline Empowerment score: Production & $\begin{array}{l}0.798 * * * \\
(0.233)\end{array}$ & $\begin{array}{l}0.885 * * * \\
(0.329)\end{array}$ & $\begin{array}{l}0.121 * * \\
(0.054)\end{array}$ & $\begin{array}{l}0.147 \\
(0.179)\end{array}$ \\
\hline Empowerment score: Resource & $\begin{array}{l}0.843 \\
(0.593)\end{array}$ & $\begin{array}{l}0.919 \\
(0.837)\end{array}$ & $\begin{array}{l}-0.080 \\
(0.142)\end{array}$ & $\begin{array}{l}0.677 \\
(0.542)\end{array}$ \\
\hline Empowerment score: Income & $\begin{array}{l}-0.091 \\
(0.413)\end{array}$ & $\begin{array}{l}-0.255 \\
(0.583)\end{array}$ & $\begin{array}{l}0.124 \\
(0.083)\end{array}$ & $\begin{array}{l}-0.311 \\
(0.247)\end{array}$ \\
\hline Empowerment score: Leadership & $\begin{array}{l}0.314 \\
(0.574)\end{array}$ & $\begin{array}{l}0.576 \\
(0.806)\end{array}$ & $\begin{array}{l}0.047 \\
(0.118)\end{array}$ & $\begin{array}{l}-0.472 \\
(0.348)\end{array}$ \\
\hline Empowerment score: Time & $\begin{array}{l}0.253 \\
(0.205)\end{array}$ & $\begin{array}{l}0.293 \\
(0.298)\end{array}$ & $\begin{array}{l}0.008 \\
(0.049)\end{array}$ & $\begin{array}{l}0.112 \\
(0.119)\end{array}$ \\
\hline \multicolumn{5}{|c|}{ Model 3: Alternative empowerment domain score based on approach 2} \\
\hline Empowerment score: Production & $\begin{array}{l}0.762 * * * \\
(0.217)\end{array}$ & $\begin{array}{l}0.838 * * * \\
(0.314)\end{array}$ & $\begin{array}{l}0.120 * * \\
(0.049)\end{array}$ & $\begin{array}{l}0.132 \\
(0.174)\end{array}$ \\
\hline Empowerment score: Resource & $\begin{array}{l}0.412 * * \\
(0.199)\end{array}$ & $\begin{array}{l}0.500 * \\
(0.303)\end{array}$ & $\begin{array}{l}0.047 \\
(0.049)\end{array}$ & $\begin{array}{l}0.014 \\
(0.084)\end{array}$ \\
\hline Empowerment score: Income & $\begin{array}{l}-0.101 \\
(0.239)\end{array}$ & $\begin{array}{l}-0.181 \\
(0.336)\end{array}$ & $\begin{array}{l}0.014 \\
(0.054)\end{array}$ & $\begin{array}{l}-0.132 \\
(0.124)\end{array}$ \\
\hline Empowerment score: Leadership & $\begin{array}{l}-0.087 \\
(0.249)\end{array}$ & $\begin{array}{l}0.092 \\
(0.330)\end{array}$ & $\begin{array}{l}-0.024 \\
(0.064)\end{array}$ & $\begin{array}{l}-0.217 \\
(0.133)\end{array}$ \\
\hline Empowerment score: Time & $\begin{array}{l}0.187 \\
(0.171)\end{array}$ & $\begin{array}{l}0.167 \\
(0.255)\end{array}$ & $\begin{array}{l}0.017 \\
(0.042)\end{array}$ & $\begin{array}{l}0.077 \\
(0.080)\end{array}$ \\
\hline
\end{tabular}

Source: Authors' calculations

Note: Standard errors in parentheses; * **, and *** indicate significance based on $90 \%, 95 \%$ and $99 \%$ bootstrap confidence level, respectively 
Table 8 reports the effect of WEAI domains on productivity indices (see supplement S3 for the full set of results). Results indicate that farm household women's agency over production domain is positively associated with productivity change, efficiency change, and technical change. Findings suggest that a 1\% increase in women's empowerment in production domain leads to a $0.48 \%$ to $0.80 \%$ increase in productivity of the sample farms. Results also indicate that a $1 \%$ increase in primary female decision makers empowerment in production domain leads to efficiency gains of between $0.46 \%$ and $0.89 \%$. Empowerment in the production domain is also positively associated with technical change as the results reveal that it can lead to technological gains of about $0.12 \%$ In the main model (Model 1), the rest of the WEAI domains were not found to have a statistically significant effect on productivity change and its components, except for the leadership domain which is weakly significant only in one out of the three models tested.

Table 9. Results of the OLS bootstrap regression of the determinants of farm productivity change and its components (production domain indicators)

\begin{tabular}{|c|c|c|c|c|}
\hline & $\begin{array}{l}\text { Productivity } \\
\text { change }\end{array}$ & $\begin{array}{l}\text { Efficiency } \\
\text { change }\end{array}$ & $\begin{array}{l}\text { Technical } \\
\text { change }\end{array}$ & $\begin{array}{l}\text { Scale } \\
\text { efficiency } \\
\text { change }\end{array}$ \\
\hline \multicolumn{5}{|c|}{ Model 1: Production domain indicator based on Alkire et al. [10] } \\
\hline Input in productive decisions & $\begin{array}{l}0.045 \\
(0.237)\end{array}$ & $\begin{array}{l}-0.220 \\
(0.351)\end{array}$ & $\begin{array}{l}0.087 \\
(0.064)\end{array}$ & $\begin{array}{l}-0.017 \\
(0.087)\end{array}$ \\
\hline Autonomy in production & $\begin{array}{l}0.944 * * * \\
(0.239)\end{array}$ & $\begin{array}{l}1.121 * * * \\
(0.338)\end{array}$ & $\begin{array}{l}0.133 * * \\
(0.056) \\
\end{array}$ & $\begin{array}{l}0.094 \\
(0.130) \\
\end{array}$ \\
\hline \multicolumn{5}{|c|}{ Model 2: Alternative production domain indicator based on approach 1} \\
\hline Input in productive decisions & $\begin{array}{l}0.564 \\
(0.712)\end{array}$ & $\begin{array}{l}-0.102 \\
(0.993)\end{array}$ & $\begin{array}{l}0.390 * * * \\
(0.144)\end{array}$ & $\begin{array}{l}0.040 \\
(0.308)\end{array}$ \\
\hline Autonomy in production & $\begin{array}{l}0.896 * * * \\
(0.240)\end{array}$ & $\begin{array}{l}1.101 * * * \\
(0.345)\end{array}$ & $\begin{array}{l}0.107^{*} \\
(0.057)\end{array}$ & $\begin{array}{l}0.088 \\
(0.120)\end{array}$ \\
\hline \multicolumn{5}{|c|}{ Model 3: Alternative production domain indicator based on approach 2} \\
\hline Input in productive decisions & $\begin{array}{l}0.175 \\
(0.484)\end{array}$ & $\begin{array}{l}-0.058 \\
(0.713)\end{array}$ & $\begin{array}{l}0.071 \\
(0.113)\end{array}$ & $\begin{array}{l}0.093 \\
(0.269)\end{array}$ \\
\hline Autonomy in production & $\begin{array}{l}0.945 * * * \\
(0.230)\end{array}$ & $\begin{array}{l}1.093 * * * \\
(0.333)\end{array}$ & $\begin{array}{l}0.143 * * \\
(0.056) \\
\end{array}$ & $\begin{array}{l}0.089 \\
(0.129) \\
\end{array}$ \\
\hline
\end{tabular}

Note: Standard errors in parentheses; * **, and *** indicate significance based on 90\%, $95 \%$ and $99 \%$ bootstrap confidence level, respectively 
We also estimate the effect of indicators of production domain on productivity indices. Results indicate that autonomy in production is statistically significant in all three models and positively associated with productivity change, efficiency change, and technical change (Table 9, also see online supplement S3 for the full set of results). This implies that improvements in primary female decision marker's ability to make independent choices regarding agricultural production increases farm household's overall productivity through efficiency and technological gains. Input in production decisions, however, is statistically significant in alternative model (Model 2), and positively associated with only technical change.

\section{Conclusions and discussion}

This study contributes to the existing literature with an assessment of the association between women's empowerment in agriculture and farm household productivity change and its components. This assessment involves two steps. First, a nonparametric Malmquist approach is used to estimate household-specific productivity change and its decomposition. Next, we employ a non-parametric bootstrap OLS regression method to analyze the link between women's empowerment in agriculture (and a set of control variables) and productivity change and its decomposition. To better understand the relationship between women's empowerment and productivity change, we also analyze the effect of gender parity gap, individual domains and indicators of women's empowerment, and the same measures derived using two alternative scoring procedures. The empirical application focuses on Bangladesh rice farms.

Our first-stage results show that over the sample period, farm household productivity decreased by an average of $24 \%$. The main driver of productivity decline was 
technological regress estimated at 35\%. Despite the observed negative technical change, we find that the sample households, on average, used the existing production technology more efficiently over time as we record a $15 \%$ improvement in efficiency change during the estimation period. In addition, these households achieved adjustments in production scale that allowed them to obtain a 3\% growth in productivity over time. Our second stage results indicate that empowering women in agriculture, specifically improving primary female decision makers ability to make independent choices regarding agricultural production, is positively and significantly associated with productivity change, efficiency change, and technical change, while it is not significantly associated with scale efficiency change. We further found that closing the gender parity gap is associated with higher farm productivity. These results hold for alternative measures of empowerment that we test, which validate the inference that might be drawn from this study. We also find that apart from women's empowerment in agriculture, climatic variables, and household characteristics, such as sex, education, household size and location, explain differences in productivity change and its components among households in this study.

Besides the intrinsic value of empowering women involved in farming, our main finding, that women's empowerment in agriculture is associated with higher farm productivity, is even more compelling in view of the fact that population growth, land scarcity, and other resource constraints challenge agricultural regulators and farmers to find innovative ways to use existing farm resources more efficiently. In the case of Bangladesh, women's empowerment in agriculture might not only be valued for contributing towards development goals, but also as a means for increasing agricultural productivity. 
Farm household women's contribution to agriculture in Bangladesh are traditionally confined to homestead production (farming carried out around homestead) and post-harvest activities such as drying, sorting, packaging of crops [62,63]. Since the interaction pathway between empowerment and productivity is entirely through the production domain, interventions that increase the primary female decision makers relative autonomy in agricultural productive decisions might help the country boost its agricultural productivity.

This research on the relationship between women's empowerment in agriculture and farm productivity growth focuses on a single developing country. Future research could extend the work in different ways, such as by examining whether similar findings would be observed in different developing countries where cultural and legal (e.g., women's rights) differences can affect women's involvement in agricultural decisionmaking, different time periods or types of farms, and the role of actual policies to improve women's empowerment where relevant data are available. If sufficient data were available, then the association of women's empowerment and productivity might be decomposed by growing seasons, crop varieties, production technology heterogeneity, market orientation, or at the scale of field or plot. Exploration into these areas could develop further the empirical association of women's empowerment and rice farming household productivity change in Bangladesh. 


\section{References}

1. World Bank, Food and Agriculture Organization, International Fund for Agricultural Development. Gender in Agriculture Sourcebook [Internet]. Washington, DC: World Bank; 2009. Available from: http://elibrary.worldbank.org/doi/book/10.1596/978-08213-7587-7

2. Ivleva D, Alexander Müller, Pohl B. Beware the Politics: Leveraging foreign policy for SDG implementation. Berlin, Germany: adelphi; 2019.

3. Rizov M, Pokrivcak J, Ciaian P. CAP Subsidies and Productivity of the EU Farms. J Agric Econ. 2013;64(3):537-57.

4. Mary S. Assessing the Impacts of Pillar 1 and 2 Subsidies on TFP in French Crop Farms. J Agric Econ. 2013;64(1):133-44.

5. Skevas T, Lansink AO. Reducing Pesticide Use and Pesticide Impact by Productivity Growth: the Case of Dutch Arable Farming. J Agric Econ. 2014;65(1):191-211.

6. Food and Agriculture Organization. Women in agriculture: closing the gender gap for development. Rome, Italy; 2011. 147 p. (The state of food and agriculture).

7. Bozoğlu M, Ceyhan V. Measuring the technical efficiency and exploring the inefficiency determinants of vegetable farms in Samsun province, Turkey. Agric Syst. 2007 Jun 1;94(3):649-56.

8. Seymour G. Women's empowerment in agriculture: Implications for technical efficiency in rural Bangladesh. Agric Econ. 2017;48(4):513-22.

9. Coelli TJ, Rao DSP, O’Donnell CJ, Battese GE. An Introduction to Efficiency and Productivity Analysis [Internet]. 2nd ed. Springer US; 2005. Available from: https://www.springer.com/gp/book/9780387242651

10. Alkire S, Meinzen-Dick R, Peterman A, Quisumbing A, Seymour G, Vaz A. The Women's Empowerment in Agriculture Index. World Dev. 2013 Dec 1;52:71-91.

11. Diiro GM, Seymour G, Kassie M, Muricho G, Muriithi BW. Women's empowerment in agriculture and agricultural productivity: Evidence from rural maize farmer households in western Kenya. PLOS ONE. 2018 May 31;13(5):e0197995.

12. Wouterse F. The Role of Empowerment in Agricultural Production: Evidence from Rural Households in Niger. J Dev Stud. 2019 Apr 3;55(4):565-80.

13. Foreign Agricultural Service. Bangladesh Grain and Feed Annual 2019. Dhaka, Bangladesh: United States Department of Agriculture-; 2019 p. 29. (Global agricultural information network). Report No.: BG 1903. 
14. Sayeed KA, Yunus MM. Rice prices and growth, and poverty reduction in Bangladesh [Internet]. Rome, Italy: Food and Agriculture Organization (FAO); 2018. Available from: http://www.fao.org/documents/card/en/c/I8332EN/

15. Gollin D, Parente S, Rogerson R. The Role of Agriculture in Development. Am Econ Rev. 2002 May;92(2):160-4.

16. O'Donnell CJ. Measuring and decomposing agricultural productivity and profitability change. Aust J Agric Resour Econ. 2010;54(4):527-60.

17. Christiaensen L, Demery L, Kuhl J. The (evolving) role of agriculture in poverty reduction-An empirical perspective. J Dev Econ. 2011 Nov 1;96(2):239-54.

18. Ligon E, Sadoulet E. Estimating the Relative Benefits of Agricultural Growth on the Distribution of Expenditures. World Dev. 2018 Sep 1;109:417-28.

19. Rahman S, Salim R. Six Decades of Total Factor Productivity Change and Sources of Growth in Bangladesh Agriculture (1948-2008). J Agric Econ. 2013;64(2):27594.

20. Hossain MK, Kamil AA, Baten MA, Mustafa A. Stochastic Frontier Approach and Data Envelopment Analysis to Total Factor Productivity and Efficiency Measurement of Bangladeshi Rice. PLOS ONE. 2012 Oct 15;7(10):e46081.

21. Coelli T, Rahman S, Thirtle C. A stochastic frontier approach to total factor productivity measurement in Bangladesh crop agriculture, 1961-92. J Int Dev. 2003;15(3):321-33.

22. Wadud MdA. Technical, Allocative, and Economic Efficiency of Farms in Bangladesh: A Stochastic Frontier and DEA Approach. J Dev Areas. 2003;37(1):109-26.

23. Wadud A, White B. Farm household efficiency in Bangladesh: a comparison of stochastic frontier and DEA methods. Appl Econ. 2000 Oct 1;32(13):1665-73.

24. Coelli T, Rahman S, Thirtle C. Technical, Allocative, Cost and Scale Efficiencies in Bangladesh Rice Cultivation: A Non-parametric Approach. J Agric Econ. 2002;53(3):607-26.

25. Theodoridis AM, Anwar MdM. A comparison of DEA and SFA methods: a case study of farm households in Bangladesh. J Dev Areas. 2011;45(1):95-110.

26. MEHRA R. Women, Empowerment, and Economic Development. Ann Am Acad Pol Soc Sci. 1997 Nov 1;554(1):136-49. 
27. Kabeer N. Resources, Agency, Achievements: Reflections on the Measurement of Women's Empowerment. Dev Change. 1999;30(3):435-64.

28. Mosedale S. Assessing women's empowerment: towards a conceptual framework. J Int Dev. 2005;17(2):243-57.

29. Batliwala S. Taking the Power out of Empowerment: An Experiential Account. Dev Pract. 2007;17(4/5):557-65.

30. Malhotra A, Schuler SR. Women's empowerment as a variable in international development. In: Deepa Narayan, editor. Measuring empowerment: cross disciplinary perspectives [Internet]. Washington, DC: World Bank; 2005. p. 71-88. Available from: https://documents.worldbank.org/en/publication/documentsreports/documentdetail/960161468175149824/Measuring-empowerment-crossdisciplinary-perspectives

31. Ranis G, Stewart F, Ramirez A. Economic Growth and Human Development. World Dev. 2000 Feb 1;28(2):197-219.

32. Duflo E, Udry C. Intrahousehold Resource Allocation in Cote d'Ivoire: Social Norms, Separate Accounts and Consumption Choices [Internet]. Cambridge, MA: National Bureau of Economic Research; 2004 May. p. w10498. Report No.: w10498. Available from: http://www.nber.org/papers/w10498.pdf

33. Duflo E. Women Empowerment and Economic Development. J Econ Lit. 2012 Dec;50(4):1051-79.

34. Sraboni E, Malapit HJ, Quisumbing AR, Ahmed AU. Women's Empowerment in Agriculture: What Role for Food Security in Bangladesh? World Dev. 2014 Sep $1 ; 61: 11-52$.

35. Malapit HJL, Kadiyala S, Quisumbing AR, Cunningham K, Tyagi P. Women's Empowerment Mitigates the Negative Effects of Low Production Diversity on Maternal and Child Nutrition in Nepal. J Dev Stud. 2015 Aug 3;51(8):1097-123.

36. Cunningham K, Ploubidis GB, Menon P, Ruel M, Kadiyala S, Uauy R, et al. Women's empowerment in agriculture and child nutritional status in rural Nepal. Public Health Nutr. 2015 Dec;18(17):3134-45.

37. Malapit HJL, Quisumbing AR. What dimensions of women's empowerment in agriculture matter for nutrition in Ghana? Food Policy. 2015 Apr 1;52:54-63.

38. Alderman H, Chiappori P-A, Haddad L, Hoddinott J, Kanbur R. Unitary versus Collective Models of the Household: Is It Time to Shift the Burden of Proof? World Bank Res Obs. 1995;10(1):1-19. 
39. Browning M, Chiappori PA. Efficient Intra-Household Allocations: A General Characterization and Empirical Tests. Econometrica. 1998;66(6):1241-78.

40. Agarwal B. "Bargaining" and Gender Relations: Within and Beyond the Household. Fem Econ. 1997 Jan 1;3(1):1-51.

41. Hazarika G, Guha-Khasnobis B. Women's Access to Microcredit and Children's Food Security in Rural Malawi. J Afr Dev. 2012;14(1):27-46.

42. Pitt MM, Khandker SR. The impact of Group-Based Credit Programs on Poor Households in Bangladesh: Does the Gender of Participants Matter? J Polit Econ. 1998;106(5):958-96.

43. Pitt MM, Khandker SR, Chowdhury OH, Millimet DL. Credit programs for the poor and the health status of children in rural bangladesh. Int Econ Rev. 2003;44(1):87118.

44. Rahman S. Whether crop diversification is a desired strategy for agricultural growth in Bangladesh? Food Policy. 2009 Aug 1;34(4):340-9.

45. Rahman S. Women's Labour Contribution to Productivity and Efficiency in Agriculture: Empirical Evidence From Bangladesh. J Agric Econ. 2010;61(2):31842.

46. Ronald William Shephard. Theory of Cost and Production Functions [Internet]. Princeton, NJ: Princeton University Press; 1970 [cited 2021 Jun 6]. Available from: https://press.princeton.edu/books/hardcover/9780691647524/theory-of-cost-andproduction-functions

47. Färe R, Grosskopf S, Lindgren B, Roos P. Productivity changes in Swedish pharamacies 1980-1989: A non-parametric Malmquist approach. J Product Anal. 1992 Jun 1;3(1):85-101.

48. Ray SC, Desli E. Productivity Growth, Technical Progress, and Efficiency Change in Industrialized Countries: Comment. Am Econ Rev. 1997;87(5):1033-9.

49. Førsund FR. On the calculation of the scale elasticity in DEA models. J Product Anal. 1996 Jul 1;7(2):283-302.

50. Odeck J. Statistical precision of DEA and Malmquist indices: A bootstrap application to Norwegian grain producers. Omega. 2009 Oct 1;37(5):1007-17.

51. Kapelko M, Lansink AO, Stefanou SE. Investment Age and Dynamic Productivity Growth in the Spanish Food Processing Industry. Am J Agric Econ. 2016;98(3):94661. 
52. William H. Greene. Econometric Analysis [Internet]. Upper Saddle River, NJ: Pearson Prentice Hall; 2008. Available from: /content/one-dot-com/one-dotcom/us/en/higher-education/product.html

53. Ahmed AU. Description of the Bangladesh integrated household survey [Internet]. Dhaka, Bangladesh: International Food Policy Research Institute (IFPRI); 2016. Available from: https://ebrary.ifpri.org/digital/collection/p15738coll3/id/493

54. Bangladesh Bureau of Statistics (BBS). Consumer Price Index (CPI), Inflation Rate and Wage Rate Index (WRI) in Bangladesh. Dhaka, Bangladesh: Ministry of Planning, Government of Bangladesh; 2016.

55. Alkire S, Malapit H, Meinzen-Dick R, Peterman A, Quisumbing A, Seymour G, et al. Instructional Guide on the Women's Empowerment in Agriculture Index. Washington, DC: International Food Policy Research Institute (IFPRI); 2013 p. 82.

56. Bangladesh Bureau of Statistics (BBS). Yearbook of agricultural statistics-2014. Dhaka, Bangladesh: Ministry of Planning, Government of Bangladesh;

57. Briec W, Kerstens K. Infeasibility and Directional Distance Functions with Application to the Determinateness of the Luenberger Productivity Indicator. J Optim Theory Appl. 2009 Jan 7;141(1):55.

58. Färe R, Grosskopf S, Norris M, Zhang Z. Productivity Growth, Technical Progress, and Efficiency Change in Industrialized Countries. Am Econ Rev. 1994;84(1):66-83.

59. Biswas JK, Naher UA. Soil nutrient stress and rice production in Bangladesh. In: Mirza Hasanuzzaman, Masayuku Fujita, Kamrun Nahar, Jiban Biswas, editors. Advances in Rice Research for Abiotic Stress Tolerance [Internet]. Cambridge, MA: Woodhead Publishing; 2019. p. 431-46. Available from: https://www.elsevier.com/books/advances-in-rice-research-for-abiotic-stresstolerance/hasanuzzaman/978-0-12-814332-2

60. FGR. Fertilizer recommendation guide. Dhaka, Bangladesh: Bangladesh Agricultural Research Council; 2012.

61. Hossain MdZ. Farmer's view on soil organic matter depletion and its management in Bangladesh. Nutr Cycl Agroecosystems. 2001 Sep 1;61(1):197-204.

62. Jaim WMH, Hossain M. Women's Participation in Agriculture in Bangladesh: Trends, Determinants and Impact on Livelihoods [Internet]. 2011 ASAE 7th International Conference, October 13-15, Hanoi, Vietnam. Asian Society of Agricultural Economists (ASAE); 2011 Oct. (2011 ASAE 7th International Conference, October 13-15, Hanoi, Vietnam). Report No.: 290424. Available from: https://ideas.repec.org/p/ags/asae11/290424.html 
63. Akter S, Krupnik TJ, Rossi F, Khanam F. The influence of gender and product design on farmers' preferences for weather-indexed crop insurance. Glob Environ Change. 2016 May 1;38:217-29. 


\section{End Notes}

${ }^{i}$ Although Bozoğlu and Ceyhan [7] do not explicitly use the term "women's empowerment", their measure of women's participation in farm decision-making can be considered a measure of women's empowerment.

ii Technical efficiency is defined as the ability of a decision making unit to produce an output using the lowest possible amount of inputs (input oriented technical efficiency), or to achieve the maximum potential output from a given set of inputs (output oriented technical efficiency) [9].

iii First round (2011/12) and second round (2015/2016) collect data for crop cultivated during December 2010 to November 2011 and December 2013 to November 2014, respectively.

iv There are 33 households in the dataset that have split between rounds. For comparison purpose, we only considered the original household (parent household) in such cases.

${ }^{v}$ On average, in both rounds five cultivable/arable plots are available to sample farmers.

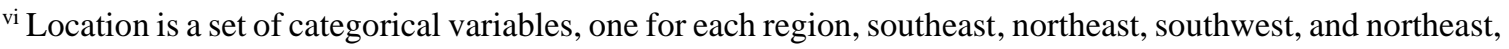
with the southeast dummy variable excluded from the regression analysis to avoid perfect collinearity.

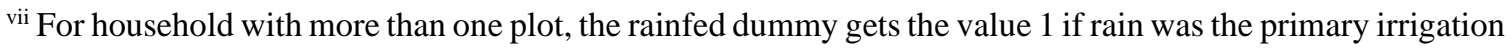
source in the majority of the plots. A similar rule applies for the tenancy status variable. This variable takes the value 1 if the majority of a household's plots were operated under cash lease or crop-sharing arrangement.

viii We also defined rainfed variable as the ratio of rainfed plots to total plots available to a household. Similarly, for tenancy variable, we estimated the ratio of plots taken-in through a cash lease or crop-sharing arrangement to total plots. We find no significant difference in estimating the empowerment-productivity change relationship when we replace the categorical variables with continuous measures of rainfed and tenancy.

${ }^{9}$ The results of the exogeneity tests are available from the authors upon request.

${ }^{10}$ Calculated as the estimated parameter times the average gap between the $80 \%$ index threshold required to be considered empowered and the average empowerment score, or (estimate* $(80 \%$ of the weighted indicators-mean empowerment scores)) $* 100$.

${ }^{11}$ See endnote 10.

${ }^{12}$ See endnote 10. 


\section{Supplement S1}

\section{Alternative approach 1}

The original WEAI has an adequacy requirement for each indicator. For example, for a woman to be empowered under resources domain, it is adequate for her (i) to own any assets provided that it is not just one small asset (a chicken, nonmechanized equipment or small consumer durables), (ii) to participate in at least one type of decision to buy, sell or transfer a major asset that a household owns and (iii) to contribute to at least one decision regarding credit access and use. We modified these assumptions to develop empowerment scores based on the gradations of women's power rather than binary assessments. For example, in the resource domain of the first alternative, we assumed that the more assets a woman owns, the higher the empowerment score, and consequently, we record a higher indicator relating to ownership of assets. Similarly, a woman scores higher under the resource domain if she participates in more decisions regarding purchase, sale, or transfer of assets with more significant input compared to a woman who participates in the decision-making process with low input or does not participate at all. The same assumption is employed for access to and decisions about credit: the more access she has and the higher input she provides in decision making regarding sources of credit and credit proceeds utilization, the higher the empowerment score in this indicator.

\section{Alternative approach 2}

The second alternative approach focuses on a woman's engagement and relative input in the activity or decision-making process in which a household participates. For example, under the input in productive decision indicator, a woman is asked about her input in productive decisions around activities such as food crop farming, cash farming, livestock 
raising, non-farm economic activities, wage and salary employment, and fishing or fish culture. The answer scale ranges from $1=$ "no input" to $5=$ "input in all decisions." Under the assumptions of original WEAI, a woman is deemed as empowered if she participates in at least two activities in which she has at least "some input." The fundamental idea behind the second alternative approach is recognizing that a woman might belong to a household that is engaged in only a specific activity, such as cash crop farming. Alternatively, the household might be engaged in all the activities, but the primary female decision-maker has a varying degree of engagement in those activities. Our idea is to develop a scoring system that does not reduce the empowerment of a woman for not contributing to an activity where a household does not participate and not to exaggerate the empowerment a woman who contributes some input in decision making in a minority of several household pursuits compared to a woman who provides more input into a range of agricultural production decisions.

Assumptions of original WEAI, first and second alternative approach are discussed in detail in Table 1. 
Supplement S1 Table 1. Empowerment assumptions

\begin{tabular}{|c|c|c|c|c|c|c|}
\hline Domains|Index & Indicator & Weight & Survey question & WEAI & Alternative approach 1 & Alternative approach 2 \\
\hline \multirow[t]{2}{*}{$\begin{array}{l}\text { Agricultural } \\
\text { Production }\end{array}$} & $\begin{array}{l}\text { Input in } \\
\text { productive } \\
\text { decisions }\end{array}$ & 0.10 & $\begin{array}{l}\text { How much input did you have in making } \\
\text { decisions about food crop farming, cash crop } \\
\text { farming, livestock raising, and fish culture? } \\
\text { To what extent do you feel you can make your } \\
\text { own personal decisions regarding these } \\
\text { aspects of household life if you want(ed) to: } \\
\text { agriculture production, which inputs to buy, } \\
\text { which types of crops to grow for agricultural } \\
\text { production, when to take or who should take } \\
\text { crops to market, and livestock raising? }\end{array}$ & $\begin{array}{l}\text { Achievement in two activities. } \\
\text { Inadequate if the individual } \\
\text { participates but does not/has not at } \\
\text { least some input in decisions or } \\
\text { does not make decisions nor feels } \\
\text { he or she could. }\end{array}$ & $\begin{array}{l}\text { No minimum requirement of } \\
\text { activities. Both actual inputs } \\
\text { and intent are considered. } \\
\text { Inputs and extent account for } \\
60 \% \text { and } 40 \% \text { of the weight, } \\
\text { respectively. Weights are } \\
\text { assigned based on the answer } \\
\text { scale. Adequacy is calculated } \\
\text { as the weighted average of } \\
\text { every activity and intent. }\end{array}$ & $\begin{array}{l}\text { No minimum requirement } \\
\text { of activities. Considers only } \\
\text { those activities or intents in } \\
\text { which responses have been } \\
\text { recorded. } \\
\text { The score is calculated as } \\
\text { the weighted average of the } \\
\text { degree of the inputs OR } \\
\text { intent (cut off is small } \\
\text { extent) of activities, } \\
\text { whichever is greater. }\end{array}$ \\
\hline & $\begin{array}{l}\text { Autonomy in } \\
\text { production }\end{array}$ & 0.10 & $\begin{array}{l}\text { My actions in [domain] are partly because I } \\
\text { will get in trouble with someone if I act } \\
\text { differently. Regarding [domain] I do what I do } \\
\text { so others don't think poorly of me. Regarding } \\
\text { [domain] I do what I do because I personally } \\
\text { think it is the right thing to do. Agricultural } \\
\text { production, inputs to buy, crops to grow, take } \\
\text { to market, livestock. }\end{array}$ & $\begin{array}{l}\text { Achievement in any. Inadequate if } \\
\text { Relative Autonomy Indicator } \\
\text { (RAI) is less than } 1 .\end{array}$ & $\begin{array}{l}\text { Achievement in any. } \\
\text { Inadequate if RAI is less than } \\
1 .\end{array}$ & $\begin{array}{l}\text { Achievement in any. } \\
\text { Inadequate if RAI is less } \\
\text { than } 1 .\end{array}$ \\
\hline \multirow[t]{3}{*}{$\begin{array}{l}\text { Access to and } \\
\text { Control of } \\
\text { Productive } \\
\text { Resources }\end{array}$} & $\begin{array}{l}\text { Asset } \\
\text { ownership }\end{array}$ & 0.07 & $\begin{array}{l}\text { Who would you say can use the [item] most of } \\
\text { the time? Agricultural land, large livestock, } \\
\text { small livestock, chickens and so on; } \\
\text { fishpond/equipment; farm equipment } \\
\text { (nonmechanized); farm equipment } \\
\text { (mechanized); nonfarm business equipment, } \\
\text { house; large durables; small durables; cell } \\
\text { phone; nonagricultural land (any); transport. }\end{array}$ & $\begin{array}{l}\text { Achievement in any if not only } \\
\text { one small asset (chickens, } \\
\text { nonmechanized equipment and } \\
\text { no small consumer durables). } \\
\text { Inadequate if the household does } \\
\text { not own any asset or if the } \\
\text { household owns the type of asset } \\
\text { but she or } \\
\text { he does not own most of it alone. }\end{array}$ & $\begin{array}{l}\text { Adequacy is calculated as the } \\
\text { weighted average of ALL large } \\
\text { and small assets owned by self } \\
\text { or jointly. }\end{array}$ & $\begin{array}{l}\text { No adequacy requirement. } \\
\text { The score is calculated as } \\
\text { the weighted average of the } \\
\text { assets owned by self or } \\
\text { jointly; large assets get } \\
\text { twice the weight of small } \\
\text { assets. }\end{array}$ \\
\hline & $\begin{array}{l}\text { Decisions } \\
\text { regarding the } \\
\text { purchase, sale, } \\
\text { or transfer of } \\
\text { land and assets }\end{array}$ & 0.07 & $\begin{array}{l}\text { Who would you say can decide whether to } \\
\text { sell, give away, rent/mortgage [item] most of } \\
\text { the time? Who contributes most to decisions } \\
\text { regarding a new purchase of [item]? } \\
\text { Agricultural land, large livestock, small } \\
\text { livestock, chickens and so on, fishpond, farm } \\
\text { equipment (nonmechanized), farm equipment } \\
\text { (mechanized). }\end{array}$ & $\begin{array}{l}\text { Achievement in any if not only } \\
\text { chickens and nonmechanized } \\
\text { farming equipment. Inadequate if a } \\
\text { household does not own any asset } \\
\text { or household owns the type of asset } \\
\text { but he or she does not participate in } \\
\text { decisions (exchange or buy) about } \\
\text { it. }\end{array}$ & $\begin{array}{l}\text { Adequacy is calculated as the } \\
\text { weighted average of ALL the } \\
\text { decisions associated with ALL } \\
\text { the assets owned by self or } \\
\text { jointly. }\end{array}$ & $\begin{array}{l}\text { Adequacy is calculated as } \\
\text { the weighted average of the } \\
\text { decisions associated with } \\
\text { large and small assets } \\
\text { owned by self or jointly; } \\
80 \% \text { of the weight is } \\
\text { assigned to large assets and } \\
\text { participating in at least one } \\
\text { decision regarding large } \\
\text { asset is required. }\end{array}$ \\
\hline & $\begin{array}{l}\text { Access to and } \\
\text { decisions } \\
\text { about credit }\end{array}$ & 0.07 & $\begin{array}{l}\text { Who made the decision to borrow/what to do } \\
\text { with money/item borrowed from [source]? } \\
\text { Nongovernmental } \\
\text { organization, informal lender, formal lender } \\
\text { (bank), friends or relatives, rotating savings } \\
\text { and credit associations (savings/credit group). }\end{array}$ & $\begin{array}{l}\text { Achievement in any. Inadequate if } \\
\text { the household has no credit or used } \\
\text { a source of credit but she or he did } \\
\text { not participate in any decisions } \\
\text { about it. }\end{array}$ & $\begin{array}{l}\text { Adequacy is calculated as the } \\
\text { weighted average of all the } \\
\text { decisions (to borrow and use) } \\
\text { regarding all the sources of } \\
\text { credit. }\end{array}$ & $\begin{array}{l}\text { At least one source of credit } \\
\text { is required. Adequacy is } \\
\text { calculated as the weighted } \\
\text { average of all the decisions } \\
\text { regarding a source in which } \\
\text { she participated. }\end{array}$ \\
\hline
\end{tabular}




\begin{tabular}{|c|c|c|c|c|c|c|}
\hline Domains\Index & Indicator & Weight & Survey question & WEAI & Alternative approach 1 & Alternative approach 2 \\
\hline Income & $\begin{array}{l}\text { Control over } \\
\text { use of income }\end{array}$ & 0.20 & $\begin{array}{l}\text { How much input did you have in decisions } \\
\text { about the use of income generated from food } \\
\text { crop, cash crop, livestock, nonfarm activities, } \\
\text { wages and salary, and fish culture? To what } \\
\text { extent do you feel you can make your own } \\
\text { personal decisions regarding these aspects of } \\
\text { household life if you want(ed) to: your own } \\
\text { wage or salary employment? Minor household } \\
\text { expenditures? }\end{array}$ & $\begin{array}{l}\text { Achievement in any if not only } \\
\text { minor household expenditures. } \\
\text { Inadequate if the individual } \\
\text { participates in the activity but has } \\
\text { no input or little input in decisions } \\
\text { about the income generated. }\end{array}$ & $\begin{array}{l}\text { Adequacy is calculated as the } \\
\text { weighted average of the degree } \\
\text { of inputs and the extent the } \\
\text { respondent feels she can make } \\
\text { decisions. Inputs and extent } \\
\text { account for } 90 \% \text { and } 10 \% \text { of } \\
\text { the weight respectively. }\end{array}$ & $\begin{array}{l}\text { Adequacy is calculated as } \\
\text { the weighted average of the } \\
\text { degree of inputs or extent } \\
\text { the respondent feels she can } \\
\text { make decisions, whichever } \\
\text { is greater. Input in only } \\
\text { minor household } \\
\text { expenditures is not enough. }\end{array}$ \\
\hline \multirow[t]{2}{*}{ Leadership } & $\begin{array}{l}\text { Group } \\
\text { membership }\end{array}$ & 0.10 & $\begin{array}{l}\text { Are you a member of any } \\
\text { agricultural/livestock/fisheries } \\
\text { producer/market group; water, forest users', } \\
\text { credit, or microfinance group; mutual help or } \\
\text { insurance group (including burial societies); } \\
\text { trade and business association; } \\
\text { civic/charitable group; local government; } \\
\text { religious group; other women's group; other } \\
\text { group? }\end{array}$ & $\begin{array}{l}\text { Achievement in any. Inadequate if } \\
\text { not part of at least one group. }\end{array}$ & $\begin{array}{l}\text { Adequacy is calculated as the } \\
\text { weighted average of ALL THE } \\
\text { MEMBERSHIP OPTIONS } \\
\text { (active/inactive) in all eleven } \\
\text { groups. }\end{array}$ & $\begin{array}{l}\text { Achievement in any. } \\
\text { Inadequate if not part of at } \\
\text { least one group. }\end{array}$ \\
\hline & $\begin{array}{l}\text { Speaking in } \\
\text { public }\end{array}$ & 0.10 & $\begin{array}{l}\text { Do you feel comfortable speaking up in public } \\
\text { to help decide on infrastructure (like small } \\
\text { wells, roads) to be built, to ensure proper } \\
\text { payment of wages for public work or other } \\
\text { similar programs, or to protest the } \\
\text { misbehavior of authorities or elected officials? }\end{array}$ & $\begin{array}{l}\text { Achievement in any. Inadequate if } \\
\text { not comfortable speaking in public. }\end{array}$ & $\begin{array}{l}\text { Adequacy is calculated as the } \\
\text { weighted average of the levels } \\
\text { of comfort associated with all } \\
\text { three public speaking contexts. }\end{array}$ & $\begin{array}{l}\text { Adequacy is calculated as } \\
\text { the weighted average of the } \\
\text { levels of comfort associated } \\
\text { with the context in which } \\
\text { she participates. }\end{array}$ \\
\hline \multirow[t]{2}{*}{ Time } & Workload & 0.10 & $\begin{array}{l}\text { Worked more than } 10.5 \text { hours in the previous } \\
24 \text { hours. }\end{array}$ & $\begin{array}{l}\text { Inadequate if individual works } \\
\text { more than } 10.5 \text { hours per day. }\end{array}$ & $\begin{array}{l}\text { Inadequate if individual works } \\
\text { more than } 10.5 \text { hours per day. }\end{array}$ & $\begin{array}{l}\text { Inadequate if individual } \\
\text { works more than } 10.5 \text { hours } \\
\text { per day. }\end{array}$ \\
\hline & Leisure & 0.10 & $\begin{array}{l}\text { How would you rate your satisfaction with } \\
\text { your time available for leisure activities such } \\
\text { as visiting neighbors, watching TV, listening } \\
\text { to the radio, seeing movies, or doing sports? }\end{array}$ & $\begin{array}{l}\text { Inadequate if not } \\
\text { satisfied }(<5) ; 5 \text { being neither } \\
\text { satisfied not dissatisfied. }\end{array}$ & $\begin{array}{l}\text { Adequacy is calculated as the } \\
\text { weighted average of the levels } \\
\text { of satisfaction. }\end{array}$ & $\begin{array}{l}\text { Inadequate if not } \\
\text { satisfied }(<5) ; 5 \text { being } \\
\text { neither satisfied not } \\
\text { dissatisfied. }\end{array}$ \\
\hline
\end{tabular}

Source: Alkire et al. [1] \& authors 


\section{Supplement S2}

This section discusses the control variable results of table 6 of the main text. Sex of the primary decision maker is negatively associated with technical change indicating female-headed households make, on average, less technological investments in their farm operations than male headed households. This could be due to the fact that women have relatively poor access to productive resources, inputs and services [2,3]. Education positively affects both the technical change and scale change index. A reason could be that education reduces barriers to adoption and implementation of new agricultural technologies that can not only help farm households to shift their production frontier upward but also bring them closer to the optimal scale. Results also indicate that the dependency ratio negatively affects productivity change and efficiency change. One possible explanation is that a higher dependency ratio replaces unpaid family labor with paid hired labor, which essentially lowers farms' economic performance as overall production cost rises due to reduced economics of scale. Household size is negatively associated with efficiency change and scale change implying that with the increase in the size of the household, a household's ability to use inputs more efficiently and expand the scale of the farm operations diminishes. It might be the case that households with more people spend more resources for their increased consumption needs and save less, limiting their ability to increase productivity at intensive (yield growth through efficient input mix) and extensive (production growth through land expansion) margins. On the other hand, an increase in the share of household income from non-agricultural sources induces a positive shift in efficiency change. This may be due to the fact that an increase in off-farm income increases a household's liquidity or access to credit, facilitating farm investment, including 
in better inputs (e.g., purchasing quality seeds, fertilizer), which helps farms to use better technology. The coefficient on irrigation (rainfed) does not have a statistically significant effect. This result differs from expectations based on at least some past studies [4,5], although comparisons are complicated because some past studies focus on a different measure of productivity such as yield. Moving to the tenancy variables, we found a statistically significant, positive effect on productivity change and technical change index. Results indicate that overall productivity increases when the plot(s) is taken-in through a cash lease or crop-sharing arrangement. The positive relationship between tenancy and technical change implies that technological improvement differs depending on the operational status of the arable land. On average, technological improvement is higher in the lands operated under cash lease or crop-sharing arrangement compared to the lands operated under different tenure systems such as owner-operated, group leasing, or joint operation. Both weather variables have a statistically significant impact on productivity indices. The rainfall change variable negatively affects the productivity change and technical change index, but the effect is positive for scale efficiency change. The temperature change variable has a positive effect on productivity, efficiency, and technical change index. Among the locational dummies, households located in northwestern, northeastern, and southwestern districts were found to exhibit technological progress and regress, respectively, compared to households located in the southeastern districts of the country. Households situated in the northeastern districts were also found to experience productivity growth and efficiency gains compared to those in the southeastern districts of the country. 


\section{Supplement S3}

Supplement S3 Table 1. Results of the OLS bootstrap regression of the determinants of farm productivity change and its components

(Empowerment gap)

\begin{tabular}{|c|c|c|c|c|c|c|c|c|c|c|c|c|}
\hline \multirow{2}{*}{ Variables } & \multicolumn{4}{|c|}{ Model 1: Empowerment gap based on Alkire et al. [10] } & \multicolumn{4}{|c|}{ Model 2: Alternative empowerment gap based on approach 1} & \multicolumn{4}{|c|}{ Model 3: Alternative empowerment gap based on approach 2} \\
\hline & $\begin{array}{l}\text { Productivity } \\
\text { change }\end{array}$ & $\begin{array}{l}\text { Efficiency } \\
\text { change }\end{array}$ & $\begin{array}{l}\text { Technical } \\
\text { change }\end{array}$ & $\begin{array}{l}\text { Scale } \\
\text { efficiency } \\
\text { change }\end{array}$ & $\begin{array}{l}\text { Productivity } \\
\text { change }\end{array}$ & $\begin{array}{l}\text { Efficiency } \\
\text { change }\end{array}$ & $\begin{array}{l}\text { Technical } \\
\text { change }\end{array}$ & $\begin{array}{l}\text { Scale } \\
\text { efficiency } \\
\text { change }\end{array}$ & $\begin{array}{l}\text { Productivity } \\
\text { change }\end{array}$ & $\begin{array}{l}\text { Efficiency } \\
\text { change }\end{array}$ & $\begin{array}{l}\text { Technical } \\
\text { change }\end{array}$ & $\begin{array}{l}\text { Scale } \\
\text { efficiency } \\
\text { change }\end{array}$ \\
\hline \multirow[t]{2}{*}{ Empowerment gap } & $-0.128 * *$ & -0.105 & -0.027 & 0.002 & $-0.182^{*}$ & -0.224 & $\begin{array}{l}-0.016 \\
\end{array}$ & -0.007 & $\begin{array}{ll}-0.117 \\
\end{array}$ & -0.123 & -0.013 & -0.001 \\
\hline & $(0.063)$ & $(0.094)$ & $(0.018)$ & $(0.030)$ & (0.109) & $(0.157)$ & $(0.028)$ & $(0.054)$ & $(0.077)$ & $(0.112)$ & $(0.021)$ & $(0.033)$ \\
\hline \multirow[t]{2}{*}{ Sex } & -0.097 & -0.085 & $-0.034 *$ & 0.018 & -0.102 & -0.093 & $-0.034 *$ & 0.018 & -0.102 & -0.091 & $-0.034 *$ & 0.018 \\
\hline & $(0.070)$ & $(0.107)$ & $(0.020)$ & $(0.025)$ & $(0.071)$ & $(0.110)$ & $(0.019)$ & $(0.026)$ & $(0.069)$ & $(0.107)$ & $(0.020)$ & $(0.026)$ \\
\hline \multirow[t]{2}{*}{ Age } & 0.001 & 0.001 & 0.000 & 0.000 & 0.001 & 0.001 & 0.000 & 0.000 & 0.001 & 0.001 & 0.000 & 0.000 \\
\hline & $(0.001)$ & $(0.001)$ & $(0.000)$ & $(0.000)$ & $(0.001)$ & $(0.001)$ & $(0.000)$ & $(0.000)$ & $(0.001)$ & $(0.001)$ & $(0.000)$ & $(0.000)$ \\
\hline \multirow[t]{2}{*}{ Education } & 0.002 & -0.004 & $0.002 *$ & $0.004^{*}$ & 0.002 & -0.003 & $0.002 *$ & 0.004 & 0.002 & -0.004 & $0.002^{*}$ & $0.004 *$ \\
\hline & $(0.003)$ & $(0.005)$ & $(0.001)$ & $(0.002)$ & $(0.003)$ & $(0.005)$ & $(0.001)$ & $(0.003)$ & $(0.003)$ & $(0.005)$ & $(0.001)$ & $(0.002)$ \\
\hline \multirow[t]{2}{*}{ Dependency ratio } & $-0.049 * *$ & $-0.056 * *$ & -0.008 & -0.006 & $-0.049 * *$ & $-0.057 * *$ & -0.008 & -0.006 & $-0.049 * *$ & $-0.056 * *$ & -0.008 & -0.006 \\
\hline & $(0.019)$ & $(0.028)$ & $(0.005)$ & $(0.011)$ & $(0.019)$ & $(0.028)$ & $(0.005)$ & $(0.012)$ & $(0.019)$ & $(0.028)$ & $(0.005)$ & $(0.011)$ \\
\hline \multirow[t]{2}{*}{ Household size } & -0.014 & $-0.020^{*}$ & 0.001 & $-0.005^{* *}$ & -0.014 & $-0.020^{*}$ & 0.001 & $-0.005^{* *}$ & -0.014 & $-0.020^{*}$ & 0.001 & $-0.005 * *$ \\
\hline & $(0.009)$ & $(0.011)$ & $(0.002)$ & $(0.002)$ & $(0.009)$ & $(0.012)$ & $(0.003)$ & $(0.002)$ & $(0.009)$ & $(0.011)$ & $(0.003)$ & $(0.002)$ \\
\hline \multirow[t]{2}{*}{ Extension visit } & 0.013 & -0.004 & 0.007 & 0.004 & 0.013 & -0.004 & 0.007 & 0.004 & 0.013 & -0.004 & 0.007 & 0.004 \\
\hline & $(0.021)$ & $(0.013)$ & $(0.009)$ & $(0.004)$ & $(0.021)$ & $(0.013)$ & $(0.010)$ & $(0.004)$ & $(0.021)$ & $(0.013)$ & $(0.010)$ & $(0.004)$ \\
\hline \multirow{2}{*}{$\begin{array}{l}\text { Income share from non ag. } \\
\text { enterprise }\end{array}$} & 0.052 & $0.113 * *$ & -0.010 & -0.010 & 0.054 & $0.115^{* *}$ & -0.010 & -0.010 & 0.053 & $0.114 * *$ & -0.010 & -0.010 \\
\hline & $(0.037)$ & $(0.055)$ & $(0.009)$ & $(0.017)$ & $(0.036)$ & $(0.055)$ & $(0.009)$ & $(0.017)$ & $(0.037)$ & $(0.055)$ & $(0.009)$ & $(0.018)$ \\
\hline \multirow[t]{2}{*}{ Rainfed } & 0.023 & 0.028 & 0.002 & -0.004 & 0.025 & 0.031 & 0.002 & -0.004 & 0.023 & 0.028 & 0.001 & -0.004 \\
\hline & $(0.025)$ & $(0.035)$ & $(0.006)$ & $(0.012)$ & $(0.024)$ & $(0.035)$ & $(0.006)$ & $(0.011)$ & $(0.025)$ & $(0.035)$ & $(0.006)$ & $(0.011)$ \\
\hline \multirow[t]{2}{*}{ Tenancy } & $0.061 * *$ & 0.059 & $0.012^{* *}$ & 0.011 & $0.060^{* *}$ & 0.059 & $0.012 * *$ & 0.011 & $0.060^{* *}$ & 0.059 & $0.012^{* *}$ & 0.011 \\
\hline & $(0.026)$ & $(0.037)$ & $(0.005)$ & $(0.017)$ & $(0.026)$ & $(0.037)$ & $(0.005)$ & $(0.018)$ & $(0.026)$ & $(0.037)$ & $(0.005)$ & $(0.017)$ \\
\hline \multirow[t]{2}{*}{ Rainfall } & $-0.000 *$ & -0.000 & $-0.000 * * *$ & $0.000^{*}$ & $-0.000^{* *}$ & -0.000 & $-0.000^{* * *}$ & $0.000 *$ & $-0.000^{* *}$ & -0.000 & $-0.000^{* * * *}$ & $0.000^{*}$ \\
\hline & $(0.000)$ & $(0.000)$ & $(0.000)$ & $(0.000)$ & $(0.000)$ & $(0.000)$ & $(0.000)$ & $(0.000)$ & $(0.000)$ & $(0.000)$ & $(0.000)$ & $(0.000)$ \\
\hline \multirow[t]{2}{*}{ Temperature } & $0.249^{* * * *}$ & 0.222 & $0.070^{* * *}$ & -0.007 & $0.251^{* * *}$ & $0.233^{*}$ & $0.067 * * *$ & -0.005 & $0.246^{* * * *}$ & $0.224 *$ & $0.067^{* * * *}$ & -0.006 \\
\hline & $(0.091)$ & $(0.135)$ & $(0.024)$ & $(0.026)$ & $(0.091)$ & $(0.135)$ & $(0.023)$ & $(0.025)$ & $(0.090)$ & $(0.134)$ & $(0.024)$ & $(0.026)$ \\
\hline \multirow[t]{2}{*}{ Northwest } & 0.033 & -0.019 & $0.024 * * *$ & 0.035 & 0.037 & -0.014 & $0.025^{* * *}$ & 0.035 & 0.032 & -0.019 & $0.024^{* * * *}$ & 0.035 \\
\hline & $(0.034)$ & $(0.047)$ & $(0.008)$ & $(0.024)$ & $(0.034)$ & $(0.048)$ & $(0.008)$ & $(0.025)$ & $(0.034)$ & $(0.048)$ & $(0.008)$ & $(0.024)$ \\
\hline \multirow[t]{2}{*}{ Southwest } & -0.050 & -0.004 & $-0.029 * * *$ & 0.001 & -0.048 & -0.000 & $-0.029 * * *$ & 0.001 & -0.053 & -0.006 & $-0.030^{\text {**** }}$ & 0.001 \\
\hline & $(0.038)$ & $(0.054)$ & $(0.010)$ & $(0.010)$ & $(0.038)$ & $(0.055)$ & $(0.011)$ & $(0.010)$ & $(0.038)$ & $(0.053)$ & $(0.011)$ & $(0.010)$ \\
\hline \multirow[t]{2}{*}{ Northeast } & $0.165^{* * *}$ & $0.150^{*}$ & $0.052 * * *$ & -0.024 & $0.166^{* * * *}$ & $0.153^{*}$ & $0.052^{* * *}$ & -0.023 & $0.170^{* * *}$ & $0.156^{*}$ & $0.053^{* * * *}$ & -0.024 \\
\hline & $(0.059)$ & $(0.087)$ & $(0.015)$ & $(0.022)$ & $(0.058)$ & $(0.088)$ & $(0.014)$ & $(0.022)$ & $(0.058)$ & $(0.089)$ & $(0.015)$ & $(0.022)$ \\
\hline \multirow[t]{2}{*}{ Constant } & $0.635^{* * *}$ & $1.099 * * *$ & $0.583^{* * *}$ & $1.051^{* * *}$ & $0.630^{* * *}$ & $1.095^{* * *}$ & $0.582 * * *$ & $1.051^{* * *}$ & $0.634^{* * * *}$ & $1.098^{* * *}$ & $0.583^{* * * *}$ & $1.051^{* * * *}$ \\
\hline & $(0.083)$ & $(0.119)$ & $(0.020)$ & $(0.036)$ & $(0.082)$ & $(0.119)$ & $(0.021)$ & $(0.035)$ & $(0.084)$ & $(0.120)$ & $(0.021)$ & $(0.036)$ \\
\hline
\end{tabular}


Supplement S3 Table 2. Results of the OLS bootstrap regression of the determinants of farm productivity change and its components (WEAI domains)

\begin{tabular}{|c|c|c|c|c|c|c|c|c|c|c|c|c|}
\hline \multirow[b]{2}{*}{ Variables } & \multicolumn{4}{|c|}{$\begin{array}{l}\text { Model 1: Empowerment domain score based on Alkire et al. } \\
\text { [10] }\end{array}$} & \multicolumn{4}{|c|}{$\begin{array}{l}\text { Model 2: Alternative empowerment domain score } \\
\text { based on approach } 1\end{array}$} & \multicolumn{4}{|c|}{$\begin{array}{l}\text { Model 3: Alternative empowerment domain score based on } \\
\text { approach } 2\end{array}$} \\
\hline & $\begin{array}{l}\text { Productivity } \\
\text { change }\end{array}$ & $\begin{array}{l}\text { Efficiency } \\
\text { change }\end{array}$ & $\begin{array}{l}\text { Technical } \\
\text { change }\end{array}$ & $\begin{array}{l}\text { Scale } \\
\text { efficiency } \\
\text { change }\end{array}$ & $\begin{array}{l}\text { Productivit } \\
\text { y change }\end{array}$ & $\begin{array}{l}\text { Efficiency } \\
\text { change }\end{array}$ & $\begin{array}{l}\text { Technical } \\
\text { change }\end{array}$ & $\begin{array}{l}\text { Scale } \\
\text { efficiency } \\
\text { change }\end{array}$ & $\begin{array}{l}\text { Productivity } \\
\text { change }\end{array}$ & $\begin{array}{l}\text { Efficiency } \\
\text { change }\end{array}$ & $\begin{array}{l}\text { Technical } \\
\text { change }\end{array}$ & $\begin{array}{l}\text { Scale } \\
\text { efficiency } \\
\text { change }\end{array}$ \\
\hline Empowerment score: Production & $\begin{array}{l}0.483^{* * *} \\
(0.168)\end{array}$ & $\begin{array}{l}0.458^{*} \\
(0.241)\end{array}$ & $\begin{array}{l}0.115^{* * * *} \\
(0.041)\end{array}$ & $\begin{array}{l}0.038 \\
(0.090)\end{array}$ & $\begin{array}{l}0.798^{* * * *} \\
(0.233)\end{array}$ & $\begin{array}{l}0.885 * * * \\
(0.329)\end{array}$ & $\begin{array}{l}0.121^{* *} \\
(0.054)\end{array}$ & $\begin{array}{l}0.147 \\
(0.179)\end{array}$ & $\begin{array}{l}0.762^{* * * *} \\
(0.217)\end{array}$ & $\begin{array}{l}0.838^{* * *} \\
(0.314)\end{array}$ & $\begin{array}{l}0.120^{* *} \\
(0.049)\end{array}$ & $\begin{array}{l}0.132 \\
(0.174)\end{array}$ \\
\hline Empowerment score: Resource & $\begin{array}{l}0.064 \\
(0.179)\end{array}$ & $\begin{array}{l}0.091 \\
(0.265)\end{array}$ & $\begin{array}{l}0.041 \\
(0.042)\end{array}$ & $\begin{array}{l}-0.067 \\
(0.058)\end{array}$ & $\begin{array}{l}0.843 \\
(0.593)\end{array}$ & $\begin{array}{l}0.919 \\
(0.837)\end{array}$ & $\begin{array}{l}-0.080 \\
(0.142)\end{array}$ & $\begin{array}{l}0.677 \\
(0.542)\end{array}$ & $\begin{array}{l}0.412 * * \\
(0.199)\end{array}$ & $\begin{array}{l}0.500^{*} \\
(0.303)\end{array}$ & $\begin{array}{l}0.047 \\
(0.049)\end{array}$ & $\begin{array}{l}0.014 \\
(0.084)\end{array}$ \\
\hline Empowerment score: Income & $\begin{array}{l}-0.010 \\
(0.140)\end{array}$ & $\begin{array}{l}-0.075 \\
(0.211)\end{array}$ & $\begin{array}{l}-0.021 \\
(0.034)\end{array}$ & $\begin{array}{l}0.026 \\
(0.044)\end{array}$ & $\begin{array}{l}-0.091 \\
(0.413)\end{array}$ & $\begin{array}{l}-0.255 \\
(0.583)\end{array}$ & $\begin{array}{l}0.124 \\
(0.083)\end{array}$ & $\begin{array}{l}-0.311 \\
(0.247)\end{array}$ & $\begin{array}{l}-0.101 \\
(0.239)\end{array}$ & $\begin{array}{l}-0.181 \\
(0.336)\end{array}$ & $\begin{array}{l}0.014 \\
(0.054)\end{array}$ & $\begin{array}{l}-0.132 \\
(0.124)\end{array}$ \\
\hline Empowerment score: Leadership & $\begin{array}{l}0.096 \\
(0.205)\end{array}$ & $\begin{array}{l}0.224 \\
(0.275)\end{array}$ & $\begin{array}{l}0.033 \\
(0.053)\end{array}$ & $\begin{array}{l}-0.196^{*} \\
(0.103)\end{array}$ & $\begin{array}{l}0.314 \\
(0.574)\end{array}$ & $\begin{array}{l}0.576 \\
(0.806)\end{array}$ & $\begin{array}{l}0.047 \\
(0.118)\end{array}$ & $\begin{array}{l}-0.472 \\
(0.348)\end{array}$ & $\begin{array}{l}-0.087 \\
(0.249)\end{array}$ & $\begin{array}{l}0.092 \\
(0.330)\end{array}$ & $\begin{array}{l}-0.024 \\
(0.064)\end{array}$ & $\begin{array}{l}-0.217 \\
(0.133)\end{array}$ \\
\hline Empowerment score: Time & $\begin{array}{l}0.196 \\
(0.172)\end{array}$ & $\begin{array}{l}0.174 \\
(0.258)\end{array}$ & $\begin{array}{l}0.016 \\
(0.042)\end{array}$ & $\begin{array}{l}0.083 \\
(0.078)\end{array}$ & $\begin{array}{l}0.253 \\
(0.205)\end{array}$ & $\begin{array}{l}0.293 \\
(0.298)\end{array}$ & $\begin{array}{l}0.008 \\
(0.049)\end{array}$ & $\begin{array}{l}0.112 \\
(0.119)\end{array}$ & $\begin{array}{l}0.187 \\
(0.171)\end{array}$ & $\begin{array}{l}0.167 \\
(0.255)\end{array}$ & $\begin{array}{l}0.017 \\
(0.042)\end{array}$ & $\begin{array}{l}0.077 \\
(0.080)\end{array}$ \\
\hline Sex & $\begin{array}{l}-0.113 \\
(0.070)\end{array}$ & $\begin{array}{l}-0.102 \\
(0.110)\end{array}$ & $\begin{array}{l}-0.039^{* *} \\
(0.020)\end{array}$ & $\begin{array}{l}0.018 \\
(0.026)\end{array}$ & $\begin{array}{l}-0.123^{*} \\
(0.073)\end{array}$ & $\begin{array}{l}-0.110 \\
(0.113)\end{array}$ & $\begin{array}{l}-0.038^{* *} \\
(0.019)\end{array}$ & $\begin{array}{l}0.012 \\
(0.027)\end{array}$ & $\begin{array}{l}-0.125^{*} \\
(0.072)\end{array}$ & $\begin{array}{l}-0.117 \\
(0.112)\end{array}$ & $\begin{array}{l}-0.039^{*} \\
(0.020)\end{array}$ & $\begin{array}{l}0.020 \\
(0.026)\end{array}$ \\
\hline Age & $\begin{array}{l}0.001 \\
(0.001)\end{array}$ & $\begin{array}{l}0.001 \\
(0.001)\end{array}$ & $\begin{array}{l}0.000 \\
(0.000)\end{array}$ & $\begin{array}{l}-0.000 \\
(0.000)\end{array}$ & $\begin{array}{l}0.001 \\
(0.001)\end{array}$ & $\begin{array}{l}0.001 \\
(0.001)\end{array}$ & $\begin{array}{l}0.000 \\
(0.000)\end{array}$ & $\begin{array}{l}0.000 \\
(0.000)\end{array}$ & $\begin{array}{l}0.001 \\
(0.001)\end{array}$ & $\begin{array}{l}0.001 \\
(0.001)\end{array}$ & $\begin{array}{l}0.000 \\
(0.000)\end{array}$ & $\begin{array}{l}0.000 \\
(0.000)\end{array}$ \\
\hline Education & $\begin{array}{l}0.001 \\
(0.003)\end{array}$ & $\begin{array}{l}-0.004 \\
(0.005)\end{array}$ & $\begin{array}{l}0.001 * \\
(0.001)\end{array}$ & $\begin{array}{l}0.004 * \\
(0.002)\end{array}$ & $\begin{array}{l}0.001 \\
(0.003)\end{array}$ & $\begin{array}{l}-0.005 \\
(0.005)\end{array}$ & $\begin{array}{l}0.002^{*} \\
(0.001)\end{array}$ & $\begin{array}{l}0.004^{*} \\
(0.002)\end{array}$ & $\begin{array}{l}0.001 \\
(0.003)\end{array}$ & $\begin{array}{l}-0.005 \\
(0.005)\end{array}$ & $\begin{array}{l}0.001^{*} \\
(0.001)\end{array}$ & $\begin{array}{l}0.004^{*} \\
(0.002)\end{array}$ \\
\hline Dependency ratio & $\begin{array}{l}-0.046^{* * *} \\
(0.019)\end{array}$ & $\begin{array}{l}-0.053^{*} \\
(0.028)\end{array}$ & $\begin{array}{l}-0.007 \\
(0.005)\end{array}$ & $\begin{array}{l}-0.007 \\
(0.011)\end{array}$ & $\begin{array}{l}-0.045^{* *} \\
(0.019)\end{array}$ & $\begin{array}{l}-0.051^{*} \\
(0.029)\end{array}$ & $\begin{array}{l}-0.008^{*} \\
(0.005)\end{array}$ & $\begin{array}{l}-0.005 \\
(0.011)\end{array}$ & $\begin{array}{l}-0.047 * * \\
(0.019)\end{array}$ & $\begin{array}{l}-0.053^{*} \\
(0.028)\end{array}$ & $\begin{array}{l}-0.007 \\
(0.005)\end{array}$ & $\begin{array}{l}-0.006 \\
(0.011)\end{array}$ \\
\hline Household Size & $\begin{array}{l}-0.014 \\
(0.009)\end{array}$ & $\begin{array}{l}-0.021 * \\
(0.012)\end{array}$ & $\begin{array}{l}0.001 \\
(0.002)\end{array}$ & $\begin{array}{l}-0.005^{*} \\
(0.002)\end{array}$ & $\begin{array}{l}-0.014 \\
(0.009)\end{array}$ & $\begin{array}{l}-0.020^{*} \\
(0.012)\end{array}$ & $\begin{array}{l}0.001 \\
(0.002)\end{array}$ & $\begin{array}{l}-0.005^{*} \\
(0.003)\end{array}$ & $\begin{array}{l}-0.013 \\
(0.009)\end{array}$ & $\begin{array}{l}-0.019 \\
(0.012)\end{array}$ & $\begin{array}{l}0.001 \\
(0.003)\end{array}$ & $\begin{array}{l}-0.005^{*} \\
(0.002)\end{array}$ \\
\hline Extension visit & $\begin{array}{l}0.013 \\
(0.021)\end{array}$ & $\begin{array}{l}-0.005 \\
(0.013)\end{array}$ & $\begin{array}{l}0.007 \\
(0.010)\end{array}$ & $\begin{array}{l}0.004 \\
(0.004)\end{array}$ & $\begin{array}{l}0.012 \\
(0.021)\end{array}$ & $\begin{array}{l}-0.006 \\
(0.013)\end{array}$ & $\begin{array}{l}0.007 \\
(0.010)\end{array}$ & $\begin{array}{l}0.004 \\
(0.004)\end{array}$ & $\begin{array}{l}0.012 \\
(0.021)\end{array}$ & $\begin{array}{l}-0.005 \\
(0.013)\end{array}$ & $\begin{array}{l}0.007 \\
(0.010)\end{array}$ & $\begin{array}{l}0.004 \\
(0.004)\end{array}$ \\
\hline $\begin{array}{l}\text { Income share from non ag. } \\
\text { enterprise }\end{array}$ & $\begin{array}{l}0.054 \\
(0.037)\end{array}$ & $\begin{array}{l}0.114 * * \\
(0.055)\end{array}$ & $\begin{array}{l}-0.010 \\
(0.009)\end{array}$ & $\begin{array}{l}-0.008 \\
(0.017)\end{array}$ & $\begin{array}{l}0.054 \\
(0.037)\end{array}$ & $\begin{array}{l}0.115^{* *} \\
(0.055)\end{array}$ & $\begin{array}{l}-0.010 \\
(0.009)\end{array}$ & $\begin{array}{l}-0.008 \\
(0.017)\end{array}$ & $\begin{array}{l}0.058 \\
(0.037)\end{array}$ & $\begin{array}{l}0.118^{* *} \\
(0.055)\end{array}$ & $\begin{array}{l}-0.009 \\
(0.009)\end{array}$ & $\begin{array}{l}-0.007 \\
(0.017)\end{array}$ \\
\hline Rainfed & $\begin{array}{l}-0.018 \\
(0.024)\end{array}$ & $\begin{array}{l}-0.011 \\
(0.034)\end{array}$ & $\begin{array}{l}-0.004 \\
(0.006)\end{array}$ & $\begin{array}{l}-0.009 \\
(0.011)\end{array}$ & $\begin{array}{l}-0.018 \\
(0.024)\end{array}$ & $\begin{array}{l}-0.010 \\
(0.034)\end{array}$ & $\begin{array}{l}-0.003 \\
(0.006)\end{array}$ & $\begin{array}{l}-0.011 \\
(0.012)\end{array}$ & $\begin{array}{l}-0.019 \\
(0.024)\end{array}$ & $\begin{array}{l}-0.012 \\
(0.034)\end{array}$ & $\begin{array}{l}-0.004 \\
(0.006)\end{array}$ & $\begin{array}{l}-0.010 \\
(0.012)\end{array}$ \\
\hline Tenancy & $\begin{array}{l}0.049^{*} \\
(0.025)\end{array}$ & $\begin{array}{l}0.030 \\
(0.036)\end{array}$ & $\begin{array}{l}0.015^{* * * *} \\
(0.006)\end{array}$ & $\begin{array}{l}0.016 \\
(0.018)\end{array}$ & $\begin{array}{l}0.049^{*} \\
(0.025)\end{array}$ & $\begin{array}{l}0.029 \\
(0.036)\end{array}$ & $\begin{array}{l}0.015^{* * * *} \\
(0.005)\end{array}$ & $\begin{array}{l}0.017 \\
(0.019)\end{array}$ & $\begin{array}{l}0.050^{* *} \\
(0.025)\end{array}$ & $\begin{array}{l}0.031 \\
(0.036)\end{array}$ & $\begin{array}{l}0.015^{* * * *} \\
(0.006)\end{array}$ & $\begin{array}{l}0.015 \\
(0.018)\end{array}$ \\
\hline Rainfall & $\begin{array}{l}-0.000 \\
(0.000)\end{array}$ & $\begin{array}{l}-0.000 \\
(0.000)\end{array}$ & $\begin{array}{l}-0.000^{* * *} \\
(0.000)\end{array}$ & $\begin{array}{l}0.000^{*} \\
(0.000)\end{array}$ & $\begin{array}{l}-0.000^{*} \\
(0.000)\end{array}$ & $\begin{array}{l}-0.000 \\
(0.000)\end{array}$ & $\begin{array}{l}-0.000^{* * *} \\
(0.000)\end{array}$ & $\begin{array}{l}0.000 \\
(0.000)\end{array}$ & $\begin{array}{l}-0.000^{*} \\
(0.000)\end{array}$ & $\begin{array}{l}-0.000 \\
(0.000)\end{array}$ & $\begin{array}{l}-0.000 * * * \\
(0.000)\end{array}$ & $\begin{array}{l}0.000^{*} \\
(0.000)\end{array}$ \\
\hline Temperature & $\begin{array}{l}0.236 * * * \\
(0.091)\end{array}$ & $\begin{array}{l}0.214 \\
(0.136)\end{array}$ & $\begin{array}{l}0.070^{* * * *} \\
(0.024)\end{array}$ & $\begin{array}{l}-0.015 \\
(0.027)\end{array}$ & $\begin{array}{l}0.246 * * * \\
(0.091)\end{array}$ & $\begin{array}{l}0.227^{*} \\
(0.137)\end{array}$ & $\begin{array}{l}0.064 * * * \\
(0.023)\end{array}$ & $\begin{array}{l}0.004 \\
(0.025)\end{array}$ & $\begin{array}{l}0.241^{* * *} \\
(0.090)\end{array}$ & $\begin{array}{l}0.225 \\
(0.137)\end{array}$ & $\begin{array}{l}0.067 * * * \\
(0.024)\end{array}$ & $\begin{array}{l}-0.013 \\
(0.027)\end{array}$ \\
\hline Northwest & $\begin{array}{l}0.040 \\
(0.034)\end{array}$ & $\begin{array}{l}-0.015 \\
(0.047)\end{array}$ & $\begin{array}{l}0.026 * * * \\
(0.008)\end{array}$ & $\begin{array}{l}0.039 \\
(0.027)\end{array}$ & $\begin{array}{l}0.044 \\
(0.034)\end{array}$ & $\begin{array}{l}-0.008 \\
(0.048)\end{array}$ & $\begin{array}{l}0.028 * * * \\
(0.008)\end{array}$ & $\begin{array}{l}0.034 \\
(0.024)\end{array}$ & $\begin{array}{l}0.049 \\
(0.035)\end{array}$ & $\begin{array}{l}-0.006 \\
(0.048)\end{array}$ & $\begin{array}{l}0.027 * * * \\
(0.008)\end{array}$ & $\begin{array}{l}0.040 \\
(0.029)\end{array}$ \\
\hline Southwest & $\begin{array}{l}-0.035 \\
(0.038)\end{array}$ & $\begin{array}{l}0.008 \\
(0.054)\end{array}$ & $\begin{array}{l}-0.027^{* *} \\
(0.011)\end{array}$ & $\begin{array}{l}0.007 \\
(0.011)\end{array}$ & $\begin{array}{l}-0.032 \\
(0.038)\end{array}$ & $\begin{array}{l}0.013 \\
(0.056)\end{array}$ & $\begin{array}{l}-0.024 * * \\
(0.010)\end{array}$ & $\begin{array}{l}-0.002 \\
(0.010)\end{array}$ & $\begin{array}{l}-0.031 \\
(0.039)\end{array}$ & $\begin{array}{l}0.012 \\
(0.054)\end{array}$ & $\begin{array}{l}-0.026^{* *} \\
(0.011)\end{array}$ & $\begin{array}{l}0.007 \\
(0.012)\end{array}$ \\
\hline Northeast & $\begin{array}{l}0.156^{* * * *} \\
(0.057)\end{array}$ & $\begin{array}{l}0.142 * \\
(0.086)\end{array}$ & $\begin{array}{l}0.054 * * * \\
(0.015)\end{array}$ & $\begin{array}{l}-0.027 \\
(0.022)\end{array}$ & $\begin{array}{l}0.174 * * * \\
(0.058)\end{array}$ & $\begin{array}{l}0.162^{*} \\
(0.087)\end{array}$ & $\begin{array}{l}0.049 * * * \\
(0.015)\end{array}$ & $\begin{array}{l}-0.005 \\
(0.022)\end{array}$ & $\begin{array}{l}0.174 * * * \\
(0.057)\end{array}$ & $\begin{array}{l}0.166^{*} \\
(0.087)\end{array}$ & $\begin{array}{l}0.054 * * * \\
(0.015)\end{array}$ & $\begin{array}{l}-0.023 \\
(0.022)\end{array}$ \\
\hline Constant & $\begin{array}{l}0.554 * * * \\
(0.092)\end{array}$ & $\begin{array}{l}1.028^{* * * *} \\
(0.136)\end{array}$ & $\begin{array}{l}0.563^{* * * *} \\
(0.025)\end{array}$ & $\begin{array}{l}1.056 * * * \\
(0.036)\end{array}$ & $\begin{array}{l}0.514 * * * \\
(0.089)\end{array}$ & $\begin{array}{l}0.971 * * * \\
(0.130)\end{array}$ & $\begin{array}{l}0.571 \text { *** } \\
(0.023)\end{array}$ & $\begin{array}{l}1.014 * * * \\
(0.037)\end{array}$ & $\begin{array}{l}0.490^{* * *} \\
(0.092)\end{array}$ & $\begin{array}{l}0.940 * * * \\
(0.135)\end{array}$ & $\begin{array}{l}0.560^{* * *} \\
(0.024)\end{array}$ & $\begin{array}{l}1.050^{* * * *} \\
(0.035)\end{array}$ \\
\hline
\end{tabular}

Note: Standard errors in parentheses; *,**, and *** indicate significance based on $90 \%, 95 \%$ and $99 \%$ bootstrap confidence level, respectively 
Supplement S3 Table 3. Results of the OLS bootstrap regression of the determinants of farm productivity change and its components (production domain indicators)

\begin{tabular}{|c|c|c|c|c|c|c|c|c|c|c|c|c|}
\hline \multirow[b]{2}{*}{ Variables } & \multicolumn{4}{|c|}{$\begin{array}{l}\text { Model 1: Production domain indicator based on Alkire } \\
\text { et al. [10] }\end{array}$} & \multicolumn{4}{|c|}{$\begin{array}{l}\text { Model 2: Alternative production domain } \\
\text { indicator based on approach } 1\end{array}$} & \multicolumn{4}{|c|}{$\begin{array}{l}\text { Model 3: Alternative production domain indicator } \\
\text { based on approach } 2\end{array}$} \\
\hline & $\begin{array}{l}\text { Productivity } \\
\text { change }\end{array}$ & $\begin{array}{l}\text { Efficiency } \\
\text { change }\end{array}$ & $\begin{array}{l}\text { Technical } \\
\text { change }\end{array}$ & $\begin{array}{l}\text { Scale } \\
\text { efficiency } \\
\text { change }\end{array}$ & $\begin{array}{l}\text { Productivit } \\
\text { y change }\end{array}$ & $\begin{array}{l}\text { Efficienc } \\
\text { y change }\end{array}$ & $\begin{array}{l}\text { Technical } \\
\text { change }\end{array}$ & $\begin{array}{l}\text { Scale } \\
\text { efficienc } \\
\text { y change }\end{array}$ & $\begin{array}{l}\text { Productivit } \\
\text { y change }\end{array}$ & $\begin{array}{l}\text { Efficiency } \\
\text { change }\end{array}$ & $\begin{array}{l}\text { Technical } \\
\text { change }\end{array}$ & $\begin{array}{l}\text { Scale } \\
\text { efficiency } \\
\text { change }\end{array}$ \\
\hline Input in productive decisions & $\begin{array}{l}0.045 \\
(0.237)\end{array}$ & $\begin{array}{l}-0.220 \\
(0.351)\end{array}$ & $\begin{array}{l}0.087 \\
(0.064)\end{array}$ & $\begin{array}{l}-0.017 \\
(0.087)\end{array}$ & $\begin{array}{l}0.564 \\
(0.712)\end{array}$ & $\begin{array}{l}-0.102 \\
(0.993)\end{array}$ & $\begin{array}{l}0.390 * * * \\
(0.144)\end{array}$ & $\begin{array}{l}0.040 \\
(0.308)\end{array}$ & $\begin{array}{l}0.175 \\
(0.484)\end{array}$ & $\begin{array}{l}-0.058 \\
(0.713)\end{array}$ & $\begin{array}{l}0.071 \\
(0.113)\end{array}$ & $\begin{array}{l}0.093 \\
(0.269)\end{array}$ \\
\hline Autonomy in production & $\begin{array}{l}0.944 * * * \\
(0.239)\end{array}$ & $\begin{array}{l}1.121 * * * \\
(0.338)\end{array}$ & $\begin{array}{l}0.133 * * \\
(0.056)\end{array}$ & $\begin{array}{l}0.094 \\
(0.130)\end{array}$ & $\begin{array}{l}0.896^{* * * *} \\
(0.240)\end{array}$ & $\begin{array}{l}1.101 * * * \\
(0.345)\end{array}$ & $\begin{array}{l}0.107 * \\
(0.057)\end{array}$ & $\begin{array}{l}0.088 \\
(0.120)\end{array}$ & $\begin{array}{l}0.945 * * * \\
(0.230)\end{array}$ & $\begin{array}{l}1.093 * * * \\
(0.333)\end{array}$ & $\begin{array}{l}0.143 * * \\
(0.056)\end{array}$ & $\begin{array}{l}0.089 \\
(0.129)\end{array}$ \\
\hline Sex & $\begin{array}{l}-0.099 \\
(0.071)\end{array}$ & $\begin{array}{l}-0.082 \\
(0.112)\end{array}$ & $\begin{array}{l}-0.036^{*} \\
(0.019)\end{array}$ & $\begin{array}{l}0.017 \\
(0.025)\end{array}$ & $\begin{array}{l}-0.103 \\
(0.073)\end{array}$ & $\begin{array}{l}-0.085 \\
(0.113)\end{array}$ & $\begin{array}{l}-0.038^{* *} \\
(0.019)\end{array}$ & $\begin{array}{l}0.016 \\
(0.026)\end{array}$ & $\begin{array}{l}-0.101 \\
(0.070)\end{array}$ & $\begin{array}{l}-0.085 \\
(0.112)\end{array}$ & $\begin{array}{l}-0.036^{*} \\
(0.019)\end{array}$ & $\begin{array}{l}0.015 \\
(0.027)\end{array}$ \\
\hline Age & $\begin{array}{l}0.001 \\
(0.001)\end{array}$ & $\begin{array}{l}0.001 \\
(0.001)\end{array}$ & $\begin{array}{l}0.000 \\
(0.000)\end{array}$ & $\begin{array}{l}0.000 \\
(0.000)\end{array}$ & $\begin{array}{l}0.001 \\
(0.001)\end{array}$ & $\begin{array}{l}0.001 \\
(0.001)\end{array}$ & $\begin{array}{l}0.000 \\
(0.000)\end{array}$ & $\begin{array}{l}0.000 \\
(0.000)\end{array}$ & $\begin{array}{l}0.001 \\
(0.001)\end{array}$ & $\begin{array}{l}0.001 \\
(0.001)\end{array}$ & $\begin{array}{l}0.000 \\
(0.000)\end{array}$ & $\begin{array}{l}0.000 \\
(0.000)\end{array}$ \\
\hline Education & $\begin{array}{l}0.001 \\
(0.003)\end{array}$ & $\begin{array}{l}-0.004 \\
(0.005)\end{array}$ & $\begin{array}{l}0.002 * \\
(0.001)\end{array}$ & $\begin{array}{l}0.004 * \\
(0.002)\end{array}$ & $\begin{array}{l}0.001 \\
(0.003)\end{array}$ & $\begin{array}{l}-0.005 \\
(0.005)\end{array}$ & $\begin{array}{l}0.002 * \\
(0.001)\end{array}$ & $\begin{array}{l}0.004 * \\
(0.002)\end{array}$ & $\begin{array}{l}0.001 \\
(0.003)\end{array}$ & $\begin{array}{l}-0.005 \\
(0.005)\end{array}$ & $\begin{array}{l}0.002 * \\
(0.001)\end{array}$ & $\begin{array}{l}0.004^{*} \\
(0.002)\end{array}$ \\
\hline Dependency ratio & $\begin{array}{l}-0.046 * * \\
(0.019)\end{array}$ & $\begin{array}{l}-0.052^{*} \\
(0.028)\end{array}$ & $\begin{array}{l}-0.007 \\
(0.005)\end{array}$ & $\begin{array}{l}-0.006 \\
(0.011)\end{array}$ & $\begin{array}{l}-0.047 * * \\
(0.019)\end{array}$ & $\begin{array}{l}-0.053^{*} \\
(0.028)\end{array}$ & $\begin{array}{l}-0.008^{*} \\
(0.005)\end{array}$ & $\begin{array}{l}-0.006 \\
(0.011)\end{array}$ & $\begin{array}{l}-0.046^{* *} \\
(0.019)\end{array}$ & $\begin{array}{l}-0.053^{*} \\
(0.028)\end{array}$ & $\begin{array}{l}-0.007 \\
(0.005)\end{array}$ & $\begin{array}{l}-0.006 \\
(0.011)\end{array}$ \\
\hline Household Size & $\begin{array}{l}-0.016^{*} \\
(0.009)\end{array}$ & $\begin{array}{l}-0.022^{*} \\
(0.012)\end{array}$ & $\begin{array}{l}0.001 \\
(0.002)\end{array}$ & $\begin{array}{l}-0.006^{* *} \\
(0.003)\end{array}$ & $\begin{array}{l}-0.015^{*} \\
(0.009)\end{array}$ & $\begin{array}{l}-0.022^{*} \\
(0.012)\end{array}$ & $\begin{array}{l}0.001 \\
(0.002)\end{array}$ & $\begin{array}{l}-0.005 * * \\
(0.003)\end{array}$ & $\begin{array}{l}-0.016^{*} \\
(0.009)\end{array}$ & $\begin{array}{l}-0.022^{*} \\
(0.011)\end{array}$ & $\begin{array}{l}0.001 \\
(0.003)\end{array}$ & $\begin{array}{l}-0.005^{* * *} \\
(0.003)\end{array}$ \\
\hline Extension visit & $\begin{array}{l}0.012 \\
(0.021)\end{array}$ & $\begin{array}{l}-0.006 \\
(0.012)\end{array}$ & $\begin{array}{l}0.007 \\
(0.010)\end{array}$ & $\begin{array}{l}0.004 \\
(0.004)\end{array}$ & $\begin{array}{l}0.012 \\
(0.021)\end{array}$ & $\begin{array}{l}-0.006 \\
(0.013)\end{array}$ & $\begin{array}{l}0.007 \\
(0.010)\end{array}$ & $\begin{array}{l}0.004 \\
(0.004)\end{array}$ & $\begin{array}{l}0.012 \\
(0.021)\end{array}$ & $\begin{array}{l}-0.006 \\
(0.013)\end{array}$ & $\begin{array}{l}0.007 \\
(0.010)\end{array}$ & $\begin{array}{l}0.004 \\
(0.004)\end{array}$ \\
\hline $\begin{array}{l}\text { Income share from non ag. } \\
\text { enterprise }\end{array}$ & $\begin{array}{l}0.061 * \\
(0.037)\end{array}$ & $\begin{array}{l}0.126 * * \\
(0.056)\end{array}$ & $\begin{array}{l}-0.009 \\
(0.009)\end{array}$ & $\begin{array}{l}-0.010 \\
(0.017)\end{array}$ & $\begin{array}{l}0.060 \\
(0.037)\end{array}$ & $\begin{array}{l}0.125^{* *} \\
(0.055)\end{array}$ & $\begin{array}{l}-0.010 \\
(0.009)\end{array}$ & $\begin{array}{l}-0.010 \\
(0.018)\end{array}$ & $\begin{array}{l}0.062 * \\
(0.037)\end{array}$ & $\begin{array}{l}0.125^{* *} \\
(0.054)\end{array}$ & $\begin{array}{l}-0.009 \\
(0.009)\end{array}$ & $\begin{array}{l}-0.010 \\
(0.017)\end{array}$ \\
\hline Rainfed & $\begin{array}{l}-0.018 \\
(0.024)\end{array}$ & $\begin{array}{l}-0.010 \\
(0.034)\end{array}$ & $\begin{array}{l}-0.004 \\
(0.006)\end{array}$ & $\begin{array}{l}-0.010 \\
(0.012)\end{array}$ & $\begin{array}{l}-0.017 \\
(0.024)\end{array}$ & $\begin{array}{l}-0.010 \\
(0.034)\end{array}$ & $\begin{array}{l}-0.004 \\
(0.006)\end{array}$ & $\begin{array}{l}-0.010 \\
(0.011)\end{array}$ & $\begin{array}{l}-0.018 \\
(0.024)\end{array}$ & $\begin{array}{l}-0.009 \\
(0.035)\end{array}$ & $\begin{array}{l}-0.005 \\
(0.006)\end{array}$ & $\begin{array}{l}-0.010 \\
(0.011)\end{array}$ \\
\hline Tenancy & $\begin{array}{l}0.051 * * \\
(0.025)\end{array}$ & $\begin{array}{l}0.032 \\
(0.036)\end{array}$ & $\begin{array}{l}0.015 * * * \\
(0.006)\end{array}$ & $\begin{array}{l}0.016 \\
(0.018)\end{array}$ & $\begin{array}{l}0.051 * * \\
(0.025)\end{array}$ & $\begin{array}{l}0.032 \\
(0.036)\end{array}$ & $\begin{array}{l}0.015 * * * \\
(0.005)\end{array}$ & $\begin{array}{l}0.016 \\
(0.018)\end{array}$ & $\begin{array}{l}0.051 * * \\
(0.025)\end{array}$ & $\begin{array}{l}0.032 \\
(0.035)\end{array}$ & $\begin{array}{l}0.015^{* * * *} \\
(0.006)\end{array}$ & $\begin{array}{l}0.016 \\
(0.018)\end{array}$ \\
\hline Rainfall & $\begin{array}{l}-0.000^{*} \\
(0.000)\end{array}$ & $\begin{array}{l}-0.000 \\
(0.000)\end{array}$ & $\begin{array}{l}-0.000 * * * \\
(0.000)\end{array}$ & $\begin{array}{l}0.000^{*} \\
(0.000)\end{array}$ & $\begin{array}{l}-0.000 \\
(0.000)\end{array}$ & $\begin{array}{l}-0.000 \\
(0.000)\end{array}$ & $\begin{array}{l}-0.000 * * * \\
(0.000)\end{array}$ & $\begin{array}{l}0.000^{*} \\
(0.000)\end{array}$ & $\begin{array}{l}-0.000^{*} \\
(0.000)\end{array}$ & $\begin{array}{l}-0.000 \\
(0.000)\end{array}$ & $\begin{array}{l}-0.000 * * * \\
(0.000)\end{array}$ & $\begin{array}{l}0.000^{*} \\
(0.000)\end{array}$ \\
\hline Temperature & $\begin{array}{l}0.204 * * \\
(0.090)\end{array}$ & $\begin{array}{l}0.167 \\
(0.133)\end{array}$ & $\begin{array}{l}0.066 * * * \\
(0.023)\end{array}$ & $\begin{array}{l}-0.008 \\
(0.026)\end{array}$ & $\begin{array}{l}0.205 * * \\
(0.089)\end{array}$ & $\begin{array}{l}0.172 \\
(0.134)\end{array}$ & $\begin{array}{l}0.066 \text { *** } \\
(0.023)\end{array}$ & $\begin{array}{l}-0.008 \\
(0.027)\end{array}$ & $\begin{array}{l}0.204 * * \\
(0.089)\end{array}$ & $\begin{array}{l}0.172 \\
(0.134)\end{array}$ & $\begin{array}{l}0.065^{* * * *} \\
(0.023)\end{array}$ & $\begin{array}{l}-0.007 \\
(0.026)\end{array}$ \\
\hline Northwest & $\begin{array}{l}0.037 \\
(0.034)\end{array}$ & $\begin{array}{l}-0.015 \\
(0.047)\end{array}$ & $\begin{array}{l}0.026 * * * \\
(0.008)\end{array}$ & $\begin{array}{l}0.036 \\
(0.025)\end{array}$ & $\begin{array}{l}0.040 \\
(0.035)\end{array}$ & $\begin{array}{l}-0.015 \\
(0.048)\end{array}$ & $\begin{array}{l}0.028 * * * \\
(0.008)\end{array}$ & $\begin{array}{l}0.036 \\
(0.026)\end{array}$ & $\begin{array}{l}0.038 \\
(0.035)\end{array}$ & $\begin{array}{l}-0.015 \\
(0.048)\end{array}$ & $\begin{array}{l}0.026^{* * * *} \\
(0.008)\end{array}$ & $\begin{array}{l}0.037 \\
(0.026)\end{array}$ \\
\hline Southwest & $\begin{array}{l}-0.042 \\
(0.037)\end{array}$ & $\begin{array}{l}0.001 \\
(0.055)\end{array}$ & $\begin{array}{l}-0.027 * * * \\
(0.010)\end{array}$ & $\begin{array}{l}0.002 \\
(0.010)\end{array}$ & $\begin{array}{l}-0.036 \\
(0.038)\end{array}$ & $\begin{array}{l}0.002 \\
(0.054)\end{array}$ & $\begin{array}{l}-0.024 * * \\
(0.010)\end{array}$ & $\begin{array}{l}0.002 \\
(0.011)\end{array}$ & $\begin{array}{l}-0.041 \\
(0.037)\end{array}$ & $\begin{array}{l}0.003 \\
(0.054)\end{array}$ & $\begin{array}{l}-0.027 * * \\
(0.011)\end{array}$ & $\begin{array}{l}0.003 \\
(0.011)\end{array}$ \\
\hline Northeast & $\begin{array}{l}0.158 * * * \\
(0.057)\end{array}$ & $\begin{array}{l}0.144 * \\
(0.085)\end{array}$ & $\begin{array}{l}0.052 * * * \\
(0.015)\end{array}$ & $\begin{array}{l}-0.023 \\
(0.021)\end{array}$ & $\begin{array}{l}0.155^{* * * *} \\
(0.058)\end{array}$ & $\begin{array}{l}0.143 \\
(0.089)\end{array}$ & $\begin{array}{l}0.050 * * * \\
(0.015)\end{array}$ & $\begin{array}{l}-0.024 \\
(0.022)\end{array}$ & $\begin{array}{l}0.158 * * * \\
(0.057)\end{array}$ & $\begin{array}{l}0.142 \\
(0.087)\end{array}$ & $\begin{array}{l}0.053 * * * \\
(0.015)\end{array}$ & $\begin{array}{l}-0.024 \\
(0.021)\end{array}$ \\
\hline Constant & $\begin{array}{l}0.612 * * * \\
(0.083)\end{array}$ & $\begin{array}{l}1.092 * * * \\
(0.120)\end{array}$ & $\begin{array}{l}0.572 * * * \\
(0.021)\end{array}$ & $\begin{array}{l}1.049 * * * \\
(0.033)\end{array}$ & $\begin{array}{l}0.600 * * * \\
(0.083)\end{array}$ & $\begin{array}{l}1.082 * * * \\
(0.123)\end{array}$ & $\begin{array}{l}0.567 * * * \\
(0.021)\end{array}$ & $\begin{array}{l}1.047 * * * \\
(0.033)\end{array}$ & $\begin{array}{l}0.603 \text { *** } \\
(0.086)\end{array}$ & $\begin{array}{l}1.083 * * * \\
(0.129)\end{array}$ & $\begin{array}{l}0.572 * * * \\
(0.022)\end{array}$ & $\begin{array}{l}1.042 * * * \\
(0.029)\end{array}$ \\
\hline
\end{tabular}

Source: Authors calculations

$(0.120)$ 


\section{References}

1. Alkire S, Malapit H, Meinzen-Dick R, Peterman A, Quisumbing A, Seymour G, et al. Instructional Guide on the Women's Empowerment in Agriculture Index. Washington, DC: International Food Policy Research Institute (IFPRI); 2013 p. 82.

2. Food and Agriculture Organization. Women in agriculture: closing the gender gap for development. Rome, Italy; 2011. 147 p. (The state of food and agriculture).

3. Quisumbing AR. Male-female differences in agricultural productivity: Methodological issues and empirical evidence. World Dev. 1996 Oct 1;24(10):1579_ 95.

4. M. Rahman W, L. Parvin. Impact of Irrigation on Food Security in Bangladesh for the Past Three Decades. J Water Resour Prot [Internet]. 2009 Sep 21;2009. Available from: http://www.scirp.org/journal/PaperInformation.aspx?PaperID=687

5. Palmer-Jones RW. Sustaining Serendipity? Groundwater Irrigation, Growth of Agricultural Production, and Poverty in Bangladesh. Econ Polit Wkly. 1992;27(39):A128-40. 


\title{
Essay 3: Climate change-induced shifts in precipitation: response of Missouri corn and soybean basis
}

\begin{abstract}
:
We investigate the effect of different precipitation variables, namely local, growing season, and regional as well as their nonlinear interactions with Missouri corn and soybean basis using a large panel dataset for the 2010-2020 period. Our analysis reveals statistically significant linear and nonlinear basis responses for local and growing season precipitation variations. The estimates show that corn and soybean basis differ in terms of the immediate effect of normal or abnormal weekly rainfall captured by local precipitation variable whereas the growing season precipitation capturing the local supply effect exhibits a Ushaped relationship in both models. We also document a statistically significant moderating effect of port distance measure on the curvilinearity of the association between transportation disruptions proxied by regional precipitation and soybean basis. Given the climate projections, there are legitimate concerns regarding precipitation's influence on future navigability of major transportation arteries that link Missouri to export facilities down the Mississippi river. Hence, the information generated in this research has even greater utility when studied in the context of the role barge freight transportation plays in the state's agriculture.
\end{abstract}

Keywords: Basis; corn; soybean; precipitation; climate change; transportation 


\section{Introduction}

Current literature suggests that factors such as transportation cost, destination basis, ocean shipping spread [1,2], storage cost, local production, and contract maturity [3], ending stock and interest cost [4] affect commodity basis levels. One possible source of systematic variability in commodity basis that has not been considered so far in the literature is the effect of weather anomalies such as extreme or protracted precipitation events that result from climate change. There are growing concern and evidence that due to climate change, the intensity and frequency of weather events such as droughts and floods have increased in the US, and these events are adversely impacting crop growth, yield, and critical agricultural infrastructure [5-7]. Furthermore, some studies [8-10] imply that climate change might increase agricultural commodity prices by impacting yield. All these indicate a potential causal channel through which extreme climate events can influence commodity basis. In this study, we address how climate change, more specifically the risk from flooding and low flows, can affect the local corn and soybean basis levels.

Since agriculture and climate are intertwined, it is important to understand the consequences of changing global climate and how local climate variations might affect agricultural markets and prices. Although there are studies that demonstrate the link between commodity prices and climate variability, we find no attention has been given to the role of climate change in determining local basis levels. One particular reason that warrants the need for analyzing such a link is the extensive use of commodity basis in grain trading as a tool for risk hedging by the market participants. Therefore, understanding the basis and its determinants is crucial as increased basis variability may significantly increase 
traders' risk. Another reason is the role commodity basis plays in grain trade and movement. McKenzie [1] stated that commodity basis determines trade and grain flows. This value arises because basis is thought to be more readily predictable than futures or spot prices due to the convergence issue or the movement of the futures price towards the spot price as the contract expiration date approaches $[11,12]$. Furthermore, the local impact of climate change can be better understood by basis as local supply and demand conditions are more likely to be influenced by local basis than cash prices. All these indicate that basis is an important local pricing and allocation mechanism. Therefore, failure to account for the risk of climate change when explaining changes in basis may lead to a poorer understanding of basis fluctuations and this, in turn, may have negative consequences for market actors that engage in grain trading and even for producers through an income effect.

Climate change is projected to shift the precipitation regime in Missouri by increasing spring rainfall and average precipitation, and intensifying severe rainstorms, which is likely to affect the state's agriculture [5]. In this paper, the effect of climate change arising from changes in precipitation on the intertemporal price relationship between origin point cash price and delivery point futures price is empirically evaluated. More specifically, the effect of local, growing season, and regional precipitation on the Missouri corn and soybean basis levels is examined. We opt to focus on the corn and soybean basis as these commodities are widely distributed across the state and jointly account for more than a quarter of Missouri's agricultural exports [13]. Thus, understanding the implications of different intensities of precipitation patterns on corn and soybean basis has profound economic implications. However, the extrapolation is based on the key ceteris paribus 
assumption regarding infrastructure and market participants behavior, and we also assume that the historical weather pattern largely prevails.

This study contributes to the existing literature that examines the determinants of commodity basis. The approach employed here differs from that of earlier works in that it uses more detailed data on local price and precipitation. Along with precipitation data collected from elevator-specific local weather stations, growing season and corn belt precipitation data are used, which allows to capture the spatial variation in basis associated with local, growing season, and regional weather. Therefore, our basis modeling is relatively more robust as the empirical findings highlight the effect of marginal changes in specific precipitation patterns on the relationship between local cash and futures price.

The remainder of the paper is as follows. The literature on basis and climate change is reviewed in Section 2. In Section 3, we discuss the conceptual framework, empirical specifications, and data. A discussion on the empirical findings follows in Section 4, followed by the concluding remarks in Section 5 .

\section{Theoretical background and related literature}

\subsection{Basis}

Basis influences grain marketing and hedging effectiveness [14]. Earlier works by Kaldor [11], Working [12], and Brennan [15] and later by Williams [16] and Fama \& French $[17,18]$ explained commodity basis in terms of storage cost. This theory, called the theory of storage, states that the cash price of a commodity should stay below the futures contract by the cost of carrying the commodity from harvest to that specific contract month, and as the storage season progresses, cash prices should increase relative to the futures

prices. However, such cash-futures convergence may not always be perfect because of 
transaction costs (i.e., demurrage, interest costs) besides storage costs that limit arbitrage [19]. Since the futures market's performance depends on how smoothly this convergence occurs, several studies examined factors that could potentially expand the spread in CBOT grain futures and exacerbate convergence problem. The literature [20-22] that investigated convergence problems suggested that the wedge between the costs of holding delivery instruments and storing physical grain could be the primary source. Aulerich et al. [23] indicated that such non-convergence could also be associated with the fluctuations in the delivery options at expiration.

Empirical studies that focused on analyzing the determinants and volatility on basis behavior are also extensive. For example, Davis \& Hill [24] examined the spatial price differentials among Illinois country elevators and reported that seasonal adjustments, local demand and supply conditions, and transportation facilities' availability significantly affect such price relationships. Thompson et al. [25] used corn and soybean cash and futures prices to analyze the price relationship between and among terminal markets and reported that cash and futures price behavior differs between delivery and non-delivery months. Jiang \& Hayenga [26] also analyzed corn and soybean basis behavior and found that seasonal patterns, storage, and transportation costs, and production affect basis significantly. O'Brien [27] examined the impact of structural factors such as elevators' organizational form, local and regional supply-demand situations, storage and handling capacity of grain elevators, the geographical proximity of competitive, non-affiliated elevators, and proximity to rail services on Kansas corn and wheat price differentials.

Some studies analyzed basis volatility and examined basis forecasting methods. Symeonidis et al. [28] and Gorton et al. [29] investigated the role of inventories in basis 
volatility and stated that lower inventory levels are associated with a wider futures basis. Mobarok [30] estimated spatiotemporal basis volatility and reported that temporal basis volatility is predominant in overall variation in North Dakota corn, soybean, and hard red spring wheat basis levels compared to volatility associated with elevator locations. Taylor et al. [31] compared various basis forecasting methods using the data on the deviation of basis from historical average for wheat, soybeans, corn, and grain sorghum in Kansas markets. They reported that the inclusion of such current market information improves post-harvest basis forecasts. Bekkerman et al. [32] evaluated the forecasting capabilities of northern US hard red spring and hard red winter basis models. They found that recent futures price, protein content, and harvest information are more important for accurate basis forecasts than historical basis averages.

Additionally, some studies focused on the implications of ethanol production for commodity basis relationship. Gallagher et al. [33] and McNew \& Griffith [34] reported that ethanol plants affect local grain prices. Fausti et al. [35] examined the relationship between ethanol production and corn basis volatility and reported that greater ethanol production strengthens local corn basis and increases basis volatility.

\subsection{Climate change- the missing link?}

An alternative pathway through which US agriculture could be affected is through the increased variability in origin basis behavior due to altered local supply and demand conditions and disrupted freight transportation and storage caused by aberrant climatic conditions. For example, droughts can affect vessel draft depth resulting in reduced barge loading capacity and impacting the shipping time and amount of grain transported from the upper Mississippi river basin to lower Mississippi river ports. Such disruptions could create 
a grain backlog leading to an increase in inventory being held by the local elevators and subsequently weakening local basis by widening the gap between cash and futures price. Volatile and unpredictable basis behavior is likely to worsen the commodity value chain as well as suppress producer income while at the same time raising buyers' costs and consequently increasing food, biofuel, and other related consumer prices. Therefore, it is imperative to analyze the link between climate change and commodity basis.

A significant amount of literature investigated the impact of weather anomalies on agricultural production and prices. Since commodity basis and cash price are closely linked, existing literature might give us clues regarding the relevance of climate extremes in determining commodity basis. Most of these studies indicate a statistically significant relationship between climate change variables and crop supply outcomes, thus reinforcing the significance of climate extremes in determining local cash and related futures price. For example, Mishra \& Cherkauer [36] found evidence of a significant correlation between drought index estimated from overserved precipitation and simulated runoff and soil moisture and US Midwest's corn and soybean yields. Miao et al. [37] estimated that, under different climate change scenarios, climate change negatively affects US corn and soybean supply. Haile et al. [38] evaluated the effect of climate change and reported that extreme growing season precipitation has a detrimental effect on global maize, wheat, rice, and soybean production. Vogel et al. [39] studied the impact of climate extremes on crop yields and reported evidence of a correlation between growing season temperature and precipitation extremes with global maize, soybeans, rice, and spring wheat yield anomalies. Climate extremes such as El Niño Southern Oscillation (ENSO) fluctuations have also been used to examine the impact of climate change on agricultural prices and production. 
Ubilava [40,41] found statistically significant linkages between climate anomaly associated with El Niño Southern Oscillation (ENSO) and agricultural commodity prices. Nam [42] examined how extreme climate events resulting from ENSO fluctuations affected the global commodity market and reported that climate uncertainty increases global commodity prices. Gutierrez [43] studied the effect of ENSO occurrences on wheat yields, export prices, stocks, and exports and documented a stronger, relatively negative impact of the cold phase of the Southern Oscillation cycle (La Niña) on wheat yield anomalies, exports, and stock-to-use ratios.

Since agricultural commodities acquire place and time utility by transportation, a review of the effect of climate change on transportation is also necessary. Several studies [44-46] indicated that extreme weather events such as precipitation and storm significantly impact the transportation system. Millerd [47] examined the effects of climate change on the Great lakes international shipping and concluded that a fall in lake's water level due to climate change would restrict vessel drafts, reduce vessel cargo, increase the number of trips and cargo moving costs. Caldwell et al. [48] reported that extreme weather events such as hurricanes, snowstorms, ice storms, floods are likely to decrease safety and increase the maintenance cost of the US freight transport system. Peterson et al. [49] stated that heavy precipitation events are increasing in the US and would adversely affect transportation infrastructure.

The literature review suggests that most climate change discussions concerning agricultural commodities tend to focus on long-run impacts on production, supply and demand fluctuations, freight transportation, and prices. There have been little to no discussions on the possible impact of short-term, extreme weather events on the commodity 
basis. In this study, we augment and update current literature by capturing the effect of different precipitation variables as well as their nonlinear interactions with Missouri corn and soybean basis.

\section{Methods}

\subsection{Conceptual framework}

For the purpose of this study, we consider the temporal component of corn and soybean basis, defined as:

$$
b_{i t}=p_{i t}-f_{i t}
$$

where $p_{i t}$ is the local price of corn/soybean and $f_{i t}$ is the price of nearby Chicago Board of Trade (CBOT) futures delivery contract.

Given the aim of this research, basis is modeled as a function of different precipitation variables, namely, local, growing season, and regional precipitation, while controlling for the effect of barge rate, diesel price, and ethanol intensity measure. Average temperature across Midwestern US has risen [5,50]. However, shifts in precipitation pattern, by contrast, pose most damaging threat to agriculture as most corn and soybean in the midwestern US are grown under rainfed conditions $[51,52]$. Therefore, we assume that the variation in corn and soybean production- an important determinant of local cash price, is likely to be linked to variation in precipitation during the grain-filling period. We also do not include ENSO phenomenon as there is weak evidence regarding the effect of such weather anomalies on the growing conditions of the US Midwest [53,54].

We use ethanol intensity measure, barge rate, and diesel price to capture the effect of ethanol production, river, and other non-river transportation costs, respectively. 


\subsection{Empirical framework}

The empirical analysis is based on an unbalanced panel dataset with data available at the grain elevator and local weather station level. We consider the following two-way fixed effects model:

$$
b_{i t}=X_{i t} \beta+u_{i}+r_{t}+\varepsilon_{i t}, \quad i=1, \ldots, N ; t=1, \ldots, T,
$$

where $b_{i t}$ is weekly average commodity basis quoted by elevator $i$ in period $t, X_{i t}$ is a vector of time-variant covariates measuring local, growing season, and regional precipitation and their quadratic terms, ethanol intensity measure, St. Louis segment barge rate, weekly average diesel price, and the interaction between port distance and the regional precipitation variables; $u_{i}$ and $r_{t}$ are unobserved elevator specific and time-fixed effects, respectively, and $\varepsilon_{i t}$ is the idiosyncratic error assumed to be independent and identically distributed (i.i.d.).

Local precipitation captures the immediate effect of normal or abnormal weekly rainfall on the local basis. Growing season precipitation is intended to capture the local supply effect. We fix the growing season to months June through August for corn and soybean. We hold the cumulative average of the growing season constant until the start of next year's growing season, assuming little to no additional effect of precipitation on local production after the growing season ends. Regional rainfall is one of the significant sources of flooding on the Mississippi River and its major tributaries [55]. Therefore, regional precipitation, proxied by a 3-month moving average of corn belt precipitation, aims to capture the effect of freight transportation disruptions on the local basis. To allow for the possible nonlinear influence of weather variables on basis levels, following the convention in the literature $[37,38,56]$, we model the climate variables with linear and quadratic terms. 
We also allow the interaction between corn belt precipitation variables and distance measures ${ }^{1}$ to see whether the effect changes for points father north or south relative to the Mississippi gulf.

The quadratic nature of the precipitation variables could make parameter estimates' interpretation tricky. For straightforward comparison across models and variables, we employ average marginal effect (AME) estimate. AME is more appropriate than marginal effect at means (MEM) as it reflects the full distribution of an independent variable [57]. We calculate the AME by using the actual observed values of the covariates and then averaging the estimated partial effects. Following Bartus [58], AME can be defined as:

$$
A M E=\beta_{i} \frac{1}{n} \sum_{m=1}^{n} f\left(\beta x^{m}\right),
$$

where $\beta x^{m}$ is the linear combination of parameters and variables for the $m^{\text {th }}$ observation.

We are aware of the potential impact that the different intensities of precipitation could have on barge rate. Barge rates are expected to be affected by the demand for downbound shipment of grain from the origin point. Since precipitation can affect the local grain production and demand for grain shipment, barge demand could derive from the good or bad harvest affected by the different intensities of precipitation. Therefore, the barge rate variable may not be exogenous, and a simultaneity bias may occur. To avoid biased and inconsistent estimates, we resort to two-stage fixed effect (FE-2SLS) estimation. We employ such estimation technique only for the model where barge rate is endogenous.

Since barge rate could be endogenous, identification requires finding at least one instrumental variable, which is exogeneous and uncorrelated with the residual term in the

\footnotetext{
${ }^{1}$ We estimate the straight-line north-south distance (as crow flies) that an elevator is from the port of New Orleans, Louisiana.
} 
basis equation. The instrumental variables selected include S\&P 500 index, U.S. merchandise exports, and U.S. Dollar index. The S\&P 500 index is used as a proxy for improved general economic conditions that could drive the demand for non-agricultural barge freight transportation; the U.S. Dollar index (trade-weighted average of major currencies) and U.S. merchandise exports are used as demand shifters, which satisfies the exogeneity requirement essential for our case.

\subsection{Data}

Data for this research are obtained from a variety of disparate sources. Basis and precipitation data are collected from the dedicated server of refinitiv and National Oceanic and Atmospheric Administration (NOAA), using an application programming interface (API). Transportation data (barge rate and diesel price) were obtained from USDA's Agricultural Transportation Open Data Platform. The data spans the range between January 2010 and October 2020.

As can be seen in Figures 1 and 2, corn and soybean production in Missouri is primarily concentrated in the northern half of the state and the boot heel region. This is mainly due to the mountainous terrain of south-central region which makes it unsuitable for agricultural production. The average weekly basis (Figure $3 \& 4$ ) is then estimated from the daily corn and soybean basis quoted by 151 elevators situated across Missouri. 


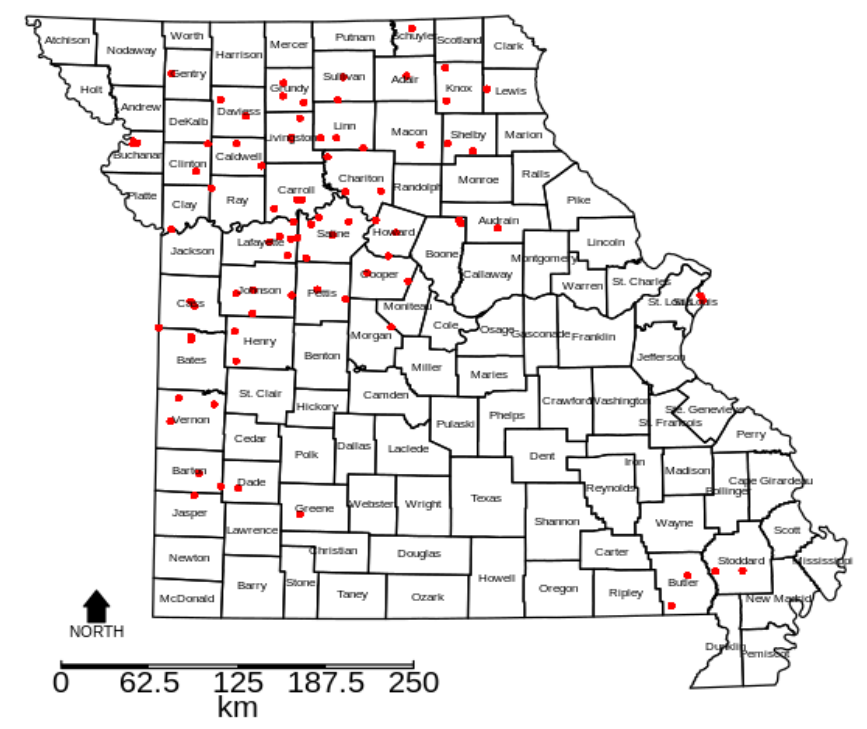

Figure 1. Corn elevator locations

Soybean elevator location

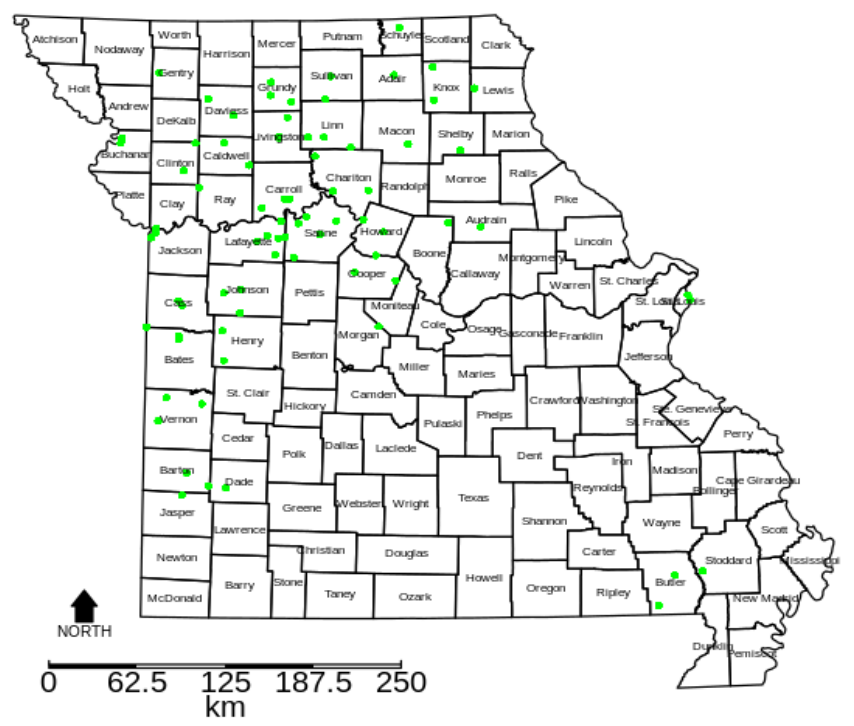

Figure 2. Soybean elevator locations 


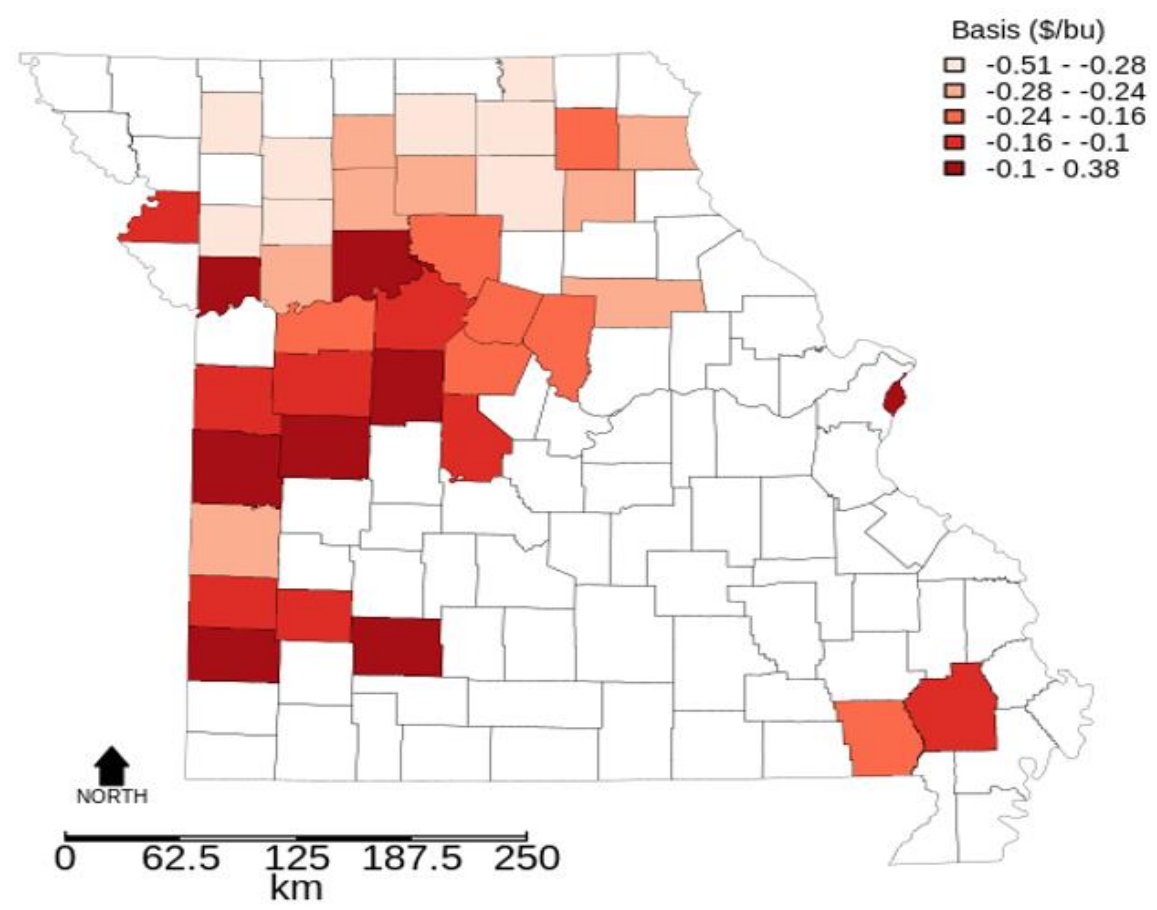

Figure 3. Corn basis map

Soybean basis map

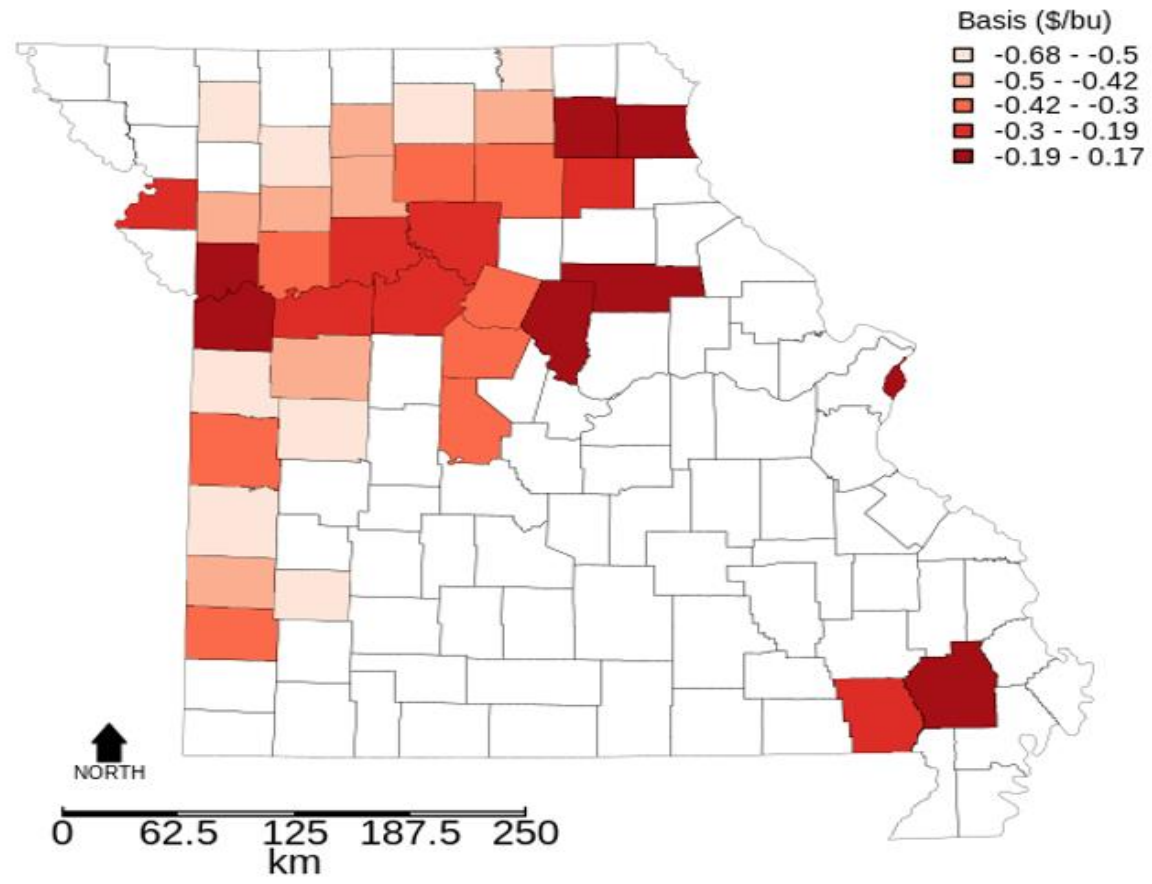

Figure 4. Soybean basis map 
We also estimate average weekly local precipitation (Figure $5 \& 6$ ) using the daily precipitation amounts recorded and reported by 1,112 weather stations positioned across the state.

\section{Precipitation map - Corn}

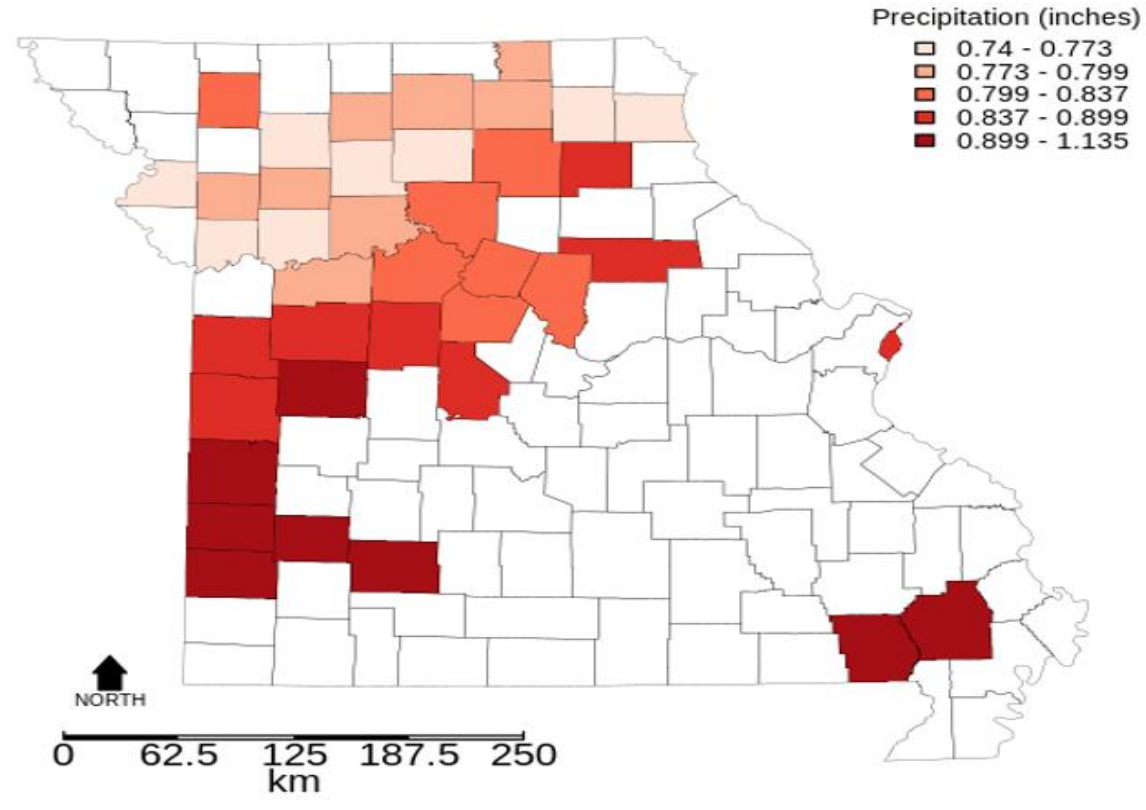

Figure 5. Local precipitation map- weather stations around corn elevators

Precipitation map - Soybean

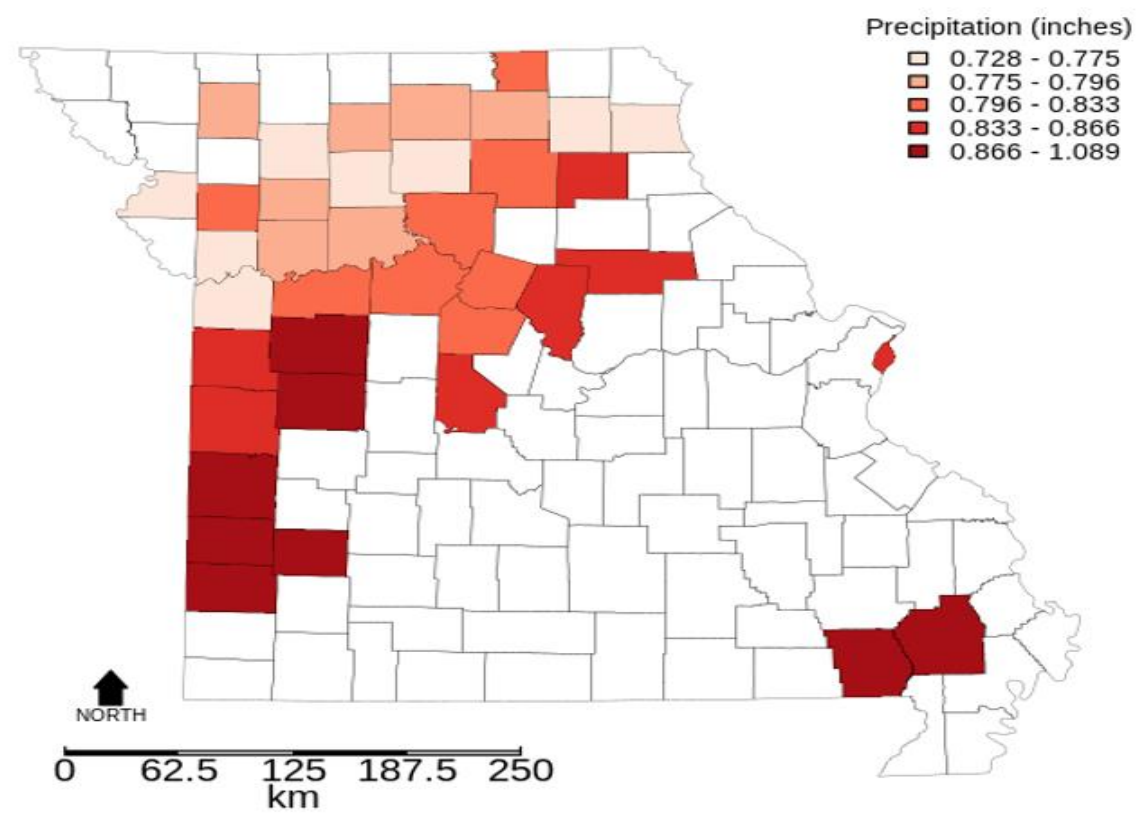

Figure 6. Local precipitation map- weather stations around soybean elevators 
Stations that do not report precipitation consistently through the sample period for the growing season are excluded from the analysis to minimize potential estimation bias. We assume that an elevator will likely receive its grain from a 30-mile radius. Therefore, we filtered out weather stations that are farther than 30 miles from the respective elevator's location.

The summary statistics are provided in Table 1.

Table 1. Descriptive statistics of the study variables

\begin{tabular}{|c|c|c|c|c|c|c|c|c|c|}
\hline \multirow[b]{2}{*}{ Variable } & \multirow[b]{2}{*}{ unit } & \multicolumn{4}{|c|}{ Corn } & \multicolumn{4}{|c|}{ Soybean } \\
\hline & & Mean & $\begin{array}{l}\text { Std. } \\
\text { Dev. }\end{array}$ & Min & Max & Mean & $\begin{array}{l}\text { Std. } \\
\text { Dev. }\end{array}$ & Min & Max \\
\hline Basis & $\$ / b u$ & -0.18 & 0.30 & -1.42 & 1.83 & -0.33 & 0.44 & -1.5 & 2.97 \\
\hline $\begin{array}{l}\text { Local } \\
\text { precipitation }\end{array}$ & inches & 0.83 & 1.07 & 0.00 & 10.39 & 0.82 & 1.07 & 0.00 & 10.39 \\
\hline $\begin{array}{l}\text { Growing } \\
\text { season } \\
\text { precipitation }\end{array}$ & inches & 1.11 & 0.50 & 0.00 & 5.36 & 1.10 & 0.48 & 0.00 & 5.36 \\
\hline $\begin{array}{l}\text { Corn belt } \\
\text { precipitation }\end{array}$ & inches & 2.97 & 1.18 & 1.08 & 5.78 & 2.96 & 1.18 & 1.08 & 5.78 \\
\hline Barge rate & $\$ /$ ton & 12.82 & 4.97 & 6.08 & 41.23 & 12.85 & 4.98 & 6.08 & 41.23 \\
\hline Diesel price & \$/gallon & 3.10 & 0.61 & 1.91 & 4.15 & 3.11 & 0.62 & 1.91 & 4.15 \\
\hline $\begin{array}{l}\text { Ethanol } \\
\text { intensity }\end{array}$ & $\begin{array}{l}000 \\
\text { gallons/sq. } \\
\mathrm{km}\end{array}$ & 4.02 & 2.87 & 0.00 & 11.32 & 4.02 & 0.45 & 0.00 & 11.32 \\
\hline $\begin{array}{l}\text { Distance to } \\
\text { NOLA }\end{array}$ & $100 \mathrm{~km}$ & 10.17 & 0.95 & 7.34 & 11.75 & 10.20 & 0.93 & 7.34 & 11.75 \\
\hline $\begin{array}{l}\text { US Dollar } \\
\text { index }\end{array}$ & index & 90.31 & 9.37 & 73.94 & 108.19 & 89.96 & 9.41 & 73.94 & 108.19 \\
\hline S\&P 500 & index & 2043.77 & 644.81 & 1022.58 & 3709.41 & 2067.94 & 647.19 & 1022.58 & 3709.41 \\
\hline $\begin{array}{l}\text { US } \\
\text { merchandise } \\
\text { export }\end{array}$ & $\begin{array}{l}\text { billion } \\
\text { dollars }\end{array}$ & 108.86 & 9.67 & 77.45 & 127.40 & 108.81 & 9.64 & 77.45 & 127.40 \\
\hline
\end{tabular}

The weekly mean corn and soybean basis is negative, indicating local cash price lies mostly under the CBOT futures price, and Missouri is a corn and soybean surplus region. Corn basis appears to be less volatile than soybean when compared based on the standard deviation. This implies that stylized facts such as storage, trade, and transportation have a more exacerbating effect on soybean demand and supply. On the other hand, among the weather variables, corn belt precipitation seems most volatile if assessed by the same 
criteria. Barge rates have a relatively high standard deviation when compared to diesel price, indicating frequent higher than the normal price for downbound freight originating from St. Louis. Ethanol intensity ${ }^{2}$ is used as a proxy to capture the exogenous effect of local demand for corn on basis levels. It is a kernel density function-based measure that uses the nameplate capacity of ethanol plants located near the elevators in our sample.

\section{Results}

We estimate the FE-2SLS and FE model for corn and soybean, respectively. The model FE-2SLS accounts for the endogeneity of barge rate and minimizes potential simultaneity bias in the estimation procedure. We also estimate the average marginal effect by averaging the partial effect of each observed value of an independent variable. The diagnostics are reported in the lower part of Table 2. First, we test the null hypothesis that barge rate can actually be treated as exogenous. The endogeneity test that we implement here is numerically identical to a Hausman test under the assumption of conditional homoskedasticity [59]. We reject the null in the corn basis model suggesting FE estimates are inconsistent.

On the other hand, in the soybean model, we fail to reject the null, implying the barge rate variable is not endogenous and, consequently, the FE model yields unbiased estimates. Next, for the corn model, we report the Anderson's canonical correlation LM statistic, Cragg-Donald statistic, and Sargan's statistic, which are the results of tests for underidentification, weak identification, and overidentification, respectively. The test results, shown in the lower half of Table 2, indicate that in the corn model, excluded instruments are properly excluded and sufficiently correlated with the barge rate. The test

\footnotetext{
${ }^{2}$ This variable is estimated by Vince Breneman (OCE, USDA).
} 
for overidentification, using the Sargan's statistic shows that we cannot reject the joint null hypothesis that instruments are valid and correctly excluded from the estimated equation. Therefore, the results from the FE-2SLS model are consistent.

Table 2. Effect of precipitation variables on basis

\begin{tabular}{|c|c|c|c|c|}
\hline \multirow[t]{2}{*}{ Variables } & \multicolumn{2}{|c|}{ Corn } & \multicolumn{2}{|c|}{ Soybean } \\
\hline & 2SLS-FE & $\begin{array}{r}\text { Average } \\
\text { marginal } \\
\text { effect }\end{array}$ & $\mathrm{FE}$ & $\begin{array}{r}\text { Average } \\
\text { marginal } \\
\text { effect }\end{array}$ \\
\hline Local precipitation & $\begin{array}{l}-0.006^{* *} \\
(0.003)\end{array}$ & $\begin{array}{l}-0.003 \\
(0.002)\end{array}$ & $\begin{array}{l}0.012 * * * \\
(0.004)\end{array}$ & $\begin{array}{l}0.008 * * * \\
(0.003)\end{array}$ \\
\hline Local precipitation ${ }^{2}$ & $\begin{array}{l}0.002 * * * \\
(0.001)\end{array}$ & & $\begin{array}{l}-0.002 * * \\
(0.001)\end{array}$ & \\
\hline Growing season precipitation & $\begin{array}{l}-0.190 * * * \\
(0.007)\end{array}$ & $\begin{array}{l}-0.111 * * * \\
(0.003)\end{array}$ & $\begin{array}{l}-0.289 * * * \\
(0.028)\end{array}$ & $\begin{array}{l}-0.082 * * * \\
(0.011)\end{array}$ \\
\hline Growing season precipitation ${ }^{2}$ & $\begin{array}{l}0.035^{* * * *} \\
(0.002)\end{array}$ & & $\begin{array}{l}0.094 * * * \\
(0.011)\end{array}$ & \\
\hline Corn belt precipitation & $\begin{array}{l}0.012 \\
(0.067)\end{array}$ & $\begin{array}{l}0.044 * * * \\
(0.001)\end{array}$ & $\begin{array}{l}-0.039 \\
(0.123)\end{array}$ & $\begin{array}{l}0.062 * * * \\
(0.003)\end{array}$ \\
\hline Corn belt precipitation ${ }^{2}$ & $\begin{array}{l}0.002 \\
(0.010)\end{array}$ & & $\begin{array}{l}0.012 \\
(0.021)\end{array}$ & \\
\hline Corn belt precipitation*distance & $\begin{array}{l}-0.002 \\
(0.007)\end{array}$ & & $\begin{array}{l}-0.022 * \\
(0.012)\end{array}$ & \\
\hline Corn belt precipitation ${ }^{2 *}$ distance & $\begin{array}{l}0.001 \\
(0.001)\end{array}$ & & $\begin{array}{l}0.004 * * \\
(0.002)\end{array}$ & \\
\hline Ethanol intensity & $\begin{array}{l}0.039 * * * \\
(0.003)\end{array}$ & $\begin{array}{l}0.039 * * * \\
(0.003)\end{array}$ & $\begin{array}{l}-0.003 \\
(0.017)\end{array}$ & $\begin{array}{l}0.003 \\
(0.017)\end{array}$ \\
\hline Diesel price (dollars per gallon) & $\begin{array}{l}0.306 * * * \\
(0.005)\end{array}$ & $\begin{array}{l}0.306 * * * \\
(0.005)\end{array}$ & $\begin{array}{l}0.265 * * * \\
(0.010)\end{array}$ & $\begin{array}{l}0.265 * * * \\
(0.010)\end{array}$ \\
\hline Barge rate & $\begin{array}{l}-0.047 * * * \\
(0.001)\end{array}$ & $\begin{array}{l}-0.047 * * * \\
(0.001)\end{array}$ & $\begin{array}{l}-0.025^{* * * *} \\
(0.001)\end{array}$ & $\begin{array}{l}-0.025 * * * \\
(0.001)\end{array}$ \\
\hline Constant & $\begin{array}{l}-0.583^{* * * *} \\
(0.019)\end{array}$ & & $\begin{array}{l}-0.411^{* * * *} \\
(0.088)\end{array}$ & \\
\hline $\begin{array}{l}\text { Endogeneity test of endogenous } \\
\text { regressors (P-value) }\end{array}$ & 0.000 & & 0.1159 & \\
\hline $\begin{array}{l}\text { Under-identification test (Anderson } \\
\text { canon. corr. LM statistic) }\end{array}$ & 2745.739 & & & \\
\hline $\begin{array}{l}\text { Weak identification test (Cragg- } \\
\text { Donald Wald F statistic) }\end{array}$ & 988.895 & & & \\
\hline $\begin{array}{l}\text { Overidentification test ( } \mathrm{p} \text {-value of } \\
\text { Sargan statistic) }\end{array}$ & 0.140 & & & \\
\hline Observations & 36,794 & & 34,106 & \\
\hline R-squared (overall) & 0.234 & & 0.226 & \\
\hline
\end{tabular}


Results indicate that, the coefficients of local precipitation and squared local precipitation are statistically significant for both corn and soybean model. The findings imply that there exists a U-shaped or convex relationship between local precipitation and corn basis; that is, when local precipitation is lower than the inflection point of $1.5 \mathrm{inch}$, the increase in local precipitation weakens corn basis, and once it crosses that threshold level, increase in local precipitation strengthens the basis. Response of soybean basis is different from that of corn basis as the effect of local precipitation is positive with a decreasing rate, indicating an inverted U-shaped relationship. This implies that soybean basis strengthens as local precipitation increases and attains the maximum value at 3.25 inch (inflection point). After that, additional average weekly local precipitation accumulation will weaken the soybean basis. The AME estimates for corn basis is statistically insignificant and positive. Conversely, the statistically significant, positive AME estimate in soybean model indicates that a $1 \%$ increase in local precipitation will strengthen the soybean basis by 0.90 cents. Our analysis does not lend itself to empirically finding the source of the differences in corn and soybean model in terms of the sign and magnitude of local precipitation variables and AME estimates. However, such contrasts could be due to the variations in evapotranspiration demands during the various growth stages, and difference in market fundamentals such as local supply and demand, stock and storage, and marketing plan.

Growing season precipitation, on the other hand, exhibits U-shaped relationship in both models. The coefficients and associated AME measures are statistically significant at $1 \%$. The estimates show that basis keep weakening up to 2.71 and 1.54 inch of growing season precipitation accumulation for corn, and soybean, respectively, when both basis 
levels are at their minimum. The AME estimates suggest that for every $1 \%$ increase in growing season precipitation, corn and soybean basis will weaken by 11.1 and 8.1 cents, respectively. Intuitively, we would expect basis to be wider in response to a large local supply caused by a favorable growing season weather and opposite is expected in case of a tighter production situation. This is consistent with the literature that reported higher growing season precipitation improves corn and soybean production, whereas extreme growing season precipitation events have negative impact on production $(56,60,61)$.

The quadratic effect, along with the interaction influence of distance measures make direct interpretation of corn belt precipitation complicated. Hence, for an intuitive understanding, it is better to focus on the AME estimates rather than variable specific discussion. The AME estimates are significant at $1 \%$ level and imply that a $1 \%$ increase in corn belt precipitation will strengthen corn and soybean basis by 4.4 and 6.3 cents, respectively. This indicates that transportation disruptions are resulting in higher local price compared to futures prices, which is opposite of the findings reported by Hart \& Olson [62], who stated that transportation disruptions is associated with widening basis and falling local prices. One possible explanation could be use of alternate trade route (e.g., pacific northwest), transportation mode (e.g., truck, rail), or additional marketing opportunities (e.g., local ethanol production, soybean processing centers, wet corn milling) that absorb displaced barge traffic and bolster local demand- effectively strengthening the basis.

The results also indicate that the relationship between soybean basis and corn belt precipitation is statistically significant when port distance is considered, indicating uninterrupted access to export facilities impact local soybean market through smooth 
interregional trade and transportation linkage. One explanation could be, compared to corn, relatively large soybean export volume [13] and share of soybean export from Missouri via Mississippi gulf [63] are exerting influence and allowing soybean basis surface to adjust significantly. The signs of linear and quadratic terms also match the expectations. Negative linear term indicates that under normal weather condition which allows uninterrupted grain shipment along the river, basis would be less negative for southern elevators due to the difference in spatial arbitrage. Positive quadratic term suggests that the soybean basis would be stronger for northern elevators compared to southern elevators when flooding along the Mississippi river disrupts export-bound grain flow. Without any ability to confirm, we presume this could be due the fact that northern elevators have to ship through the south. Therefore, anything that affects the southern elevators for a while would affect the northern elevators as well but not the vice versa.

Among the control variables, the ethanol intensity measure positively affects corn basis, as expected, and is significant at a 5\% level. Corn basis strengthens by 3.9 cents with every thousand gallons/per sq. miles increase in ethanol intensity. This could be explained by the increased demand for nearby cash sales of corn due to the expanded ethanol intensity in the area surrounding the local elevator. Concerning the non-river transportation cost proxy, the coefficients for diesel price in both models are positive and statistically significant at $1 \%$ level, a finding that is contrary to theoretical expectations. A theoretical explanation of this result could be that the cost paid by the growers for shorter-haul shipment- delivery from farm to elevator location results in a higher local price. Another possible explanation could be that the diesel variable is picking up the effect of cash costs producers incur from using fuel for grain production, but this seems quite unlikely given 
the relationship between weekly diesel price and annual production costs as well as the scope for country-wide cost effects rather than locally distinct cost effects. The different barge and diesel price effects are difficult to explain in the end given that both are included to represent costs of transportation from local collection points to markets. The barge ratebasis relationship is statistically significant at a $1 \%$ level and has the expected negative sign in both models and consistent with other studies $[1,2,64]$ that reported similar findings.

\section{Conclusions}

Using an extensive panel dataset for the period from 2010 to 2020 and an empirical framework, we analyze the effect that precipitation variations have on Missouri corn and soybean basis. In particular, we examine the influence of local, growing season, and regional precipitation on corn and soybean basis. We document statistically significant linear and nonlinear basis responses in both corn and soybean models for local and growing season precipitation variations. We also find a statistically significant moderating effect of port distance measure on the curvilinearity of the association between regional precipitation and soybean basis. Correspondingly, we find that transportation disruptions and the interceding effects of port distance are not statistically significant for corn basis. One explanation could be the offsetting effect of local corn demand, boosted by ethanol production and livestock feeding operations, which are muting these impacts on corn basis. The average marginal effect of corn belt precipitation is, however, found to be statistically significant and positive in both corn and soybean model indicating a possible spurring effect of the alternative trade route and grain transportation mode on Missouri corn and soybean basis. It is important to note that we estimated the short-run determinants of basis which might not hold in the long-run as the estimates are sensitive to the future climate 
trajectory and any climate change policy framework that can influence market dynamics. Most climate models project that extreme precipitation events such as droughts and floods will increase in the US [5,65-67]. Previous studies have focused on the price and production effect of climate change and overlooked commodity basis. Commodity basis is an important market tool that reflects variability related to local supply and demand. Therefore, estimating the climatic effect on commodity basis and detecting threshold level for significant basis impact could facilitate informed grain marketing and selling decisions. Also, given the climate projections, there are legitimate concerns regarding precipitation's influence on future navigability of major transportation arteries that link Missouri to export facilities down the Mississippi river. Hence, the information generated in this research has even greater utility when studied in the context of the role barge freight transportation plays in the state's agriculture.

Although our models explain significant precipitation-related variation in corn and soybean basis, future research is warranted to predict the effect of alternative future climate change scenarios on the commodity basis. The focus of the current study is on Missouri corn and soybean which may limit the generalization of the findings for locations such as corn belt. Therefore, a more elaborate empirical framework, capable of capturing the regional climate induced basis variation is a likely improvement. However, even with the aforementioned limitations, the findings of this study can still be used to inform policies that aims at limiting adverse impact of climate change on state agriculture by planning and implementing appropriate adaptation strategies. 


\section{Reference}

1. McKenzie AM. The effects of barge shocks on soybean basis levels in Arkansas: A study of market integration. Agribusiness. 2005;21(1):37-52.

2. Wilson WW, Dahl BL. Grain Pricing and Transportation: Dynamics and Changes in Markets [Internet]. Agribusiness \& Applied Economics Report. North Dakota State University, Department of Agribusiness and Applied Economics; 2010 Dec. (Agribusiness \& Applied Economics Report). Report No.: 98202. Available from: https://ideas.repec.org/p/ags/nddaae/98202.html

3. Jiang B. Corn and soybean basis behavior and forecasting: fundamental and alternative approaches [Internet] [Doctor of Philosophy]. [Ames]: Iowa State University, Digital Repository; 1997. p. 6767104. Available from: https://lib.dr.iastate.edu/rtd/12214/

4. Garcia P, Good D. An Analysis of the Factors Influencing the Illinois Corn Basis, 1971-1981. In: Proceedings of the NCR-134 Conference on Applied Commodity Price Analysis, Forecasting, and Market Risk Management [Internet]. Des Moines, IA; 1983. Available from: https://ageconsearch.umn.edu/record/285381

5. Angel J, Swanston BM, Boustead KC, Conlon KR, Hall JL, Jorns KF, et al. Midwest. In: Reidmiller DR, C.W. Avery, D.R. Easterling, K.E. Kunkel, K.L.M. Lewis, T.K. Maycock, et al., editors. Impacts, Risks, and Adaptation in the United States: Fourth National Climate Assessment, Volume II. Washington, DC: U.S. Global Change Research Program; 2018. p. 872-940.

6. Dai S, Shulski MD, Hubbard KG, Takle ES. A spatiotemporal analysis of Midwest US temperature and precipitation trends during the growing season from 1980 to 2013. Int J Climatol. 2016;36(1):517-25.

7. Rosenzweig C, Tubiello FN, Goldberg R, Mills E, Bloomfield J. Increased crop damage in the US from excess precipitation under climate change. Glob Environ Change. 2002 Oct 1;12(3):197-202.

8. Deschênes O, Greenstone M. The Economic Impacts of Climate Change: Evidence from Agricultural Output and Random Fluctuations in Weather. Am Econ Rev. 2007 Mar;97(1):354-85.

9. Schlenker W, Roberts MJ. Nonlinear temperature effects indicate severe damages to U.S. crop yields under climate change. Proc Natl Acad Sci. 2009 Sep 15;106(37):15594-8.

10. Thompson W, Gerlt S, Campbell JE, Kueppers LM, Lu Y, Snyder MA. A Cost of Tractability? Estimating Climate Change Impacts Using a Single Crop Market 
Understates Impacts on Market Conditions and Variability. Appl Econ Perspect Policy. 2017;39(2):346-62.

11. Kaldor N. Speculation and Economic Stability. Rev Econ Stud. 1939;7(1):1-27.

12. Working H. Theory of the Inverse Carrying Charge in Futures Markets. J Farm Econ. 1948;30(1):1-28.

13. Missouri Department of Agriculture. Missouri Ag Highlights [Internet]. 2021. Available from: https://agriculture.mo.gov/topcommodities.php

14. Tomek WG. Commodity Futures Prices as Forecasts. Rev Agric Econ. 1997;19(1):23-44.

15. Brennan MJ. The Supply of Storage. Am Econ Rev. 1958;48(1):50-72.

16. Williams JC. The Economic Function of Futures Markets [Internet]. Cambridge: Cambridge University Press; 1986. Available from: https://www.cambridge.org/core/books/economic-function-of-futuresmarkets/3EF29E6B1947BB3C89272CC8B330A7C1

17. Fama EF, French KR. Commodity Futures Prices: Some Evidence on Forecast Power, Premiums, and the Theory of Storage. J Bus. 1987;60(1):55-73.

18. Fama EF, French KR. Business Cycles and the Behavior of Metals Prices. J Finance. 1988;43(5):1075-93.

19. Pirrong S, Haddock D, Kormendi RC. Grain Futures Contracts: An Economic Appraisal [Internet]. New York: Springer US; 1993. Available from: https://www.springer.com/gp/book/9780792393276

20. Adjemian M, Garcia P, Irwin S, Smith A. Non-Convergence in Domestic Commodity Futures Markets: Causes, Consequences, and Remedies. Washington, DC: United States Department of Agriculture, Economic Research Service; 2013 Aug. Report No.: EIB-115.

21. Irwin SH, Garcia P, Good DL, Kunda E. Poor Convergence Performance of CBOT Corn, Soybean and Wheat Futures Contracts: Causes and Solutions. Rochester, NY: Department of Agricultural and Consumer Economics, University of Illinois at Urbana-Champaign; 2009 Mar. (Marketing and Outlook Research Report). Report No.: 2009-02.

22. Irwin SH, Garcia P, Good DL, Kunda EL. Spreads and Non-Convergence in Chicago Board of Trade Corn, Soybean, and Wheat Futures: Are Index Funds to Blame? Appl Econ Perspect Policy. 2011;33(1):116-42. 
23. Aulerich NM, Fishe RPH, Harris JH. Why do expiring futures and cash prices diverge for grain markets? J Futur Mark. 2011;31(6):503-33.

24. Davis L, Hill L. Spatial Price Differentials for Corn among Illinois Country Elevators. Am J Agric Econ. 1974;56(1):135-44.

25. Thompson SR, Eales JS, Hauser RJ. An Empirical Analysis of Cash and Futures Grain Price Relationships in the North Central Region. North Cent J Agric Econ. 1990;12(2):241-54.

26. Jiang B, Hayenga M. Corn and soybean basis behavior and forecasting: fundamental and alternative approaches. In: Proceedings of the NCR-134 Conference on Applied Commodity Price Analysis, Forecasting, and Market Risk Management [Internet]. Chicago, IL; 1997. Available from: https://lib.dr.iastate.edu/rtd/12214/

27. O'Brien DM. The Effects of the Micro-Market Structure for Kansas Grain Elevators on Spatial Grain Price Differentials. In: 2009 Conference, April 20-21, 2009, St Louis, Missouri. St. Louis, MO; 2009.

28. Symeonidis L, Prokopczuk M, Brooks C, Lazar E. Futures basis, inventory and commodity price volatility: An empirical analysis. Econ Model. 2012 Nov 1;29(6):2651-63.

29. Gorton GB, Hayashi F, Rouwenhorst KG. The Fundamentals of Commodity Futures Returns. Rev Finance. 2013 Jan 1;17(1):35-105.

30. Mobarok MH. A Study of North Dakota Crop Basis Volatility: A Mixed Model Approach to Temporally and Spatially Analyze Unobserved Basis Determinants [Internet]. North Dakota State University; 2017. Available from: https://library.ndsu.edu/ir/handle/10365/28549

31. Taylor MR, Dhuyvetter KC, Kastens TL. Forecasting Crop Basis Using Historical Averages Supplemented with Current Market Information. J Agric Resour Econ. 2006;31(3):549-67.

32. Bekkerman A, Brester GW, Taylor M. Forecasting a Moving Target: The Roles of Quality and Timing for Determining Northern U.S. Wheat Basis. J Agric Resour Econ. 2016;17.

33. Gallagher P, Wisner R, Brubacker H. Price Relationships in Processors' Input Market Areas: Testing Theories for Corn Prices Near Ethanol Plants. Can J Agric Econ Can Agroeconomie. 2005;53(2-3):117-39.

34. McNew K, Griffith D. Measuring the Impact of Ethanol Plants on Local Grain Prices. Rev Agric Econ. 2005;27(2):164-80. 
35. Fausti SW, Link to external site this link will open in a new window, Bashir Q, Kelly MD. Does ethanol production affect corn basis volatility? Agric Finance Rev. 2017;77(4):506-23.

36. Mishra V, Cherkauer KA. Retrospective droughts in the crop growing season: Implications to corn and soybean yield in the Midwestern United States. Agric For Meteorol. 2010 Jul 15;150(7):1030-45.

37. Miao R, Khanna M, Huang H. Responsiveness of Crop Yield and Acreage to Prices and Climate. Am J Agric Econ. 2016;98(1):191-211.

38. Haile MG, Wossen T, Tesfaye K, von Braun J. Impact of Climate Change, Weather Extremes, and Price Risk on Global Food Supply. Econ Disasters Clim Change. 2017 Jun;1(1):55-75.

39. Vogel E, Donat MG, Alexander LV, Meinshausen M, Ray DK, Karoly D, et al. The effects of climate extremes on global agricultural yields. Environ Res Lett. 2019 May 3;14(5):054010.

40. Ubilava D. The ENSO Effect and Asymmetries in Wheat Price Dynamics. World Dev. 2017 Aug 1;96:490-502.

41. Ubilava D. The Role of El Niño Southern Oscillation in Commodity Price Movement and Predictability. Am J Agric Econ. 2018;100(1):239-63.

42. Nam K. Investigating the effect of climate uncertainty on global commodity markets. Energy Econ. 2021 Apr 1;96:105123.

43. Gutierrez L. Impacts of El Niño-Southern Oscillation on the wheat market: A global dynamic analysis. PLOS ONE. 2017 Jun 8;12(6):e0179086.

44. IPCC. Climate change 2007: the physical science basis: contribution of Working Group I to the Fourth Assessment Report of the Intergovernmental Panel on Climate Change. Cambridge; New York: Cambridge University Press; 2007.

45. Maoh H, Kanaroglou P, Woudsma C. Simulation Model for Assessing the Impact of Climate Change on Transportation and the Economy in Canada. Transp Res Rec. 2008 Jan 1;2067(1):84-92.

46. Savonis MJ, Burkett V, Potter JR. Impacts of climate change and variability on transportation systems and infrastructure: Gulf Coast study, phase I [Internet]. U.S. Climate Change Science Program; 2008. Available from: http://pubs.er.usgs.gov/publication/70203012

47. Millerd F. The potential impact of climate change on Great Lakes international shipping. Clim Change. 2011 Feb 1;104(3):629-52. 
48. Caldwell H, Quinn KH, Meunier J, Suhrbier J, Grenzeback L. The Potential Impacts of Climate Change on Transportation Potential Impacts of Climate Change on Freight Transport. U.S. Department of Transportation, Center for Climate Change and Environmental Forecasting; 2002.

49. Peterson TC, McGuirk M, Houston TG, Horvitz AH. Climate Variability and Change with Implications for Transportation. NOAA National Climatic Data Center; 2006 p. 146.

50. EPA. Climate change indicators in the United States, 2016. Fourth edition. U.S. Environmental Protection Agency; 2016 p. 96.

51. Hussain MZ, Hamilton SK, Bhardwaj AK, Basso B, Thelen KD, Robertson GP. Evapotranspiration and water use efficiency of continuous maize and maize and soybean in rotation in the upper Midwest U.S. Agric Water Manag. 2019 Jul 20;221:92-8.

52. Li Y, Guan K, Schnitkey GD, DeLucia E, Peng B. Excessive rainfall leads to maize yield loss of a comparable magnitude to extreme drought in the United States. Glob Change Biol. 2019;25(7):2325-37.

53. Glennie E, Anyamba A. Midwest agriculture and ENSO: A comparison of AVHRR NDVI3g data and crop yields in the United States Corn Belt from 1982 to 2014. Int J Appl Earth Obs Geoinformation. 2018 Jun 1;68:180-8.

54. Kellner O, Niyogi D. Climate Variability and the U.S. Corn Belt: ENSO and AO Episode-Dependent Hydroclimatic Feedbacks to Corn Production at Regional and Local Scales. Earth Interact. 2015 Jun 1;19(6):1-32.

55. Galloway G. USA: flood management-Mississippi River. Geneva, Switzerland: World Meteorological Organization (WMO); 2004 p. 12. (Integrated flood management case study).

56. Westcott PC, Jewison M. Weather Effects on Expected Corn and Soybean Yields. Washington, DC: Economic Research Service, USDA; 2013. Report No.: FDS-13g01 .

57. Leeper TJ. Interpreting Regression Results using Average Marginal Effects with R's margins [Internet]. 2018 p. 32. Available from: https://CRAN.Rproject.org/package $=$ margins

58. Bartus T. Estimation of marginal effects using margeff. Stata J. 2005;5(3):309-29.

59. Hayashi F. Econometrics. Princeton NJ: Princeton University Press; 2000. 
60. Chen C-C, McCarl BA, Schimmelpfennig DE. Yield Variability as Influenced by Climate: A Statistical Investigation. Clim Change. 2004 Sep 1;66(1):239-61.

61. Goldblum D. Sensitivity of Corn and Soybean Yield in Illinois to Air Temperature and Precipitation: The Potential Impact of Future Climate Change. Phys Geogr. 2009 Jan 1;30(1):27-42.

62. Hart C, Olson F. Analysis of Grain Basis Behavior During Transportation Disruptions and Development of Weekly Grain Basis Indicators for the USDA Grain Transportation Report [Internet]. Ames, Iowa: Center for Agricultural and Rural Development, Iowa State University; 2017 May. Report No.: CARD Staff Reports. 82. Available from: https://lib.dr.iastate.edu/card_staffreports/82

63. Soy Transportation Coalition. Soybean exports by port region [Internet]. 2021. Available from: https://www.soytransportation.org/stats.html

64. Hailu G, Maynard A, Weersink A. Empirical analysis of corn and soybean basis in Canada. Appl Econ. 2015 Nov 2;47(51):5491-509.

65. Easterling DR, Arnold JR, Knutson T, Kunkel KE, LeGrande AN, Leung LR, et al. Precipitation Change in the United States [Internet]. Washington, DC: U.S. Global Change Research Program; 2017. (Climate Science Special Report: Fourth National Climate Assessment). Available from: https://science2017.globalchange.gov/chapter/7/

66. Kirchmeier-Young MC, Zhang X. Human influence has intensified extreme precipitation in North America. Proc Natl Acad Sci. 2020 Jun 16;117(24):13308-13.

67. Swain DL, Wing OEJ, Bates PD, Done JM, Johnson KA, Cameron DR. Increased Flood Exposure Due to Climate Change and Population Growth in the United States. Earths Future. 2020;8(11):e2020EF001778. 


\section{Vita}

I do not have much to say about me. I am an ordinary man with medium level intellect and very big ambition. I knew that if I can work hard and be honest, I can amount to something in this great country. I was born in a very poor family in Bangladesh. My mother, despite being illiterate, did understood the importance of education and fought courageously against all odds to make sure that her three children get a good education. From the very early age, I wanted to make my parents proud and happy. This terminal degree is my way of honoring my parents for all the sacrifices they made for me and my siblings. I know that this achievement is just the beginning, the night is still young and there are many more to achieve. In the words of Robert Frost- The woods are lovely, dark and deep/ But I have promises to keep/And miles to go before I sleep/And miles to go before I sleep. 